ESCOLA DE ENGENHARIA DE SÃO CARLOS

INSTITUTO DE FISICA DE SÃO CARLOS

INSTITUTO DE QUÍMICA DE SÃO CARLOS

\title{
ESTUDO DE ADESIVOS SENSÍVEIS À PRESSÃO CONSTITUÍDOS POR COMPOSTOS ELASTOMÉRICOS
}

FERNANDO PELLICANO

Dissertação apresentada à Área de Interunidades em Ciências e Engenharia de Materiais, da Universidade de São Paulo, como parte dos requisitos para obtenção do Título de Mestre em Ciências e Engenharia de Materiais.

Orientador: Prof. Dr. Osvaldo Novais de Oliveira Jr.

USP/IFSC/SBI

São Carlos

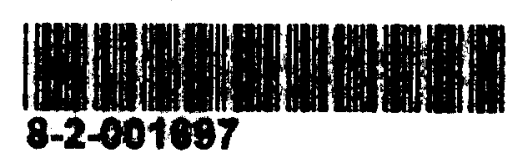




Pellicano, Fernando
“Estudo de adesivos sensíveis à pressão constituídos por compostos elastoméricos”
Fernando Pellicano - São Carlos, 2005
Dissertação (Mestrado) - Interunidades Ciência e Engenharia de Materiais da
Universidade de São Paulo, 2005 - páginas: 122
Área: Interunidades Ciência e Engenharia de Materiais
Orientador: Prof. Dr. Osvaldo Novais de Oliveira Júnior
1. Compostos elastoméricos
1. Título


MEMBROS DA COMISSÃO JULGADORA DA DISSERTAÇĀO DE MESTRADO DE FERNANDO PELLICANO, APRESENTADA À ÁREA INTERUNIDADES CIÉNCIA E ENGENHARIA DE MATERIAIS, UNIVERSIDADE DE SÃO PAULO, EM 20/04/2005.

COMISSÃO JULGADORA:

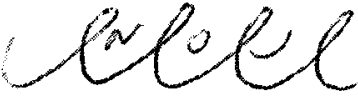

Prof. Dr. Osvaldo Novais de Oliveira Júnior (Orientador e Presidente) - IFSC/USP

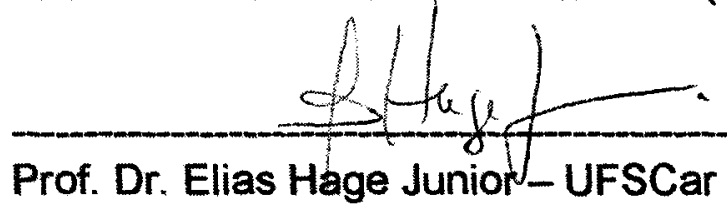

Ane Main SPlépes

Profa. Dra. Ana Maria de Guzzi Plepis - IQSC/USP 
Aos meus pais Antonio e Sueli pela oportunidade e sacrificios. 
$>$ Ao meu orientador Dr. Osvaldo Novais de Oliveira Junior, pelo apoio, paciência e os excelentes direcionamentos propostos em todas as etapas deste trabalho.

> Ao Dr. Valtencir Zucolotto do Grupo de Polímeros pertencente ao departamento Interunidades da USP/ São Carlos, pela colaboração na realização de espectroscopias.

D $3 \mathrm{M}$ do Brasil, pelo suporte dado à execução deste trabalho e fornecimento dos materiais.

$>$ Sinceros agradecimentos ao Benedito A. dos Santos, Aileen N. Fowler e Jose Humberto Lopes pela amizade, orientação, discussões e utilização dos equipamentos do laboratório técnico de produtos elétricos da empresa 3M do Brasil.

$>$ Agradeço ao Euclides C. Ribeiro do laboratório técnico de produtos elétricos da empresa $3 \mathrm{M}$ do Brasil pela ajuda no processamento dos materiais.

> Aos amigos da $3 \mathrm{M}$ do Brasil: Neto, Catão, Gustavo, Telmo, André, Andressa, Helena, Milano, AC, Patrícia, Eduardo, Simone, pela amizade desprendida em todos esses anos.

A minha família, especialmente aos meus pais e irmãos, pelo incentivo, compreensão e convivência.

Agradeço a todos aqueles que direta e indiretamente contribuíram para a realização deste trabalho. 
LISTA DE FIGURAS

LISTA DE TABELAS

RESUMO

ABSTRACT

1 INTRODUÇÃO

2 REVISÃO BIBLIOGRÁFICA

2.1 História dos adesivos 4

2.2 Materiais utilizados nos adesivos 5

2.3 Vantagens e desvantagens dos adesivos 6

2.4 Uso de adesivos no mundo 8

2.5 Classificação dos adesivos $\quad 9$

2.6 Introdução a adesivos sensíveis à pressão 10

2.7 História dos adesivos sensíveis à pressão 12

2.8 Teoria da adesão 13

2.9 Tipos de esforços suportados pelos adesivos $\quad 21$

2.10 Materiais mais utilizados na composição de PSA 23

2.10.1 Borrachas 23

2.10.1.1 Borracha Natural 24

2.10.1.2 Borracha Sintética $\quad 28$

2.10.2 Antioxidante 32

2.10.3 Tatificantes 33

2.10.3.1 Breu 33

2.10.3.2 Resina hidrocarbônica 34

2.10.3.2 Resina hidrocarbônica aromática $\quad 35$

2.10.3.2 Resina hidrocarbônica alifática 35

2.10.3.3 Resina terpenica $\quad 36$

2.10.3.3 Escolha do tatificante $\quad 37$

2.10.4 Resinato de Zinco 39

2.10.5 Resina fenólica $\quad 40$

2.10.6 Cargas 40

2.10.7 Solventes $\quad 41$

2.11 Método de Processamento 43

2.11.1 Mastigação da borracha e incorporação de aditivos $\quad 43$

2.11.1.1 Moinho de dois rolos $\quad 44$

2.11.1.2 Misturador Interno $\quad 45$

2.11.2 Mistura e dissolução $\quad 47$

2.11.2.1 Batedeira $\quad 48$

2.11.2.2 Batedeira planetária $\quad 48$

2.11.2.3 Reator $\quad 49$

2.11.2.4 Misturador tipo sigma $\quad 50$ 
3 MATERIAIS E MÉTODOS UTILIZADOS 51

3.1 Materiais utilizados 51

3.2 Processamentos utilizados 52

3.2.1 Mastigação das borrachas $\quad 52$

3.2.2 Mistura e dissolução

3.2.3 Nivel da reação

3.2.4 Codificação dos experimentos 54

3.3 Métodos 54

3.3.1 Preparação dos corpos de prova $\quad 54$

3.3.2 Viscosidade $\quad 60$

3.3.3 Percentual de materiais sólidos $\quad 63$

3.3.4 Ancoragem 65

3.3.5 Resistência ao cisalhamento $\quad 68$

3.3.6 Grau de ligações cruzadas $\quad 70$

$\begin{array}{ll}\text { 3.3.7 Adesão } & 72\end{array}$

3.3.7.1 Aderência em superfície metálica $\quad 72$

3.3.7.2 Aderência em substrato vinílico $\quad 75$

$\begin{array}{ll}\text { 3.3.8 Fluência sob cisalhamento } & 79\end{array}$

3.3.9 Cromatografia de permeação em gel (GPC) 81

3.3.10 Espectroscopia no infravermelho (FTIR)

4 RESULTADOS E DISCUSSĀO $\quad 87$

$\begin{array}{ll}4.1 \text { Viscosidade } & 87\end{array}$

4.2 Percentual de materiais sólidos 88

4.3 Ancoragem do adesivo no dorso de PVC 91

4.4 Resistência ao cisalhamento 93

4.5 Grau de ligaçōes cruzadas $\quad 94$

4.6 Adesão 97

4.6.1 Adesão em superfície metálica 97

4.6.2 Adesão em substrato vinílico 99

4.6.3 Discussões dos resultados de adesão 101

4.7 Fluência sob cisalhamento ("Shear-Creep") 103

4.8 Cromatografia de permeaçăo em gel (GPC) 104

4.9 Espectroscopia no infravermelho com transformada Fourier 108

4.10 Estrutura química 111

5 CONCLUSÃO FINAL $\quad 114$

- 6 SUGESTÓES PARA TRABALHOS FUTUROS 118

7 REFERÊNCIAS BIBLIOGRAFICAS $\quad 119$

8 GLOSSÁRIO 121 
Figura 01 - Distribuição do mercado mundial de adesivos $\quad \mathbf{8}$

Figura 02 - llustração do mecanismo de intertravamento mecânico

Figura 03 - Ilustração da teoria de interação eletrostática $\quad 15$

Figura 04 - llustração do mecanismo de adsorção 16

Figura 05 - Ilustração do ângulo de contato 17

Figura 06 - llustração de boa "molhabilidade" apresentada por um adesivo 18

Figura 07 - llustração de "Molhabilidade" fraca apresentada por um adesivo 18

Figura 08 - llustração da teoria da adsorção química $\quad 19$

Figura 09 - llustração da teoria da difusão $\quad 20$

Figura 10 - llustração de um esforço compressivo 21

Figura 11 - Ilustração de um esforço cisalhante $\quad 21$

Figura 12 - llustração de um esforço sob tensão 12

Figura 13 - llustração de um esforço sob destacamento 12

Figura 14 - llustração de um esforço do tipo fissura 23

Figura 15 - Fórmula quimica da borracha natural (cis-1,4-poliisopreno) 25

Figura 16 - Distribuição da produção mundial de borracha natural ${ }^{(7)} \quad 26$

Figura 17 - Distribuição da produção mundial de borracha natural (7) 26

Figura 18 - Distribuição do consumo mundial de borracha natural (7) 27

Figura 19 - Distribuição do consumo mundial de borracha natural ${ }^{\text {() }}{ }^{27}$

Figura 20 - llustração da formação de radicais livres 28

Figura 21 - Distribuição da produção mundial de borracha sintética ${ }^{(7)} \quad 30$

Figura 22 - Distribuição da produção mundial de borracha sintética ${ }^{(7)} \quad 30$

Figura 23 - Distribuição do consumo mundial de borracha sintética ${ }^{(7)} 31$

Figura 24 - Distribuição do consumo mundial de borracha sintética ${ }^{(7)} 31$

Figura 25 - Resinas tatificantes aromáticas $\quad 35$

Figura 26 - Resinas tatificantes alifáticas $\quad 36$

Figura 27 - Resinas tatificantes terpênicas $\quad 37$

Figura 28 - Gráfico do efeito da quantidade de tatificante na propriedade de tato $\quad 37$

Figura 29 - Gráfico do efeito da quantidade de tatificante em tato, adesão e coesão $\quad 39$

Figura 30 - llustração de um moinho de dois rolos $\quad 44$

Figura 31 - Foto ilustrativa de um moinho de dois rolos $\quad 45$

Figura 32 - llustração de um misturador interno $\quad 46$

Figura 33 - Foto ilustrativa de um misturador interno $\quad 46$

Figura 34 - Foto ilustrativa de uma batedeira $\quad 48$

Figura 35 - Foto ilustrativa de uma batedeira planetária $\quad 49$

Figura 36 - Foto ilustrativa de um reator $\quad 49$

Figura 37 - Foto ilustrativa de um misturador tipo sigma $\quad 50$ 
Figura 38 - Montagem para revestimento de substrato com adesivo 55

Figura 39 - Exemplo de um gráfico tipo "Boxplot" 56

Figura 40 - Gráfico "Boxplot" dos valores da camada de adesivo revestida em PVC $\quad 57$

Figura 41 - Gráfico "Boxplot" dos valores da camada de adesivo revestida em Poliéster 58

Figura 42 - Efeito da camada de adesivo nos valores de adesão 59

Figura 43 - llustração do revestimento tipo cascata 61

Figura 44 - llustração da montagem efetuada para determinação da viscosidade $\quad 63$

Figura 45 - llustração da montagem efetuada para determinação do teor de sólidos $\quad 65$

Figura 46 - llustração da vista lateral da montagem realizada para ensaio de ancoragem 67

Figura 47 - llustração superior da montagem realizada para ensaio de ancoragem $\quad 67$

Figura 48 - llustraçáo da montagem ensaio de resistência ao cisalhamento 70

Figura 49 - Ilustração da montagem para determinação do grau de ligações cruzadas 71

Figura 50 - llustração do rolete utilizado nos ensaios de adesão 73

Figura 51 - llustração da máquina de tração utilizada para os ensaio de adesão $\quad 74$

Figura 52 - llustração da montagem do corpo de prova para ensaio de adesão ao dorso 77

Figura 53 - llustração da montagem para adesão ao dorso após exposição ao calor 78

Figura 54 - llustração do reômetro de torque de placas paralelas $\quad 80$

Figura 55 - Exemplo de uma curva de reometria shear-creep do tipo placas paralelas 81

Figura 56 - Gráfico da viscosidade Brookfield $\quad 88$

Figura 57 - Gráfico do percentual de sólidos $\quad 89$

Figura 58 - Gráfico do percentual de sólidos versus a viscosidade Brookfield 90

Figura 59 - Gráfico dos valores de ancoragem $\quad 92$

Figura 60 - Gráfico dos valores de ancoragem após exposição ao calor 92

Figura 61 - Gráfico da resistência ao cisalhamento $\quad 94$

Figura 62 - Gráfico do grau de ligações cruzadas $\quad 97$

Figura 63 - Gráfico dos valores de adesão em superfície metálica 98

Figura 64 - Gráfico dos valores de adesão ao dorso 100

Figura 65 - Gráfico dos ensaios de reometria placa paralela 103

Figura 66 - Exemplo do resultado do GPC 105

Figura 67 - Gráfico do resultado do GPC para todas as amostras de adesivo 105

Figura 68 - Gráfico do peso molecular ponderal médio 107

Figura 69 - Gráfico da espectroscopia em infravermelho (FTIR) de todas as amostras 108

Figura 70 - llustração do cálculo da área de um pico do espectro de infravermelho $\quad 110$

Figura 71 - llustração do rompimento da ligação dupla da borracha natural 112

Figura 72 - llustração da estrutura química da borracha com ligação cruzada 112 
Tabela 01 - Movimentação no mercado nacional de adesivos 9

Tabela 02 - Comparação de adesivos sensiveis à pressão 11

Tabela 03 - Processos produtivos de borrachas 32

Tabela 04 - Variação das fórmulas

Tabela 05 - Codificação dos experimentos $\quad 54$

Tabela 06 - Camada de adesivo revestida no filme de PVC 56

Tabela 07 - Camada de adesivo revestida no filme de Poliéster $\quad 57$

Tabela 08 - Resultados da viscosidade Brookfield $\quad 87$

Tabela 09 - Resultados da quantidade de materiais solidos 89

Tabela 10 - Resultados de ancoragem $\quad 91$

Tabela 11 - Resultados da resistência ao cisalhamento 93

Tabela 12 - Resultados do ensaio de grau de ligaçóes cruzadas 95

Tabela 13 - Valores de adesáo em superficie metálica 98

Tabela 14 - Valores de adesão em substrato vinílico $\quad 99$

Tabela 15 - Máxima deformação apresentada no ensaio de reometria placa paralela 104

Tabela 16 - Resultado do GPC para todas as amostras de adesivo 107

Tabela 17 - Resultado da normalização das áreas dos picos de FTIR analisados $\quad 111$

Tabela 18 - Resumo do melhor desempenho dos adesivos analisados $\quad 115$ 
ABNT - associação brasileira de normas técnicas

FTIR - espectroscopia no infravermelho com transformada de Fourier

GPC - cromatografia de permeação em gel

NB - norma brasileira registrada

$\mathrm{N} \& \mathrm{~N}$ - nanociência e a nanotecnologia

PSA - adesivo sensível à pressão (do inglês - Pressue Sensitives Adhesives)

PVC - policloreto de vinila

$\mathrm{Tg}$ - temperatura de transição vítrea

$\mathrm{ZnO}$ - óxido de zinco 
Adesivos sensiveis à pressão (PSA do inglês - Pressure Sensitive Adhesives) são produtos que aderem a superfícies imediatamente após a aplicação de pequenas pressões. Têm grandes vantagens sobre outros tipos de adesivos, principalmente por necessitarem apenas de uma aplicação inicial de pressão para apresentar o efeito permanente de adesão. Neste trabalho foram avaliadas três composições distintas de PSA, sendo uma delas considerada como referência, e duas condições diferentes de processamento, com o objetivo principal de obter um adesivo com alta resistência ao cisalhamento e boa aderência. Todas as amostras foram produzidas em laboratório utilizando um moinho de dois rolos e um misturador do tipo sigma. Essas composições foram baseadas em borrachas com insaturações, que permitem a formação de ligações cruzadas, tornando o adesivo mais resistente. As alterações impostas na composição (adição de óxido metálico e resinato) e a mudança na condição de processamento (nível de reação para formação de ligações cruzadas) levaram a diferentes propriedades dos adesivos obtidos; como valores de adesão, grau de ligação cruzada, resistência a cisalhamento e peso molecular. Os resultados encontrados neste trabalho mostram que a adição de 5 pcr de óxido de zinco aumenta em até $64 \%$ a resistência ao cisalhamento em relação à amostra de referência, enquanto que $5 \mathrm{pcr}$ de resinato de zinco causa um incremento de aproximadamente $21 \%$. Também foi possível observar que o alto nível de reação (60 minutos) confere uma quantidade de ligações cruzadas pelo menos duas vezes maior que a obtido para o baixo nível de reação (30 minutos). 
Pressure Sensitive Adhesives (PSA) are materials which bond to adherent surfaces at room temperature immediately as low pressure is applied. This kind of material has a number of advantages of adhesives bonding, especially because they need low pressure to effect permanent adhesion to an adherent. In this work three different PSA formulations were tested under two process condition. The final product obtained can be used over flexible web, as poly (vinyl chloride) tapes. Samples were prepared trough a two-roll mill and sigma mixer in a laboratory production scale. The composition was based on rubber material that has double molecular chain, which allows cross-linking, making the adhesive more resistant. Small changing on formulation (adding 5 phr of metallic oxide or zinc resinate) and process condition (reaction level) took to different results as cross-link degree, adhesion properties, shear resistance and molecular weight. The results showed that adding small amount of metallic oxide can increase up to $64 \%$ of shear resistance and adding zinc resinate compound can increase about $21 \%$. And also is possible to conclude that high reaction level (60 minutes) takes to at least double cross-linking degree compared with low reaction level (30 minutes). 
O processo de união de materiais por adesão é caracterizado pela junção de peças com o auxílio de um adesivo: uma substância capaz de segurar materiais atados através de uma superfície comum. Os adesivos têm como função principal transmitir e distribuir uniformemente a tensão de uma parte à outra, o que permite manter a união desses materiais. Há muitos compostos capazes de aderir a substratos, dentre os quais estão os adesivos sensíveis à pressão, ou mais conhecidos como PSA (do inglês - Pressure Sensitive Adhesives). Nesse universo estão os PSA baseados em borrachas sintéticas e/ou naturais. O objetivo principal deste estudo foi melhor compreender os efeitos da modificação da composição (ou formulação) e mudanças durante a fabricação (ou processamento) nas propriedades finais do adesivo a base de borracha, tendo um foco maior na alteração da resistência ao cisalhamento e a fluência sob força cisalhante.

Materiais elastoméricos, ou borrachas, são polímeros lineares que têm elevado peso molecular e apresentam escoamento entre as cadeias poliméricas. Logo, os PSA que têm como base materiais desta classe apresentam características similares, isto é, escoamento quando submetidos a um esforço. Nas diversas aplicações de produtos que utilizam esses adesivos encontram-se dificuldades geradas pela baixa resistência ao escoamento, como os três exemplos a seguir: 1) filmes plásticos laminados em um dorso de papel com esses adesivos (exemplo: conhecidos como colantes ou adesivos decorativos) podem apresentar uma movimentação entre as camadas (plástico/papel) devido a essa deficiência, 2) fita adesiva aplicada em 
mascaramento de pára-choques na indústria automobilistica pode apresentar um escorregamento quando submetidas a altas temperaturas durante um longo período (situação comum em processos de secagem após pintura) e, por último, 3) fitas plásticas podem sofrer deformações devido ao alívio das tensões de enrolamento (aplicadas durante a fabricação dos rolos), permitido pelo adesivo pouco resistente ao cisalhamento. É fácil perceber que todos esses defeitos geram insatisfação e prejuizos financeiros para o cliente, seja ele um usuário final ou uma indústria manufatureira. No caso do laminado de filme plástico com dorso de papel, a peça pode ser inutilizada caso a movimentação seja significativa. Para o exemplo da indústria automobilística, o escorregamento da fita de mascaramento pode comprometer o acabamento do pára-choque, o que vai gerar ou um refugo ou um "re-trabalho". Este geralmente representa um alto custo para a indústria, principalmente as que têm instalações do tipo produção em série. Já a deformação do rolo de fita pode comprometer o seu uso e gerar uma insatisfação do cliente.

Para evitar ou minimizar os problemas de escoamento, da mesma maneira que nos elastômeros, ligações cruzadas são desenvolvidas nos PSA's baseados em borrachas. Artefatos de borracha vulcanizados, isto é, com a presença de uma grande quantidade de ligação cruzada, podem ser estirados, geralmente, em torno de $600 \%$ do seu tamanho original e retornarem a sua posição inicial sem deformação residual. Isso ocorre graças à presença das ligações cruzadas entre as cadeias poliméricas adjacentes. O mesmo mecanismo pode ser empregado nos adesivos sensíveis à pressão a base de borracha, porém o grau de ligações cruzadas deve ser controlado, pois um 
excesso pode causar a perda completa do poder de adesão, tornando o produto um artefato de borracha ao invés de um composto aderente.

Neste estudo foram obtidas amostras em escala laboratorial a partir de três formulações distintas, sendo que duas das fórmulas partiram de uma utilizada industrialmente (fórmula um). Também foram analisadas duas condições de processamento pré-estabelecidas que causaram mudanças na formação de ligações cruzadas. A principal meta foi verificar o impacto dessas alterações (composição e variável de processamento) sobre as propriedades de resistência ao cisalhamento e fluência sob cisalhamento e verificar se outras propriedades também importantes, como poder de adesão e poder de ancoragem ao substrato, foram afetadas. No capitulo 2 é apresentada a revisão bibliográfica das principais teorias de adesão, tipos de esforços suportados pelos adesivos e os principais materiais e métodos de processamentos utilizados para fabricação dos adesivos sensíveis à pressão. No capítulo 3 encontram-se os procedimentos utilizados para realização dos ensaios das propriedades reológicas, propriedades de adesão, de ancoragem ao substrato, de resistência a fluência e ao cisalhamento e propriedades físicoquímicas. No capítulo 4 é apresentado o conjunto de resultados dos ensaios e uma discussão. Finalmente, no capitulo 5 é apresentada uma conclusão do trabalho a partir de um resumo das propriedades exibidas para as seis amostras obtidas (três fórmulas e duas condições de processamento para cada uma) e uma das amostras foi eleita como o adesivo sensível à pressão a base de borracha que apresentou o melhor conjunto de propriedades, dentre as variações empregadas neste trabalho. 


\subsection{História dos adesivos}

Adesivo é o nome dado às substâncias capazes de unir materiais através de uma superfície de contato. Essa é uma definição genérica, que também pode ser expandida para outros termos como cola, goma e cimento. O uso desses materiais para unir superfícies é uma das técnicas mais antigas utilizadas pela humanidade. Porém, a tecnologia envolvida nos processos de fabricação e aplicação desses materiais não sofreu grandes avanços até o início do século XX. Documentos ${ }^{(1)}$ mostram que adesivos são usados há mais de três mil anos. Cimento derivado de betume (mistura líquida ou sólida de hidrocarbonetos naturais) foi usado como argamassa na construção da Torre de Babel, colas derivadas da seiva de árvores foram usadas pelos egípcios. Um exemplo bíblico do conhecimento remoto dos adesivos está no capítulo vinte e dois dos Eclesiásticos, onde indica que para se fazer uma seleção apropriada do adesivo deve-se levar em consideração a compatibilidade do mesmo com o substrato a ser aderido. Até hoje engenheiros vêm lutando para resolver problemas similares aos encontrados nos documentos da igreja. Durante a segunda guerra mundial, a ciência da adesão sofreu grandes avanços, principalmente relacionados com aderência a metal devido a requisitos militares. Nesta época foram desenvolvidos adesivos com resinas fenólicas e borrachas sintéticas para aplicação em substratos metálicos, o que confere boa resistência mecânica e ao destacamento. A partir dos anos 50 a 
indústria do adesivo sofreu grandes progressos e continuam sendo criadas novas tecnologias para aderência. Formulações diferenciadas são criadas a cada dia com a demanda crescente, principalmente devido à inexistência de um produto adesivo universal e à necessidade da humanidade de gerar bens materiais de consumo.

\subsection{Materiais utilizados nos adesivos}

Adesivos são comumente formulados a partir de uma mistura de diferentes materiais. A composição desses e suas proporções dependem da propriedade final desejada. A primeira cola industrial foi comercializada em $1700^{(22)}$ e era produzida a partir de pele animal. Por volta de 1750 , produtos adesivos obtidos a partir dos mais diversos materiais, como gordura de peixes, ossos de animais, amido natural, borrachas naturais e proteinas do leite, foram patenteados ${ }^{(22)}$. Logo no início do século $X X$ colas baseadas em polímeros sintéticos começaram a ser desenvolvidas e disponibilizadas para o mercado, apresentando boa aceitação, principalmente por conferirem resistência química, flexibilidade, propriedades mecânicas diferenciadas e baixo tempo de cura. A partir daí a indústria de adesivos sofreu um grande avanço, começou a criar formulações baseadas em materiais sintéticos e muitas vezes misturas com materiais naturais. Por exemplo, cargas minerais como óxidos metálicos e breus são misturados com polímeros, gerando produtos com propriedades muito distintas.

Por muitos anos as formulações de adesivos mais utilizadas continham resinas sintéticas, que poderiam ser termoplásticas, termofixas ou 
elastoméricas, ou ainda uma mistura desses materiais, cargas minerais para reforçar, pigmentar, alterar o coeficiente de expansão, reduzir o encolhimento do produto, controlar propriedades reológicas (tixotropia e reopexia), entre outras vantagens, catalisadores principalmente para adesivos baseados em materiais termofixos, óleos minerais ou sintéticos, emulsões acrílicas, materiais para expansão (espumas) entre outros. Entretanto, mesmo com toda essa gama de matérias-primas para a criação de novos adesivos, foi necessário o avanço das tecnologias empregadas para a fabricação e processamento desses materiais para produzir adesivos específicos para algumas aplicações exigidas pelo mercado.

Recentemente, a nanociência e a nanotecnologia ( $N \& N)$, que têm por meta dominar parte do virtuosismo da natureza na organização da matéria átomo por átomo, molécula por molécula, têm servido de inspiração para desenvolvimento de novos adesivos. Na área de materiais, o potencial da $\mathrm{N} \&$ $\mathrm{N}$ é imenso, novas cerâmicas, polímeros e borrachas estão sendo criados com propriedades superiores aos já existentes. Há pouco tempo os nanomateriais começaram a serem empregados nas formulações dos adesivos ${ }^{(23,20)}$ e vêm apresentando resultados satisfatórios. Acredita-se que em futuro próximo esses materiais vão substituir grande parte dos materiais convencionais devido às suas propriedades superiores.

\subsection{Vantagens e desvantagens dos adesivos}

Abaixo estão algumas vantagens e desvantagens apresentadas pelos mais diversos adesivos comercializados atualmente. É importante lembrar que 
existem produtos específicos para algumas aplicações técnicas, que não se enquadram nesta lista.

\section{VANTAGENS:}

- Promove uma distribuição uniforme da tensão;

- Une materiais de várias espessuras - espessos ou delgados;

- Minimiza ou previne corrosão eletrolítica entre materiais distintos;

- Resiste a fatiga e carregamentos cíclicos;

- Sela as superfícies contra ataques de uma enorme variedade de meios agressivos;

- Isola contra transferência de calor e condução elétrica;

- Absorve choque e vibrações

\section{DESVANTAGENS:}

- A região de união não permite visualização (exceto para adesivos transparentes);

- Requer uma preparação da superfície;

- Pode ser necessário um longo tempo de cura, além de estufas e autoclaves;

- Necessidade de pressão parcial até que a adesão fornecida pelo produto suporte a carga exigida;

- Baixas temperaturas de serviço (geralmente até $180^{\circ} \mathrm{C}$ ); 
- Adesivos de origem vegetal ou animal podem ser atacados por bactérias;

- Exposição a solventes pode afetar a saúde do usuário do produto.

\subsection{Uso de adesivos no mundo}

O mercado mundial de adesivos vem apresentando alto crescimento há algumas décadas. Em 2000 esses produtos movimentaram aproximadamente US\$ 30 bilhões em todo o mundo ${ }^{(2)}$. Na Figura 01 se observa a distribuição deste volume nos principais mercados mundiais (fonte: ChemQuest Group):

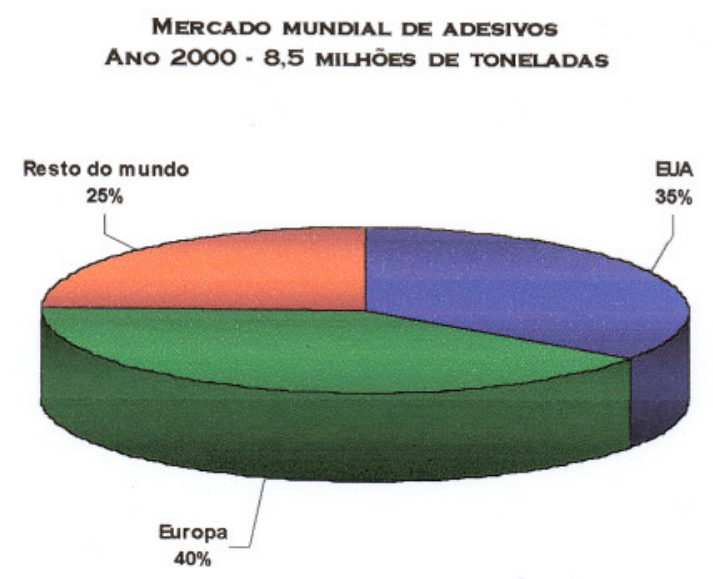

Figura 01 - Distribuição do mercado mundial de adesivos ${ }^{(2)}$

Da mesma maneira que o cenário mundial, o Brasil vem apresentando forte crescimento no mercado de adesivos. O consumo per capita sulamericano de adesivos utilizados em laminados de papel, alumínio e plástico, é de aproximadamente $3,0 \mathrm{~kg}$ anuais. Apesar de ser um número expressivo, 
ainda é cerca de três vezes menor que o norte-americano. Na Tabela 01 é apresentada a evolução do mercado nacional de adesivos:

Tabela 01 - Movimentação no mercado nacional de adesivos

HISTÓRICO DAS IMPORTAÇÕES E DAS EXPORTAÇÕES DE ADESIVOS NO BRASIL (EM TONELADAS)

\begin{tabular}{|c|c|c|c|c|c|c|c|c|c|}
\hline ANO & 1992 & 1993 & 1994 & 1995 & 1996 & 1997 & 1998 & 1999 & 2000 \\
\hline IMPORTAĊ̃̃O & 1.510 & 2.366 & 2.974 & 6.884 & 8.645 & 12.668 & 17.319 & 23.425 & 27.947 \\
\hline EXPORTAĊ̃̃O & 3.128 & 7.610 & 6.435 & 6.619 & 8.116 & 9.338 & 9.136 & 10.494 & 14.318 \\
\hline
\end{tabular}

* fonte: Abiquim

\subsection{Classificação dos adesivos}

Há um grande número de classificações de adesivos, cada qual com uma vantagem específica:

- Função: diferencia adesivos de estruturais (de alta performance) e não estruturais (produtos que não suportam altas cargas);

- Composição química: classifica como produtos termoplásticos, termofixos ou elastoméricos;

- Forma física: diferencia adesivo líquido, em pasta, granulados, em pó, na forma de filme, entre outros;

- Aplicação: divide em grupos de produtos que podem ser utilizados em spray, aplicados com pincel, bombeados, extrudados, calandrados, etc;

- Outras classes.

Entretanto, não existe uma classificação reconhecida universalmente.

A SME (em inglês - Society of Manufacturing Engineers) ${ }^{(15)}$ publicou uma classificação que diferencia em detalhes os mais diversos adesivos existentes, como segue: 
1) Adesivos que reagem quimicamente

1.1) Catálise através de vários componentes;

1.2) Catálise através de um único componente;

2) Adesivos que necessitam de evaporação do veículo líquido

1.1) Sistemas base solvente;

1.2) Sistemas base d'água;

3) Adesivos que fundem com aplicação de calor (do inglês - Hot-melt)

4) Adesivos com aderência retardada (do inglês - Delayed-Tack)

5) Adesivo na forma de filme

6) Adesivo sensivel à pressão (do inglês - Pressure sensitive adhesive)

\subsection{Introdução a adesivos sensiveis à pressão}

Os adesivos sensiveis à pressão (PSA - pressure sensitive adhesive) aderem a superfícies a temperatura ambiente imediatamente após a aplicação de pequenas pressões. São utilizados em várias aplicações, como: fitas, etiquetas e laminados. Geralmente o PSA compõe produtos de dois componentes: o adesivo e o dorso. O substrato (também conhecido como dorso) pode ser composto por diversos materiais, incluindo:

- Filmes termoplásticos (polietileno, poliéster, polipropileno, poli(cloreto de vinila) - PVC, etc);

- Papel e

- Metal (filme de alumínio). 
Os PSA's podem ser classificados em três grupos, de acordo com sua base de polímeros: elastomérico (derivado de borracha natural ou sintética), acrílico e silicone. A tabela 02 exibe uma comparação das principais propriedades exigidas desses materiais.

Tabela 02 - Comparação de adesivos sensiveis à pressão

\begin{tabular}{lccc}
\hline \hline \multicolumn{1}{c}{ Propriedade } & Elastomérico & Acrilico & Silicone \\
Custo & baixo & médio & alto \\
Aderência & moderada-alta & baixa-alta & baixa-moderada \\
Resistência ao cisalhamento & baixa-alta & baixa-alta & moderada \\
Resistência à umidade & excelente & excelente & excelente \\
Temperatura de trabalho & -10 a $120^{\circ} \mathrm{C}$ & -40 a $150^{\circ} \mathrm{C}$ & -70 a $250^{\circ} \mathrm{C}$ \\
Aplicação & interior & interior e exterior & interior e exterior \\
Resistência a UV & baixa-alta & excelente & excelente \\
Coloração & amarela & transparente & transparente \\
Resistência química & baixa & boa & excelente \\
Resistência a plastificantes & baixa & baixa & boa \\
Aderência a substratos de alta energia & excelente & excelente & excelente \\
Aderência a substratos de baixa energia & moderada & baixa-alta & alta \\
\hline \hline
\end{tabular}

Os adesivos sensíveis à pressão a base de borracha (elastoméricos) aderem a uma maior quantidade de substratos quando comparados com os acrílicos. Entretanto, apresentam uma baixa resistência a UV e uma menor faixa de temperatura de trabalho. Os adesivos acrílicos preenchem a lacuna formada entre o elastomérico e o de silicone em termos de custo e performance. Formulações baseadas em silicone exibem altas temperaturas de trabalho e resistência química, entretanto são caras e exibem baixa aderência.

Para se obter um adesivo sensível à pressão que atenda todas as necessidades da aplicação deve-se levar em contar, além da base polimérica, a formulação, o método de processamento, o substrato, a superfície onde será aplicado, o esforço exigido e as condições do ambiente. 


\subsection{História dos adesivos sensíveis à pressão}

Foi durante a metade do século XIX que surgiu a indústria de adesivos sensíveis à pressão (PSA). Neste período, foram desenvolvidos as fitas adesivas e os emplastros utilizados em aplicações médicas, o que demandava um alto consumo deste tipo de produto. Foi também neste período que apareceram as primeiras patentes relacionadas com adesivos sensiveis à pressão. Em $1845^{(21)}$, nos Estados Unidos da América, Shecut and Day patentearam um trabalho relacionado com PSA. Em 1882, o farmacêutico europeu Beiersdorf estudou emplastros e PSA obtidos a partir de guta-percha.

A produção em larga escala de fitas cirúrgicas cobertas com adesivos sensíveis à pressão começou em 1874 quando Johnson e Seaburg inauguraram uma fábrica em New Jersey, E.U.A. Em 1886 Johnson fundou a Johnson \& Johnson Company, a maior empresa, até os dias de hoje, fabricante de fitas para aplicação na medicina.

Por um longo período a aplicação desse tipo de adesivo se limitou à industria médica. Somente no início de 1920 foi desenvolvido um outro uso para o PSA. As primeiras fitas isolantes para aplicações elétricas surgiram no período de 1920 a $1930{ }^{(16)}$. Neste mesmo período Richard G. Drew (funcionário da $3 \mathrm{M}$ - Minnesota Mining and Manufacturing Company) desenvolveu uma fita de papel com PSA, utilizada para "mascaramento" na

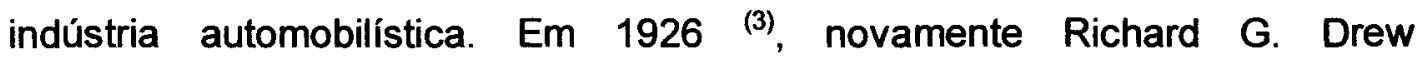
desenvolveu uma fita de celofane com adesivo sensivel à pressão para fechamento de caixas de papelão. 
Em meados de 1930 a companhia Stanton Avery, Califórnia, U.S.A., começou a imprimir etiquetas autocolantes, cobertas com PSA. Durante a segunda Guerra Mundial houve uma expansão da demanda dessas etiquetas, fazendo com que a Avery se tornasse mundialmente conhecida, principalmente na Europa.

\subsection{Teoria da adesão}

Até hoje os mecanismos de adesão não são compreendidos por completo. Muitas teorias foram propostas, porém, um único modelo não explica todas as propriedades dos materiais adesivos. O processo de aderência a um objeto ou a uma superfície é uma somatória de forças mecânicas, químicas e físicas. Existem algumas teorias ${ }^{(4,20)}$ que explicam, de uma maneira particular, esses fenômenos: o intertravamento mecânico causado pela ancoragem mecânica do adesivo nos poros da superfície a ser aderida, forças eletrostáticas geradas pela diferença de eletronegatividade das duas partes (adesivo e substrato), teoria da adsorção causada pelas forças intermoleculares superficiais, adsorção química em decorrência das interações moleculares e a difusão que é evidenciada em adesivos de cadeias poliméricas longas. A seguir é apresentado com mais detalhe cada um desses mecanismos. 
1) Intertravamento mecânico (do inglês - Mechanical interlocking):

De acordo com esta teoria, para que um adesivo funcione propriamente o mesmo deve penetrar nos poros, buracos, cavidades e outras irregularidades da superfície do substrato, travando mecanicamente após expulsar o ar que ali estava. Além de apresentar uma boa molhabilidade à superfície, o adesivo deve exibir características físico-químicas que permitam que o mesmo penetre nas aberturas superficiais em um curto espaço de tempo. Esse mecanismo explica alguns exemplos comuns, como a de adesivos a base de borracha em substratos têxteis e de papel. A Figura 02 ilustra 0 mecanismo de intertravamento mecânico.

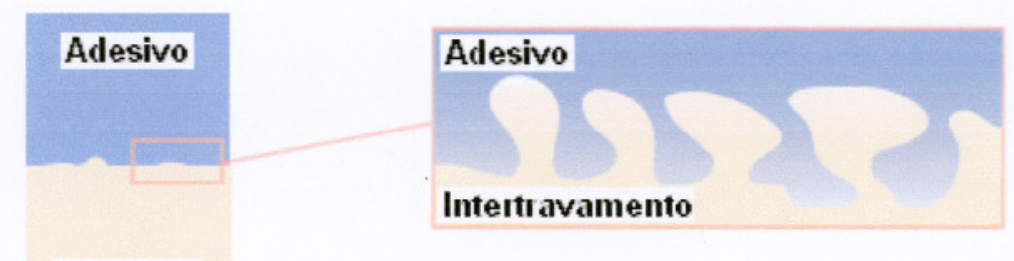

Substrato

Figura 02 - Ilustração do mecanismo de intertravamento mecânico

Para que o fenômeno de adesão por intertravamento mecânico seja realçado, tratamentos superficiais são feitos previamente. Esses causam microrugosidade superficial, o que faz com que o poder de penetração do adesivo aumente, além de causar um acréscimo da área superficial, conseqüentemente, um aumento da molhabilidade. 
2) Eletrostática:

O conceito básico da teoria eletrostática da adesão está na diferença de eletronegatividade dos materiais envolvidos no mecanismo. A força adesiva é atribuída à transferência de elétrons através da interface, criando cargas positivas $\left(\delta^{+}\right)$e negativas $\left(\delta^{-}\right)$. Por exemplo, quando um polímero orgânico entra em contato com um metal, elétrons são transferidos do metal para o polímero, criando uma dupla camada de cargas. A Figura 03 ilustra o fenômeno de eletrostática em adesivos.

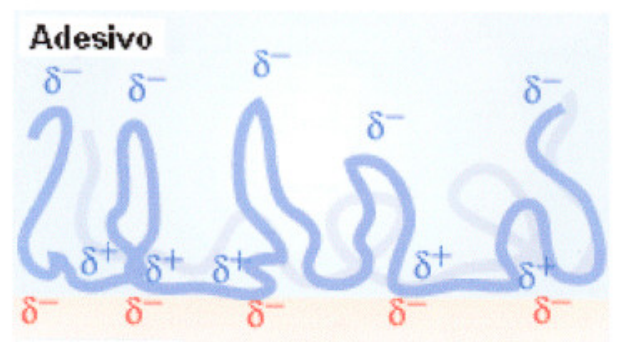

Substrato

Figura 03 - Ilustração da teoria de interação eletrostática

Essa força eletrostática gerada entre as cargas positivas e negativas é capaz de evitar a separação das partes ligantes (substrato e adesivo). Durante muitos anos a veracidade deste mecanismo foi questionada, pois não havia sido comprovada a presença da dupla camada na interface de um conjunto superfície e adesivo. Porém, após ser evidenciada a presença de descarga elétrica ${ }^{(4)}$ durante o destacamento do adesivo da superfície aderida, ficou comprovada a capacidade de aderência devido à eletrostática. 
3) Teoria da adsorção (do inglês - Adsorption Theory):

Essa teoria explica o fenômeno de adesão resultante do contato intermolecular entre dois materiais e interpreta as forças desenvolvidas entre os átomos das duas superfícies (adesivo e substrato). É considerado o princípio mais importante do fenômeno adesão. As forças superficiais mais comuns formadas entre as superfícies envolvidas no mecanismo são as de Van der Waals. Além disso, interações ácido-base e ligações de hidrogênio também contribuem para a ocorrência da adesão. Pesquisas (20) demonstraram experimentalmente que muitos mecanismos de adesão envolvem apenas forças interfaciais secundárias. O cálculo teórico dessas forças atrativas resulta em valores maiores dos que encontrados experimentalmente, porém, essa discrepância é explicada pela presença de vazios, defeitos ou outras irregularidades geométricas, o que causa concentração de tensão durante a aplicação do esforço (carregamento de uma carga) na interface. A Figura 04 ilustra esse mecanismo.

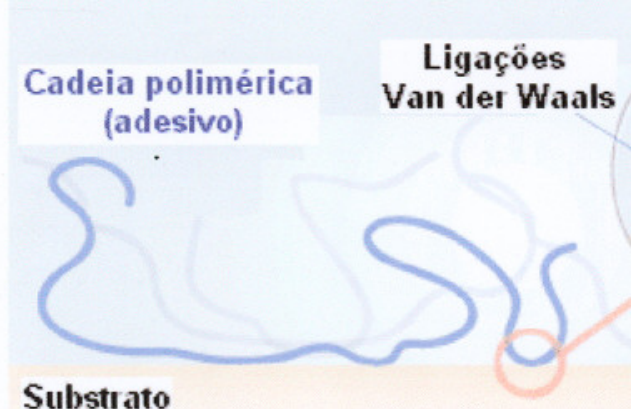

Figura 04 - Ilustração do mecanismo de adsorção 
Para se obter uma boa adsorção, um contato íntimo é fundamental para que seja possível a formação de ligações de Van der Waals ou interação ácidobase, ou ainda as duas concomitantes. Para tal, é essencial que o adesivo apresente uma boa molhabilidade. De acordo com a equação de Young, a tensão superficial entre os três estados físicos da matéria (líquido/ gás: $\gamma_{\text {LG, }}$ sólido/ líquido: $\gamma_{\mathrm{SL}}$ e sólido/ gás: $\gamma_{\mathrm{SG}}$ ) está relacionada com um ângulo de contato de equilíbrio $(\sigma)$ através da seguinte equação:

$$
\gamma_{S G}=\gamma_{S L}+\gamma_{L G} \cdot \cos \sigma
$$

Um fator importante que influencia a força envolvida na adesão é a habilidade do material de espalhar espontaneamente na superfície do substrato. Para que essa molhabilidade espontânea ocorra é preciso que:

$$
\gamma_{S G} \geq \gamma_{S L}+\gamma_{L G} \cdot \cos \sigma
$$

A figura 05 representa as tensões superficiais envolvidas na teoria.

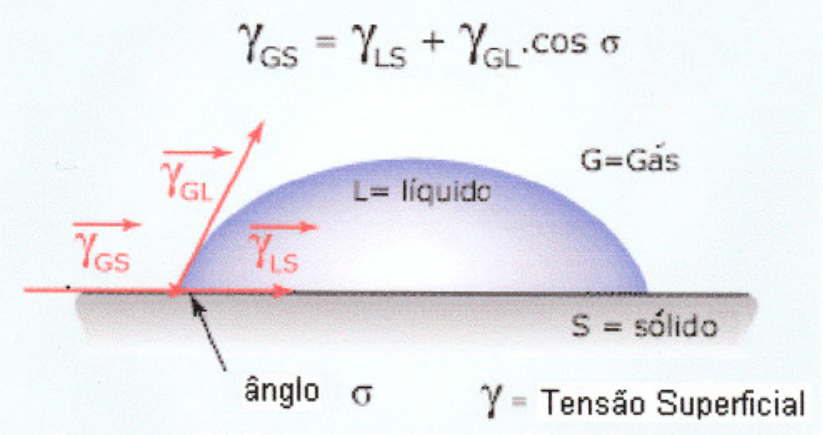

Figura 05 - Ilustração do ângulo de contato

Para o adesivo apresentar uma boa molhabilidade, a tensão superficial do líquido (adesivo) deve ser menor do que a tensão crítica de molhabilidade 
da superfície do substrato. As Figuras 06 e 07 ilustram comportamentos de molhabilidade de líquidos em substratos sólidos:

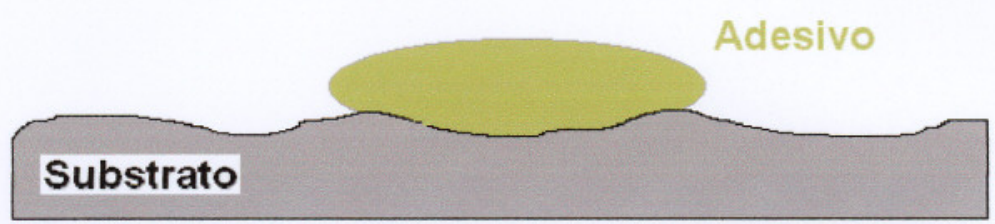

Figura 06 - Ilustração de boa "molhabilidade" apresentada por um adesivo

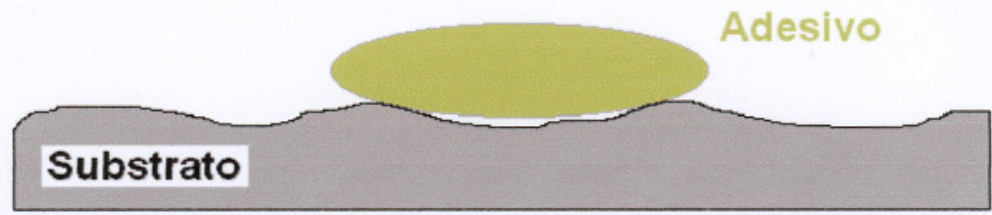

Figura 07 - Ilustração de "Molhabilidade" fraca apresentada por um adesivo

Adesivos obtidos através da nanociência e nanotecnologia ( $N \& N)$, com alta organização entre moléculas que compõem os materiais utilizados, favorecem o contato intermolecular entre os dois materiais (adesivo e substrato), isto é, aumenta a molhabilidade e, conseqüentemente, aumenta a força desenvolvida entre as moléculas das duas superfícies.

4) Teoria da adsorção química (do inglês - Chemisorption Theory):

Esse mecanismo sugere que ligações químicas primárias ocorrem perpendicularmente à interface formada entre o adesivo e o substrato, conferindo o efeito de adesão. Ligações químicas primárias são extremamente fortes e muitas vezes contribuem significantemente para adesão intrínseca. A Figura 08 ilustra a teoria da adsorção química. 


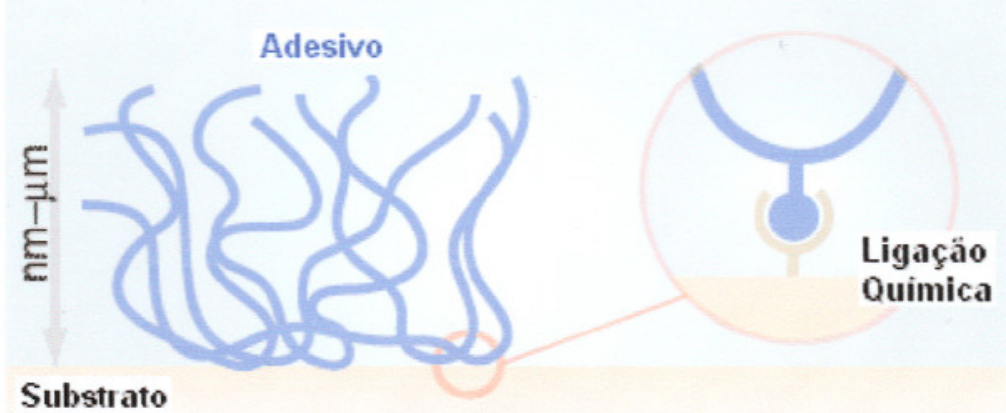

Figura 08 - llustração da teoria da adsorção química

Ligações químicas primárias exibem energias que variam de 60 a 1100 $\mathrm{kJ} / \mathrm{mol}$, o que é considerada alto quando comparada com a energia apresentada pelas ligações químicas secundárias (de 0.08 a $5 \mathrm{KJ} / \mathrm{mol}$ ). Devese citar que, em muitas aplicações, agentes promotores de adesão podem ser adicionados à superfície do substrato para que o mecanismo de adsorção química (que envolve ligações químicas primárias) seja favorecido, conferindo melhores resultados de aderência. Este mecanismo explica um número limitado de casos porque as ligações covalentes só ocorrem quando os materiais do substrato e do adesivo reagem quimicamente. Todavia, nos casos em que acontece adsorção química, este é o mecanismo predominante.

5) Teoria da difusão:

Essa teoria atribui o efeito de adesão de materiais poliméricos à interpenetração de cadeias químicas cruzando a interface dos materiais. Esse conceito só é válido quando, tanto o adesivo quanto o substrato forem polímeros, os quais devem ser capazes de apresentar movimentação das 
cadeias (isto é, a temperatura de aplicação deve ser acima da temperatura de transição vítrea - $T_{g}$ ), serem compatíveis e miscíveis. A Figura 09 ilustra esse mecanismo.

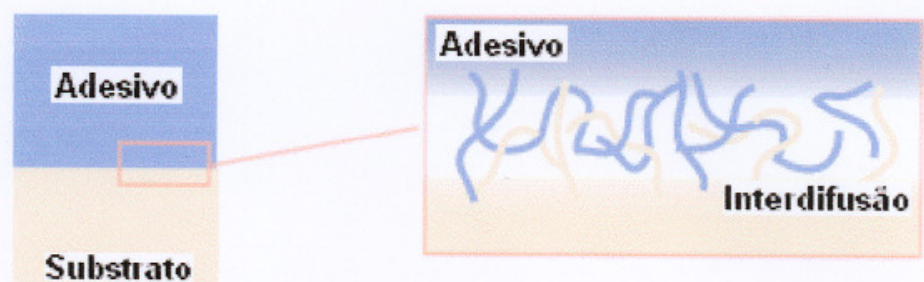

Figura 09 - Ilustração da teoria da difusão

Existem alguns parâmetros que afetam o processo de difusão, entre eles estão: o tempo para contato entre o adesivo e o substrato, temperatura de aplicação, peso molecular dos polímeros envolvidos no evento e fórmula física dos materiais (líquido ou sólido). A polaridade também beneficia o efeito de adesão.

Algumas evidências ${ }^{(20)}$ comprovaram o fenômeno de interdifusão em polímeros com mobilidade e compatíveis, além de promoverem adesão intrínseca. Também foi notado ${ }^{(20)}$ que esta teoria não é válida para aplicações em que os polímeros e o substrato não eram solúveis entre si ou não exibiam movimentação molecular ou ainda estavam abaixo de sua temperatura de transição vítrea $\left(\mathrm{T}_{\mathrm{g}}\right)$. 


\subsection{Tipos de esforços suportados pelos adesivos}

Adesivos são submetidos a, basicamente, cinco tipos de esforços nas mais diversas aplicações. Também é comum se observar uma combinação desses eventos. Esses tipos são:

1) Compressão: ocorre quando um tipo da carga puramente compressivo é aplicado perpendicularmente à área de contato.

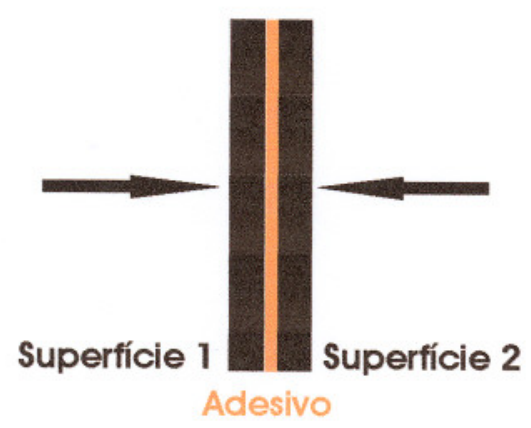

Figura 10 - llustração de um esforço compressivo

2) Cisalhamento: este tipo de carregamento ocorre quando tensões contrárias são aplicadas à área aderida.

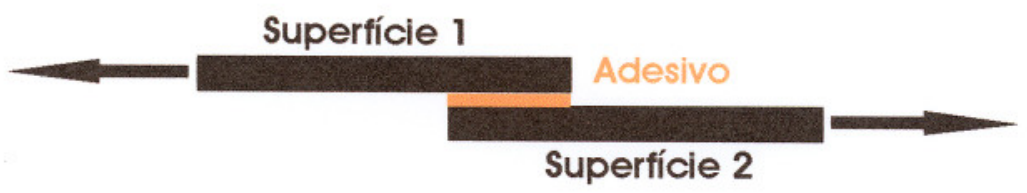

Figura 11 - Ilustração de um esforço cisalhante 
3) Tração: ocorre quando uma tensão é aplicada perpendicularmente à área de contato.

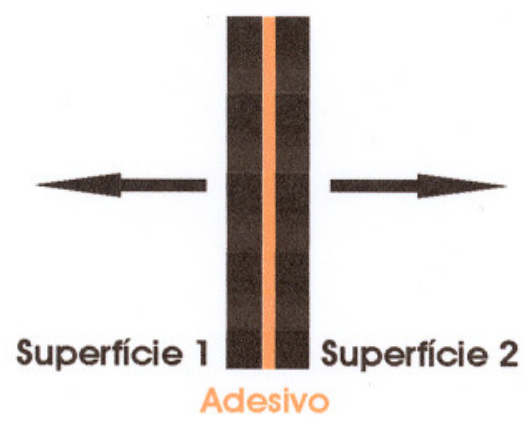

Figura 12 - Ilustração de um esforço sob tensão

4) Destacamento: esse tipo de esforço se dá quando uma ou ambas as superfícies aderentes são flexíveis. Uma tensão é aplicada na linha de aderência e um dos substratos é submetido ao destacamento.

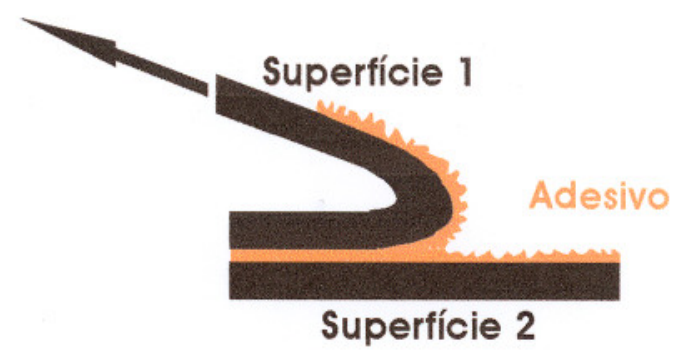

Figura 13 - Ilustração de um esforço sob destacamento

5) Fissura: é um evento muito parecido com o destacamento, porém ocorre para substratos rígidos. 


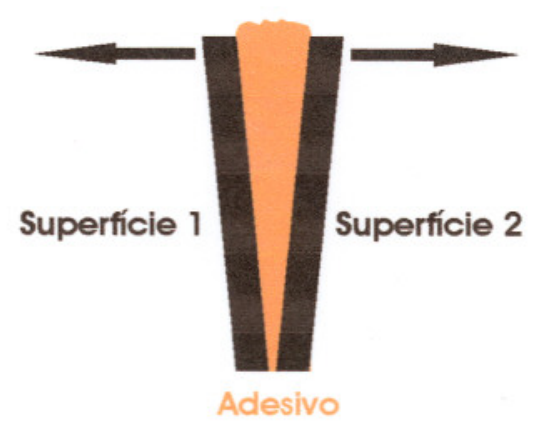

Figura 14 - Ilustração de um esforço do tipo fissura

Neste trabalho serão estudados apenas os esforços do tipo cisalhamento (shear) e destacamento (peel), pois são as situações de esforços mais comuns para adesivos sensíveis à pressão aplicados em fitas, etiquetas e laminados flexíveis.

\subsection{Materiais mais utilizados na composição de PSA}

\subsubsection{Borrachas}

Borrachas ou elastômeros são polímeros (lineares e de alta massa molecular) que apresentam moléculas de cadeias longas, as quais têm boa flexibilidade, permitindo que o material sofra longa deformação quando submetido à tensão ${ }^{(6)}$. São amorfos à temperatura ambiente e apresentam temperatura de transição vítrea $\left(\mathrm{T}_{\mathrm{g}}\right)$ abaixo da temperatura ambiente.

Para uma borracha chamada "crua" ou "verde", isto é, um elastômero que não possui ligações cruzadas, a aplicação de tensão causa um escorregamento entre as cadeias poliméricas, fazendo com que o material apresente deformação (da mesma maneira que os termoplásticos). Com a 
introdução de ligações cruzadas entre as cadeias poliméricas, processo conhecido como vulcanização ou processo de cura, o escorregamento entre as cadeias é evitado, garantindo uma maior elasticidade ao produto sem deformação residual.

As borrachas são divididas em dois principais grupos: borracha natural e borracha sintética.

\subsubsection{Borracha Natural}

A borracha natural é obtida a partir de um látex, o qual pode ser extraído de uma infinidade de espécies de árvores. Porém, a espécie Hevea Brasiliensis atualmente é adotada como a planta mais comum para a obtenção do látex, pois é capaz de produzi-lo com propriedades que atendam às necessidades das indústrias. A árvore da classe Hevea Brasiliensis originou-se na floresta Amazônica e só pode ser cultivada em regiões que têm um clima similar, isto é, altas temperaturas e alta umidade. Isto restringe a produção deste látex em regiōes situadas a $20^{\circ}$ de latitude norte e sul da linha do Equador. Esse tipo de planta tem aproximadamente 20 metros de altura e uma raiz muito profunda. $A$ primeira colheita do látex proveniente desta árvore só pode ser feita em árvores com pelo menos seis anos de idade.

A produção da borracha natural começa com a abertura de sulcos no caule da árvore para que o látex flua por esses canais até o ponto de coleta, que geralmente é localizado na parte inferior da árvore. O látex é então submetido ao processo de coagulação através da sua diluição em água, aproximadamente de $12 \%$ a $18 \%$ de concentração de material sólido, e adição 
de agente coagulante, geralmente ácido fórmico ou ácido acético. Quando o pH da solução estiver entre 5,1 e 4,8 ocorre a coagulação desse material. Após esta etapa, esse produto pode ser transformado em borracha natural do tipo "folha defumada" (smokedsheet), processo que submete o látex coagulado à presença de fumaça durante um periodo de dois a três dias. Ou pode ser transformado em borracha do tipo crepe, que apresenta um índice de pureza muito maior que a do tipo "folha defumada". Neste tipo de processamento, após várias etapas de lavagem o látex é submetido a um processo de secagem ao ar por um período que pode variar de 10 a 12 dias.

A fórmula química (monômero) da borracha natural é o cis-1,4-poliisopreno, mostrada na Figura 15.

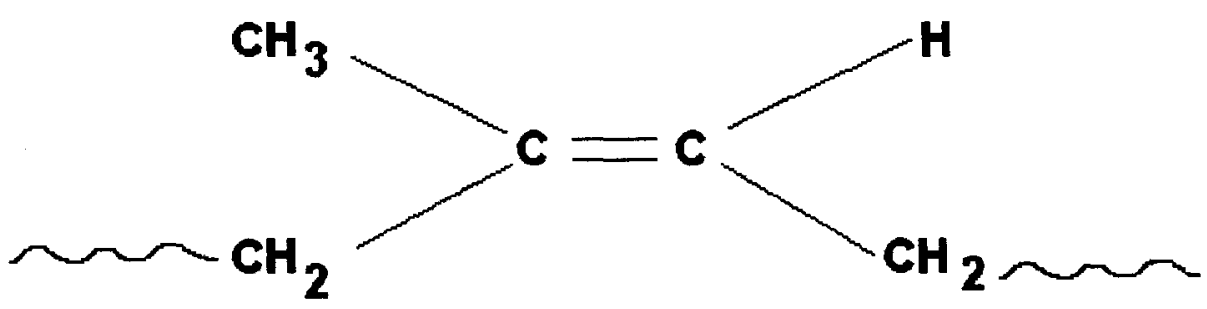

Figura 15 - Fórmula química da borracha natural (cis-1,4-poliisopreno)

Atualmente é possível encontrar no mercado uma grande variedade (grades) de borracha natural, as quais apresentam propriedades muito distintas. Alguns exemplos são: borracha em pó ou particulada, a OE-NR (Oil Extended Natural Rubber) borracha natural com óleo extensor, ENR (Epoxidized Natural Rubber) borracha natural com grau de epoxidação, etc. Também há uma classificação muito comum no mercado internacional, um exemplo é a borracha natural SMR (Standardized Malaysian Rubber), borracha padrão da Malásia, que pode ser encontrada em vários tipos. 
Nas Figuras 16, 17, 18 e 19 estão alguns dados estatísticos ${ }^{(7)}$ que mostram a distribuição mundial das regiões que mais produzem e consomem borracha natural.

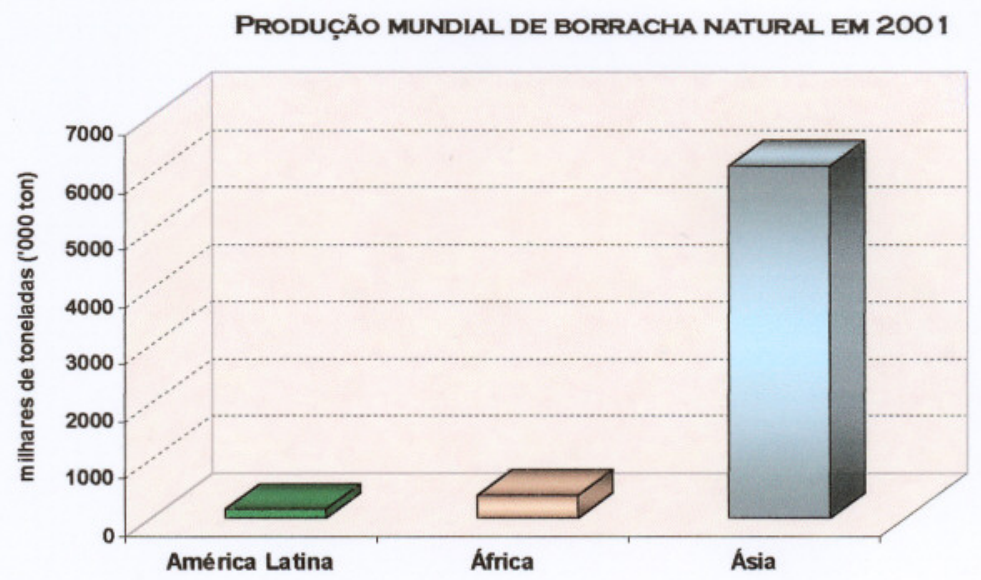

Figura 16 - Distribuição da produção mundial de borracha natural ${ }^{(7)}$
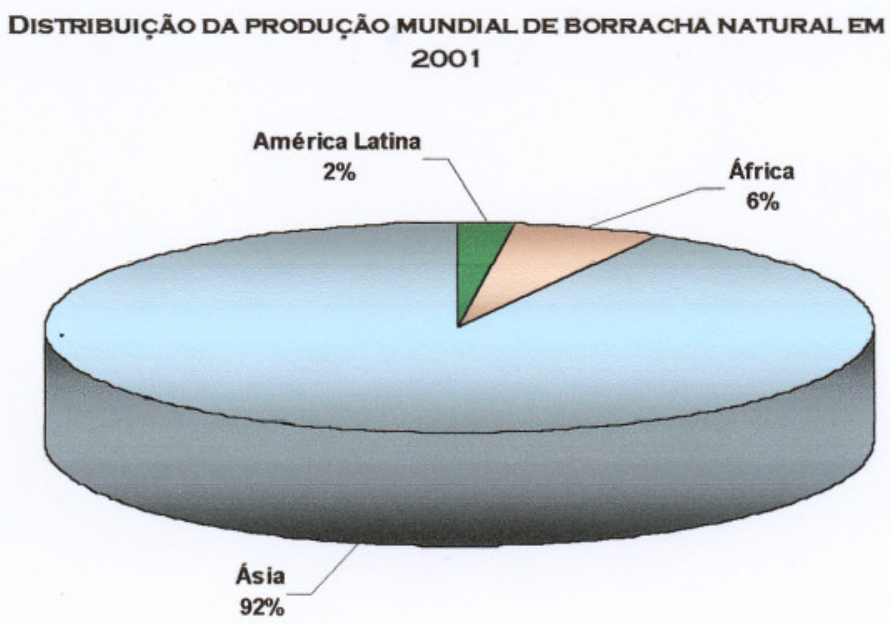

Figura 17 - Distribuição da produção mundial de borracha natural ${ }^{(7)}$ 


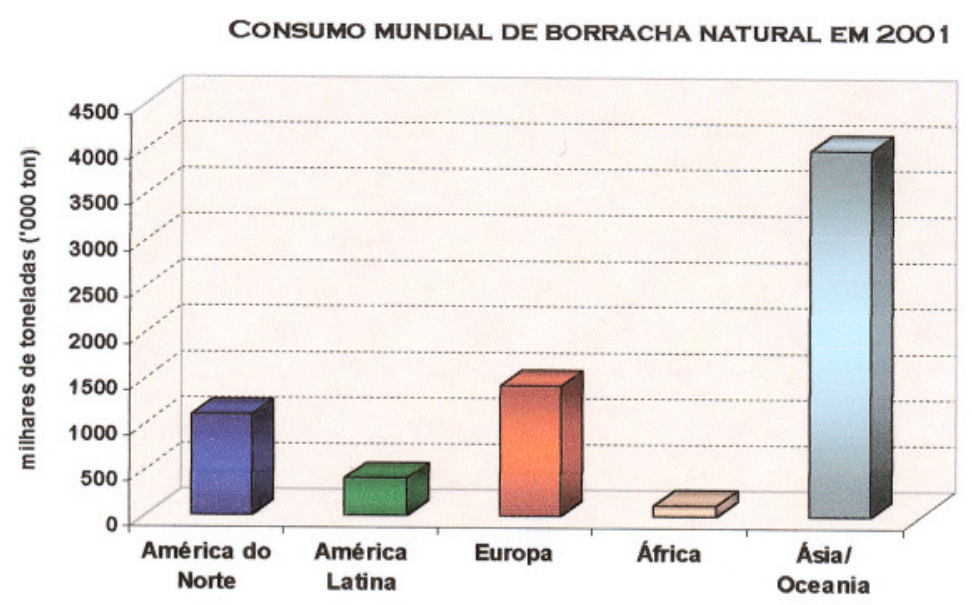

Figura 18 - Distribuição do consumo mundial de borracha natural ${ }^{(7)}$

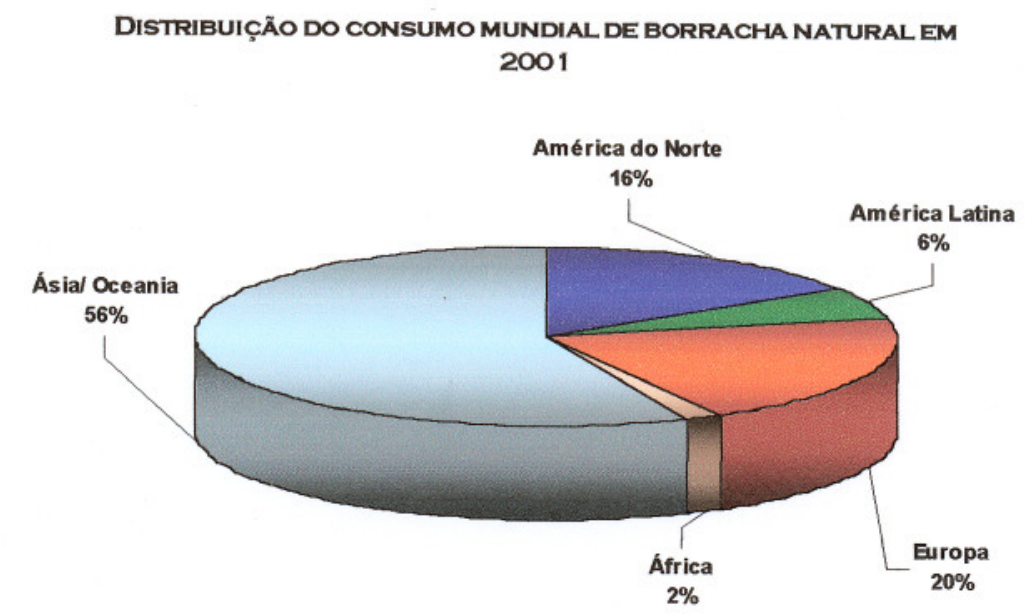

Figura 19- Distribuição do consumo mundial de borracha natural ${ }^{(7)}$

Entre os países asiáticos, a Malásia se destaca por ser considerada a maior produtora de borracha natural do mundo. Em 1985 ela detinha uma participação de $34,9 \%$ da produção mundial ${ }^{(7)}$. 


\subsubsection{Borracha Sintética}

O termo borracha sintética se refere a uma grande variedade de elastômeros obtidos através de uma síntese química. Esse processo de obtenção é uma polimerização a partir de um precursor monomérico, envolvendo uma dispersão de monômeros em água, formando uma emulsão ou uma solução em solvente orgânico. Após essa operação, a solução formada contendo a borracha é submetida a um processo de secagem até a obtenção do produto final.

O requisito básico para que um monômero possa ser polimerizado e transformado em borracha, é a existência de ligação dupla em sua composição química, na qual dois átomos de carbono compartilham 2 pares de elétrons. No processo de polimerização ocorre a quebra da ligação, etapa conhecida como iniciação. Após o rompimento da ligação, os elétrons não são mais compartilhados, formando radicais livres, conforme Figura 20.

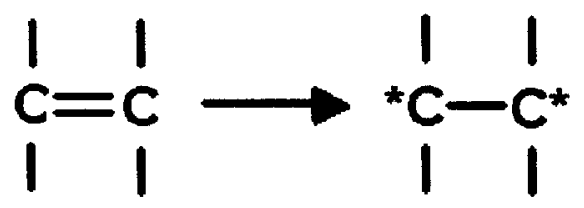

Figura 20 - llustração da formação de radicais livres

A configuração formada permite que a etapa de propagação se inicie, esta é a fase em que novos radicais são unidos aos radicais iniciais, formando cadeias longas. O tamanho das cadeias formadas pode ser controlado pela última etapa do processo de polimerização, a fase chamada de terminação, 
que tem a função de interromper a formação de radicais livres nas extremidades das cadeias longas.

As borrachas sintéticas apresentam insaturações em suas cadeias químicas, isto é, têm ligações duplas que permitem uma vulcanização ou cura, analogamente à borracha natural. Essas ligações cruzadas que podem ser formadas com a presença da ligação dupla vão conferir ao material uma alta elasticidade sem deformação permanente, característica típica de materiais elastoméricos.

Atualmente a indústria química disponibiliza no mercado uma grande variedade de borracha sintética. Alguns exemplos são:

- SBR - copolímero de butadieno-estireno (a principal aplicação é na indústria de pneus);

- BR - polibutadieno (aplicação em pneus na forma de blenda com NR ou SBR devido à boa resistência a abrasão);

- T - borracha de polisulfeto (excelente resistência a solventes orgânicos).

Mais da metade da produção mundial de borracha sintética é consumida pela indústria de pneus, a outra metade é utilizada para produzir uma enorme gama de artefatos (peças para indústria automobilística, adesivos, brinquedos, etc).

Nas figuras $21,22,23$ e 24 estão alguns dados estatísticos ${ }^{(7)}$ que mostram a distribuição mundial das regiōes que mais produzem e consomem borracha sintética. 
PRODUÇÃo MUNDIAL DE BORRACHA SINTÉTICA EM 2001

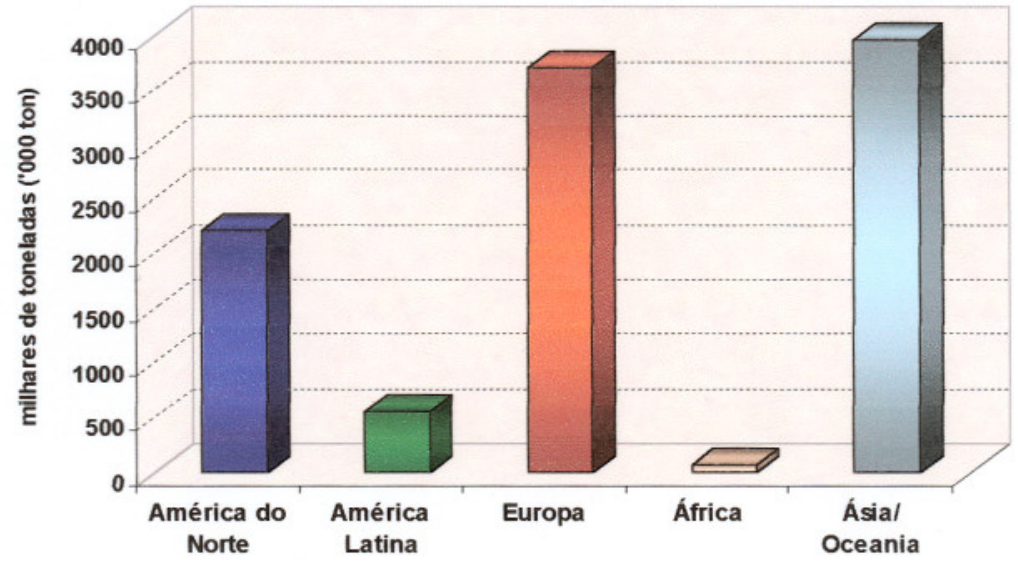

Figura 21 - Distribuição da produção mundial de borracha sintética ${ }^{(7)}$

DISTRIBUIÇÃO DA PRODUÇÃo MUNDIAL DE BORRACHA SINTÉTICA EM 2001

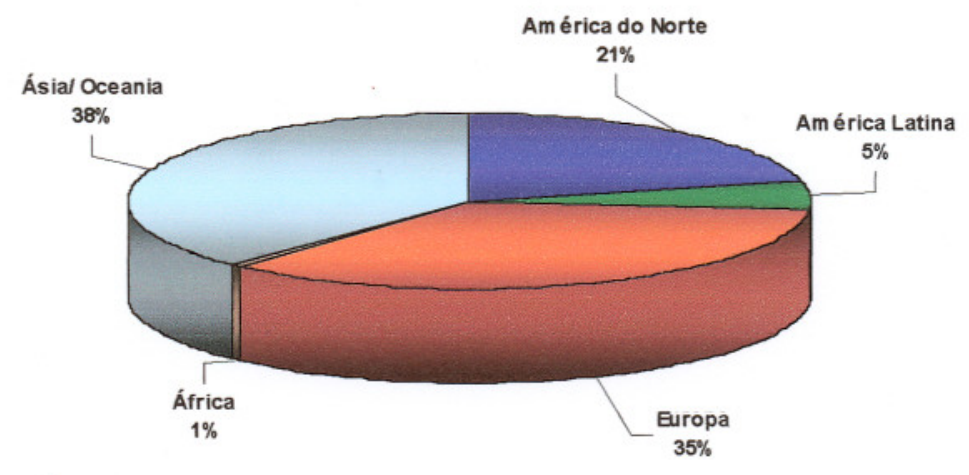

Figura 22 - Distribuição da produção mundial de borracha sintética ${ }^{(7)}$ 


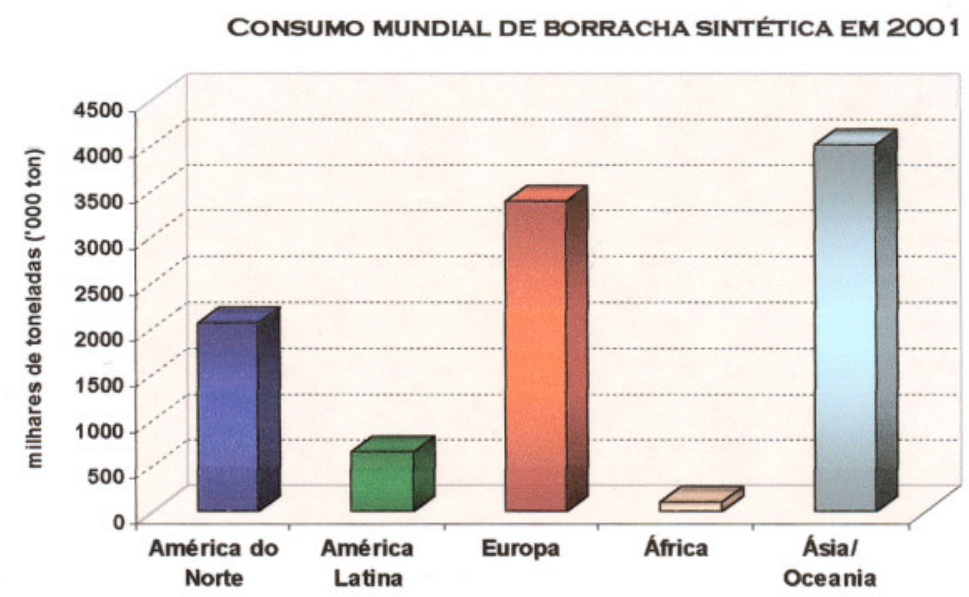

Figura 23 - Distribuição do consumo mundial de borracha sintética ${ }^{(7)}$
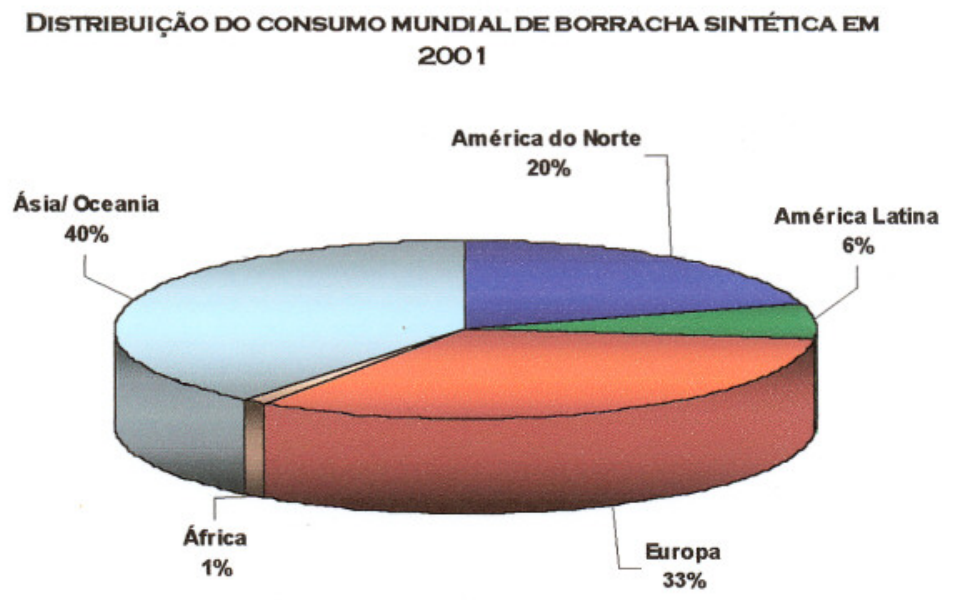

Figura 24 - Distribuição do consumo mundial de borracha sintética ${ }^{(7)}$

$\mathrm{Na}$ Tabela 03, pode-se observar uma comparação entre os processos de obtenção das borrachas natural e sintética. 
Tabela 03 - Processos produtivos de borrachas

\begin{tabular}{|c|c|c|}
\hline & BORRACHA NATURAL & BORRACHA SINTÉTICA \\
\hline Matéria-prima & Luz solar, água, $\mathrm{CO}_{2}$ & Monômeros \\
& Árvore com pelo menos seis anos até & Catalisadores \\
\hline Equipamento & 25 anos & Reatores \\
\hline Processo principal & A própria árvore & Polimerização \\
\hline Produto intermediário & Corte/ Extração & Borracha em solução \\
\hline Etapa final & Látex coagulado & Secagem \\
\hline Produto final & Secagem & BORRACHA SINTÉTICA \\
\hline
\end{tabular}

\subsubsection{Antioxidante}

As borrachas sintéticas e naturais apresentam insaturação, isto é, a presença de ligações duplas, sujeitas à oxidação. Esse tipo de ataque ao material pode levar à cisão da cadeia polimérica, prejudicando as propriedades do produto. Esta oxidação tem uma maior intensidade quando o material é exposto a altas temperaturas ou à luz ultravioleta (UV). Conseqüentemente, é necessária a inclusão de aditivos antioxidantes para prevenir esta perda de propriedade.

Esses aditivos devem ser selecionados considerando as condições finais da aplicação do elastômero, geralmente são formados por compostos a base de aminas, tipo fenólico (estes têm boa proteção ao UV e luz solar), entre outros. 


\subsubsection{Tatificantes}

Para que os adesivos sensíveis à pressão apresentem uma boa performance é necessário ter um balanceamento entre as três principais propriedades: resistência ao destacamento, poder de coesão e tato superficial. Um elastômero apresenta relativamente baixo tato superficial, isto é, sensação de pouca aderência quando tocado. Conseqüentemente, é necessária a adição de materiais que conferem a propriedade de tato superficial ao adesivo. Esses aditivos são conhecidos como tatificantes, e são divididos em três principais classes:

- Breu

- Resinas terpênicas

- Resinas hidrocarbônicas

\subsubsection{Breu}

Breu é uma resina polimérica termoplástica ácida, obtida a partir de árvores do tipo pinheiro (Pinnus). É composto basicamente por uma mistura de ácidos orgânicos. Existem três classes desta resina: breu goma, breu vegetal e Tall Oil.

Breu Goma: obtido diretamente da árvore junto com a terebintina (resina extraída de plantas da família dos pinheiros) na forma de um produto oleoso. Ácido sulfúrico é usualmente empregado para aumentar o rendimento da extração. Esse óleo obtido é destilado para formar o breu goma. 
Breu Vegetal: obtido através de árvores envelhecidas, as quais são descascadas, lavadas e reduzidas à forma de cavaco. Esses são imersos em solventes, ocorrendo a extração da resina e, por fim, através da destilação se obtém o breu vegetal.

Tall Oil: ou conhecido como óleo de Tungue, é produzido através dos cavacos de madeiras, que são subprodutos da indústria madeireira. Esses resíduos são acidificados, formando uma mistura de ácidos graxos e resinas ácidas, assim, se produz o breu tipo Tall oil.

Os componentes ácidos do breu podem sofrer reaçōes posteriores de oxidação na ligação dupla através do contato com $\mathrm{O}_{2}$ ou com outros agentes oxidantes. Devido a essas modificações, há uma grande variedade de breus modificados através de dimerização, hidrogenação e esterificação. Toda essa diversidade pode ser utilizada em adesivos sensiveis à pressão a base de borracha objetivando melhorar as propriedades de tato superficial. As várias composições desses materiais apresentam diferentes pontos de amolecimento, uma característica importante a ser considerada na formulação de um adesivo, pois define a temperatura de aplicação final do produto.

\subsubsection{Resina hidrocarbônica}

Tatificantes hidrocarbônicos são resinas de baixo peso molecular derivadas de monômeros obtidos do petróleo, carvão ou madeira. Como esse materiais são polimeros, suas propriedades são determinadas através da composição dos monómeros, métodos de polimerização e do peso molecular. Essas resinas podem ser classificadas quimicamente através do número médio 
de átomos de carbono que constituem cada monômero da molécula: aromáticas (C-9), alifáticas (C-5) e olefinas cíclicas ou terpênicas (C-5) 2 .

\subsection{Resina hidrocarbônica aromática}

Esses materiais são derivados do petróleo puro ou do piche e têm em média 9 átomos de carbono em cada monômero (C-9). Podem ser obtidos em diferentes pontos de amolecimento, variando de $10^{\circ} \mathrm{C}$ a $150{ }^{\circ} \mathrm{C}$. O peso molecular médio desses tatificantes está na faixa de 290 a 1150 . Uma característica importante é a sua excelente compatibilidade com elastômeros sintéticos. A figura 25 ilustra algumas fórmulas químicas dos monômeros encontrados nessas resinas aromáticas.
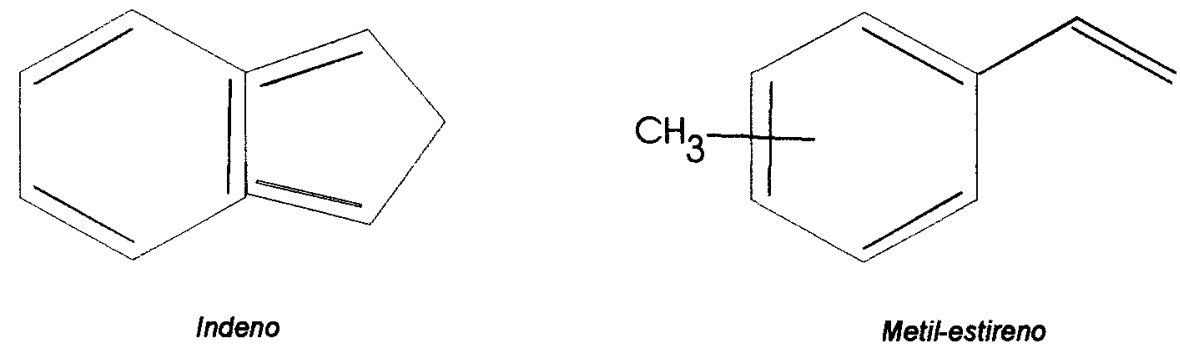

Figura 25 - Resinas tatificantes aromáticas

\subsection{Resina hidrocarbônica alifática}

Essas resinas são derivadas de frações de petróleo puro e têm em média 5 átomos de carbono em cada monômero (C-5). Geralmente são encontradas comercialmente em pontos de amolecimento variando de $80{ }^{\circ} \mathrm{C}$ a 
$115^{\circ} \mathrm{C}$. O peso molecular médio desses tatificantes está na faixa de 1000 a 1500, superiores aos encontrados nas resinas aromáticas. Apresentam excelente estabilidade térmica e cores translúcidas. A figura 26 ilustra as fórmulas químicas dos principais monômeros encontrados nessas resinas aromáticas.
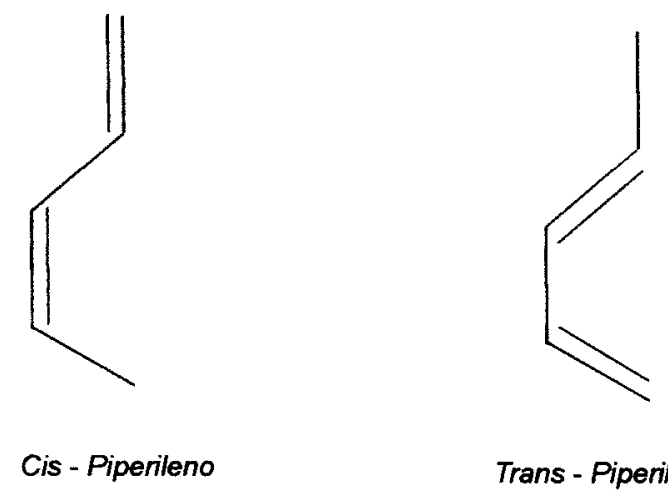

Trans - Piperileno

Figura 26 - Resinas tatificantes alifáticas

\subsection{Resina terpênica}

Esses materiais são derivados do petróleo ou da polimerização de matérias-primas obtidas de fontes naturais, como a terebintina. Os monômeros utilizados na obtenção dessas resinas são dienos ou isoprenos (C-5) 2 . Podem ser obtidos com diferentes pontos de amolecimento, variando de $10^{\circ} \mathrm{C}$ a 140 ${ }^{\circ} \mathrm{C}$. O peso molecular médio desses tatificantes está na faixa de 300 a 2000 . A figura 27 ilustra algumas fórmulas químicas dos monômeros encontrados nessas resinas terpênicas. 

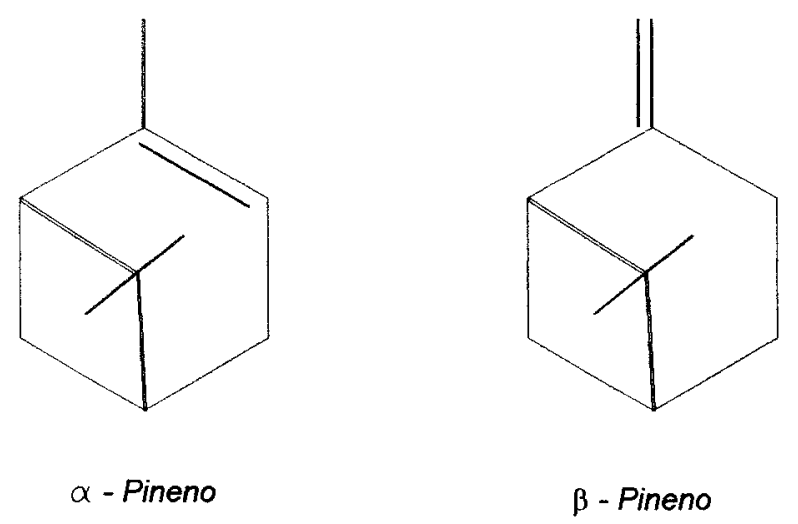

Figura 27 - Resinas tatificantes terpênicas

\subsubsection{Escolha do tatificante}

Conforme já mencionado anteriormente, os adesivos sensíveis à pressão necessitam um balanceamento entre as três principais propriedades; resistência ao destacamento, poder de coesão e tato superficial, para que tenham uma boa performance. Muitos estudos são feitos para determinar o tipo e a concentração de resinas tatificantes para atingir o melhor balanceamento de propriedades.

O trabalho realizado por Wetzel ${ }^{(8)}$ e Wetzel \& Alexander ${ }^{(9)}$ mostra o efeito da concentração e do ponto de amolecimento (alto e baixo) nas propriedades de tato de um adesivo a base de borracha. As resinas testadas no estudo das referências ${ }^{(8,9)}$ foram do tipo Breu. A Figura 28 mostra que o aumento da quantidade (de $20 \%$ a $40 \%$ ) de tatificantes não reflete em um aumento significativo do tato, porém, com mais um pequeno aumento da quantidade de resina ocorre um aumento expressivo da propriedade de tato, chegando a um ponto máximo (para uma concentraçăo de $50 \%$ a $75 \%$ ). Também se observa que resinas de baixo ponto de amolecimento (por 
exemplo; menor que $95^{\circ} \mathrm{C}$ ) conferem valores maiores para a propriedade de tato do que com resinas de alto ponto de amolecimento.

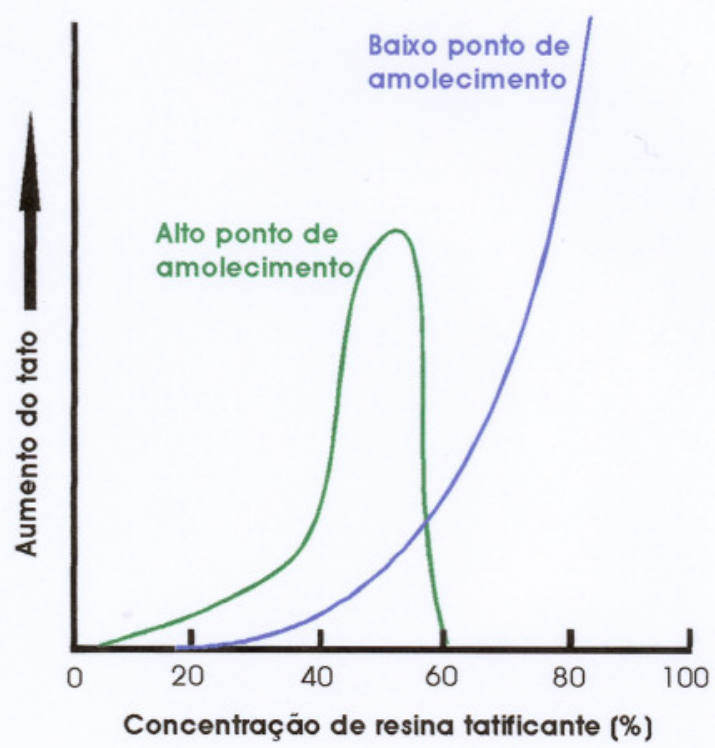

Figura 28 - Gráfico do efeito da quantidade de tatificante na propriedade de tato ${ }^{(8,9)}$.

Entretanto, a propriedade de tato é apenas uma das características importantes de um adesivo a base de borracha. Como visto acima, resinas de baixo ponto de amolecimento conferem boas propriedades de tato, porém, devido à baixa viscosidade, não conferem boas propriedades de coesão. Logo, deve-se fazer um balanceamento correto dos tipos e quantidades de tatificantes para que as propriedades desejadas do adesivo sejam alcançadas.

Na Figura 29 pode-se observar um exemplo ${ }^{(10)}$ do balanceamento das propriedades em função da concentração de resina tatificante do tipo hidrocarbônica em um adesivo sensível à pressão composto por borracha natural. 


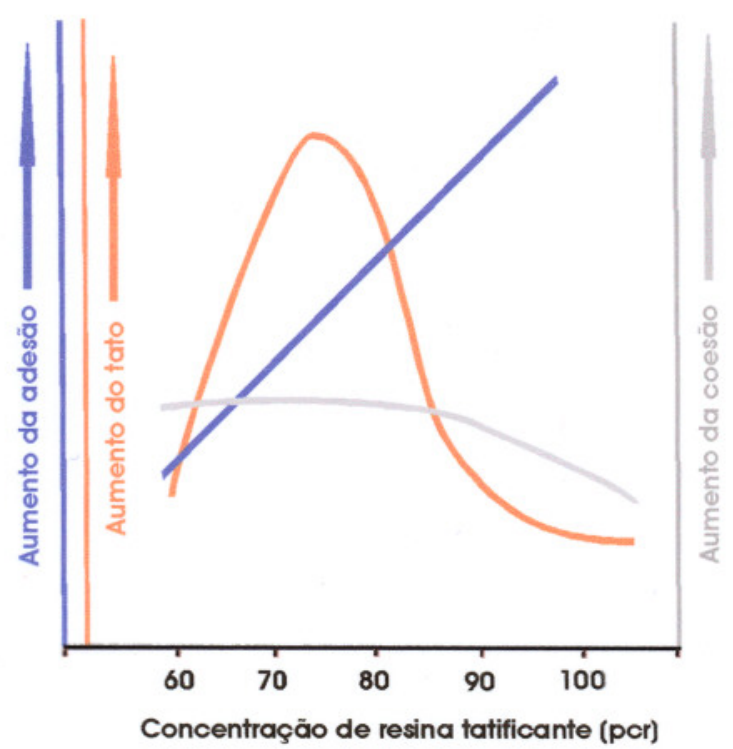

Figura 29 - Gráfico do efeito da quantidade de tatificante em tato, adesão e coesão ${ }^{(10)}$.

Como pode ser observado, o melhor balanceamento das propriedades é alcançado com uma concentração de resina tatificante de aproximadamente 80 pcr, onde este significa partes em massa (Kg, g, mg e etc) para cada 100 partes, também em massa, de borracha.

\subsubsection{Resinato de Zinco}

É uma classe de material obtida através da mistura do breu vegetal, descrito no item 2.8.3.1, ou seu extrato, com óxido de zinco ( $\mathrm{ZnO}$ ). É uma resina muito utilizada na fabricação de colas e adesivos com base de borracha, pois atua como catalisador da formação de ligações cruzadas, ou vulcanização, das borrachas que apresentam duplas ligações. 


\subsubsection{Resina fenólica}

São materiais obtidos a partir da condensação de fenóis $\left(\mathrm{C}_{6} \mathrm{H}_{5} \mathrm{CH}\right)$ e aldeídos do tipo formaldeído ( $\mathrm{HCHO}$ ). A natureza química do fenol e do aldeído utilizados, o tipo e a quantidade de catalisador, o tempo e a temperatura de reação influenciam diretamente nas propriedades da resina fenólica obtida. Um dos principais parâmetros de controle da fabricação desses materiais é a razão entre a quantidade de fenol e formaldeído. Essas resinas são encontradas sob duas formas, resinas RESOL, ou de um estágio, onde existe um excesso de formaldeído sobre a quantidade de fenol; e resinas NOVALACA, ou de dois estágios, onde existe um excesso de fenol sobre a quantidade de formaldeído.

Resinas fenólicas são adicionadas a adesivos sensíveis à pressão a base de borracha para que ocorra um processo de formação de ligação cruzada, obtido a partir da ligação dupla existente na borracha. Essa cura eleva a resistência ao calor do adesivo e aumenta a resistência ao cisalhamento. Porém, um alto grau de ligações cruzadas pode prejudicar a capacidade de adesão $^{(10)}$.

\subsubsection{Cargas}

São materiais, minerais ou não-minerais, inertes ou não-inertes, que quando adicionados ao adesivo podem ter como função: reforçar o composto, pigmentação, intensificar o processo de cura ou vulcanização e a função de enchimento. 
Cargas como talco, carbonato de magnésio, carbonato de cálcio e caulim, geralmente são adicionadas ao composto com o objetivo de reduzir o custo (enchimento) do produto. Porém, quando adicionados em grandes quantidades, esses materiais podem reduzir o tato do adesivo e aumentar a dureza. Também podem aumentar a força de coesão, dependendo da quantidade e da composição.

Dióxido de titânio e negro de fumo (carga não-mineral) são exemplos de cargas que podem ser utilizadas como corantes, isto é, conferem uma coloração ao adesivo. Para o primeiro, a cor obtida é o branco, e para o negro de fumo a coloração final do produto é preta. Muitas vezes o óxido de zinco (ZnO) é utilizado como carga em adesivos sensíveis à pressão a base de borracha, devido a sua capacidade de ativar o processo de cura ou vulcanização, além de atuar como reforço, pigmentação e enchimento.

Para formulações de adesivos que serão utilizados em aplicações de isolamento elétrico, deve-se selecionar uma carga que tenha propriedades como condutividade elétrica, por exemplo, compatíveis com a aplicação final do produto.

\subsubsection{Solventes}

$\mathrm{Na}$ indústria de materiais adesivos, refere-se a solvente como um líquido volátil que permite a dissolução do composto (borracha mais aditivos), reduzindo a viscosidade e formando uma solução que possa ser aplicada ou revestida sobre um determinado substrato. Na maioria das aplicações o solvente é extraído através da evaporação após a aplicação ou uso do adesivo. 
Esse processo de extração pode ocorrer através de várias técnicas, dentre as quais estão: aquecimento com auxílio de estufas e secagem ao ar.

Do ponto de vista químico ${ }^{(12)}$, esse materiais podem ser divididos entre grandes familias de solventes: água, hidrocarbonetos alifáticos e aromáticos, álcoois, ésteres acéticos, cetonas, solventes nitratos e sulfatados, clorados e clorofluorados, frações petroliferas e solventes diversos. Esses produtos se diferenciam pelo poder de solubilidade, volatilidade, odor, cor, toxidez, estabilidade, inflamabilidade, custo, entre outros fatores.

Para que seja possível a aplicação ou o revestimento de adesivos sensiveis à pressão sobre substratos, solventes são utilizados para reduzir a viscosidade final do produto. Para grande parte dos adesivos a base de borracha, os solventes mais utilizados são hidrocarbonetos e cetonas.

Hidrocarbonetos são produtos não-polares, que se comportam como solventes de baixa eficiência em relação aos produtos polares. Distinguem-se duas grandes classes de hidrocarbonetos: os alifáticos (exemplos: hexano e heptano) e os aromáticos (exemplos: benzeno e tolueno).

Fracões petrolíferas provêm essencialmente da destilação do petróleo e se dividem em dois grupos: alifáticos (que são as gasolinas e os querosenes) e aromáticos (solventes do grupo da nafta). Todos esses solventes são classificados por intervalo de destilação e cada produtor define as propriedades e suas especialidades.

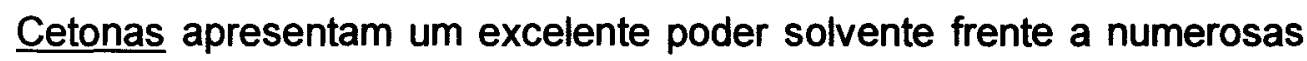
resinas naturais e sintéticas, assim como boa estabilidade química. São divididas em dois grupos: alifáticas (exemplo: acetona e metiletilcetona) e aromáticas (exemplos: acetofenona e benzofenona). 
Na maioria das aplicações, os fatores mais relevantes para a escolha de solventes para a aplicação em adesivos à base de borracha são: capacidade de solubilidade, propriedades toxicológicas favoráveis, possibilidade de recuperação do solvente, ponto de evaporação $\left({ }^{\circ} \mathrm{C}\right)$ dentro de um limite ideal para a aplicação e baixa flamabilidade. Também é comum a utilização de uma mistura de solventes para se obter todas as propriedades necessárias ao produto.

\subsection{Método de Processamento}

O processamento da grande maioria dos adesivos a base de borracha sensível à pressão consiste basicamente na dissolução dos ingredientes sólidos em um solvente apropriado. As borrachas devem sofrer, previamente, um processo de mastigação e incorporação de cargas, caso essas pertençam à formula do adesivo, antes de serem submetidos à mistura final.

Após a etapa de mastigação e incorporação de cargas, os outros ingredientes podem ser adicionados à mistura e dissolvidos em solvente através de diversos equipamentos: batedeira, batedeira planetária, reatores, misturadores tipo sigma, entre outros.

\subsubsection{Mastigação da borracha e incorporação de aditivos}

Elastômeros necessitam de uma viscosidade ideal para que outros ingredientes possam ser facilmente adicionados e dispersos, formando uma mistura uniforme. Para que esta condição seja atingida, as borrachas são 
submetidas aos processos de mastigação. Nestes, altas forças de cisalhamento são aplicadas ao material, geralmente a temperaturas baixas (próximas do ambiente), que causa uma quebra das ligações químicas, reduzindo o peso molecular médio e conseqüentemente a viscosidade.

Existem vários processos que submetem os elastômeros à mastigação. Dentre os mais utilizados estão o moinho de dois rolos e o misturador interno.

\subsubsection{Moinho de dois rolos}

Este equipamento é constituído basicamente por dois cilindros metálicos dispostos horizontalmente, que giram com velocidades periféricas diferentes, formando uma configuração convergente que causa uma fricção ao material. A distância $(H)$ entre esses dois rolos determina o grau de cisalhamento que será dado ao material. Geralmente esses cilindros possuem canais internos pelos quais circulam-se fluídos para aumentar a temperatura superficial do rolo ou diminui-la durante o processamento do elastômero. A Figura 30 exemplifica o funcionamento de um moinho de dois rolos.

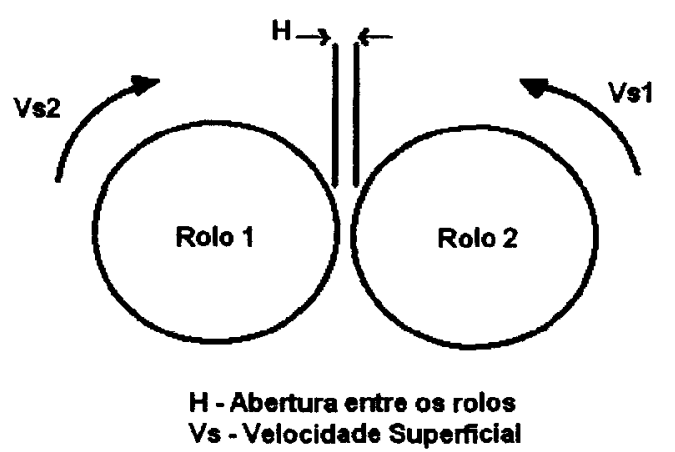

Figura 30 - llustração de um moinho de dois rolos 
Na Figura 31 é apresentada uma fotografia de um equipamento deste tipo.

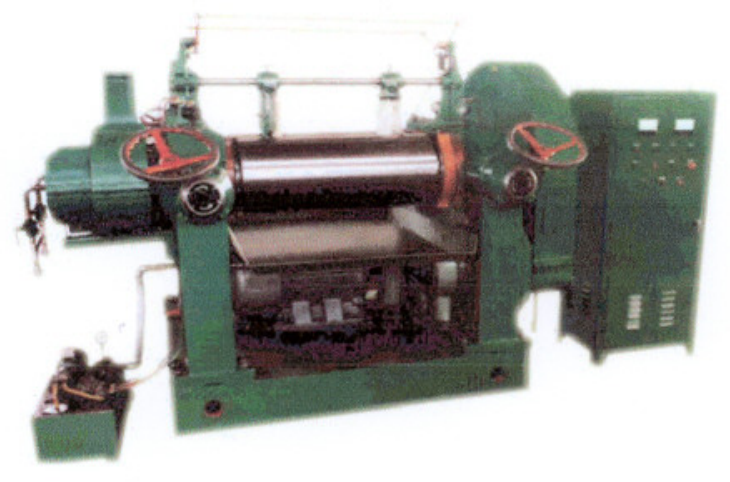

Figura 31 - Foto ilustrativa de um moinho de dois rolos

O processamento de borrachas através do uso de moinho consiste basicamente em deixar os materiais (borracha e aditivos) passarem entre 0 espaço formado entre os cilindros por um tempo determinado. Quanto maior esse tempo, maior será a cisão das cadeias moleculares. Conseqüentemente, menor será a viscosidade do produto obtido, e melhor a homogeneidade do composto formado.

\subsubsection{Misturador Interno}

Este tipo de equipamento é constituído basicamente por uma câmara que contém dois rotores internos, dentro da qual o material é adicionado para sofrer forças cisalhantes. Apresenta uma abertura superior, utilizada para a adição dos materiais e uma abertura inferior para a descarga do composto após o processamento. Existem modelos com um pistão (conhecido como martelo) que tem a função de comprimir o material dentro da câmara. 
Os rotores giram no sentido convergente e podem apresentar configurações variadas que vão conferir diferentes forças cisalhantes ao composto. Também podem conter canais internos que permitem a circulação de fluidos para refrigeração ou aquecimento. A câmara geralmente possui uma camisa que também permite a circulação de fluidos. A Figura 32 exemplifica o funcionamento de um misturador interno.

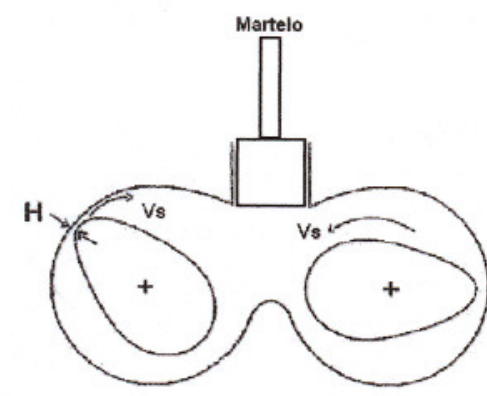

Rotores tipo năo entrelaçado

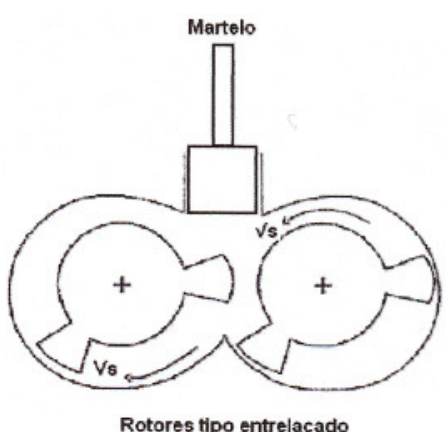

Rotores tipo entrelaçado

$$
\text { H- distância entre a cåmara e o rotor }
$$

Vs - velocidade superficial

Figura 32 - Ilustração de um misturador interno

A Figura 33 ilustra um equipamento do tipo misturador interno.

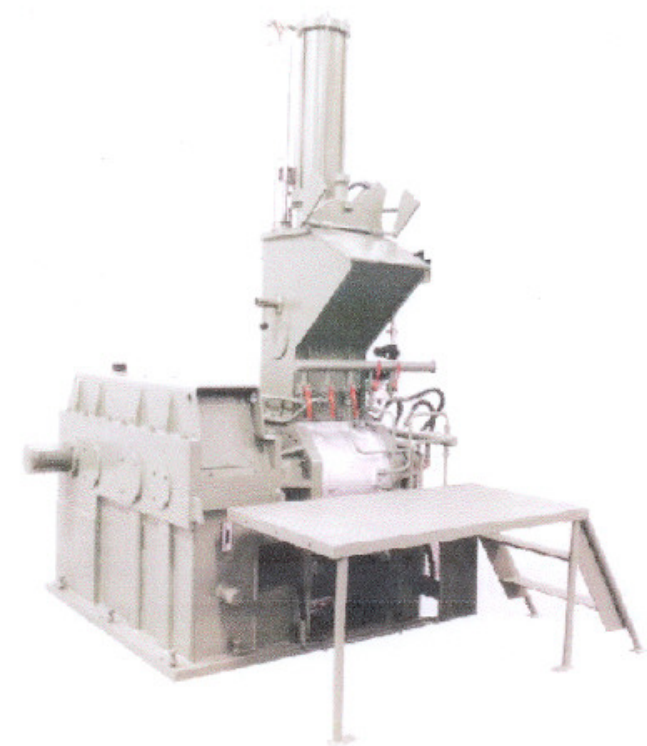

Figura 33 - Foto ilustrativa de um misturador interno 
O processamento de borrachas através do misturador interno consiste basicamente na adição dos materiais (borrachas e aditivos) pela abertura superior, deixando-os sofrer forças cisalhantes por um período, rotação, temperatura da câmara e pressão do pistão previamente determinados. Após o ciclo completo o material é descarregado por uma abertura inferior.

\subsubsection{Mistura e dissolução}

Após o processo de mastigação das borrachas ocorre a mistura dos outros ingredientes, formando então 0 adesivo. Essa mistura pode ocorrer basicamente de duas maneiras: a seco ou via solução.

- A seco: neste tipo de processamento o composto de borracha e os outros aditivos sólidos são adicionados em um equipamento capaz de homogeneizar a mistura sob condições controladas (temperatura, velocidade de agitação, etc). Após a incorporação total, geralmente obtida quando há a formação de uma única fase, o solvente é adicionado para que a parte sólida seja dissolvida, formando o adesivo.

- Via solução: para este tipo de processamento o composto de borracha é, primeiramente, dissolvido no solvente escolhido. Na maioria das vezes essa borracha é, previamente, picada em pedaços pequenos para que aumente a área de contato (área superficial) com o solvente, favorecendo a solubilidade. Após a dissolução completa, os outros materiais são adicionados e homogeneizados, obtendo-se $o$ adesivo. 


\subsubsection{Batedeira}

É um equipamento de construção simples - um vaso e uma hélice - que é muito utilizado para fabricar adesivos sensíveis à pressão a base de borracha via solução. Normalmente, permitem controle apenas da velocidade de rotação da hélice, a qual pode apresentar diferentes configurações que determinam a eficiência do processo de mistura. A Figura 34 exemplifica esse equipamento.
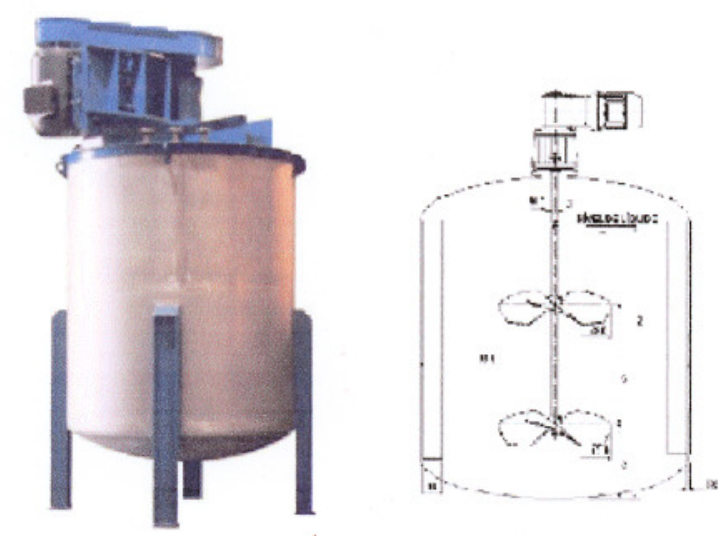

Figura 34 - Foto ilustrativa de uma batedeira

\subsubsection{Batedeira planetária}

É um equipamento similar à batedeira, mas com maior eficiência no processo de mistura dissolução devido à maior agitação aplicada. Pode-se obter uma boa homogeneização dos adesivos em um menor tempo que com a batedeira. Na Figura 35 está um exemplo de batedeira planetária. 


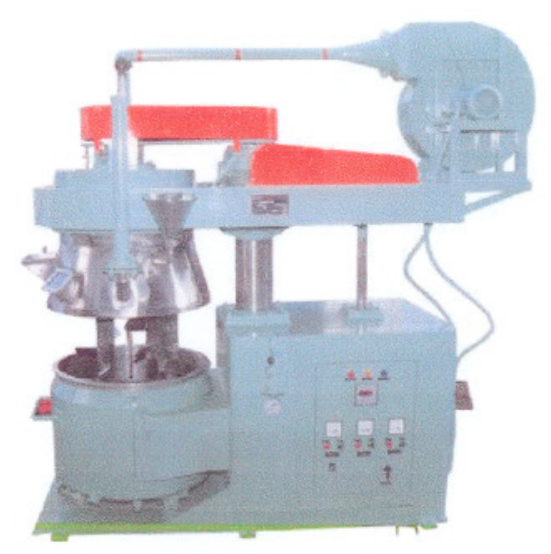

Figura 35 - Foto ilustrativa de uma batedeira planetária

\subsubsection{Reator}

Reator é um equipamento que pode ser utilizado para produzir adesivos sensíveis à pressão a base de borracha via solução. Apresenta um bom controle das variáveis de processamento como temperatura, pressão e velocidade de agitação. Geralmente são escolhidos quando há uma reação envolvida na fabricação do adesivo. Na Figura 36 é mostrada uma ilustração de um reator:

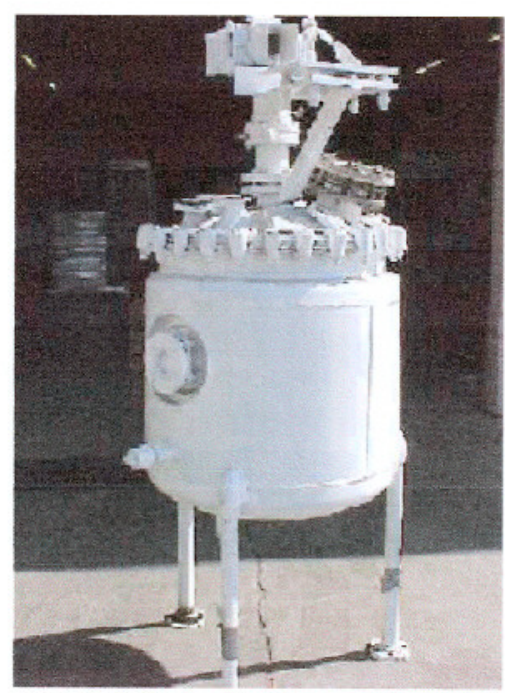

Figura 36 - Foto ilustrativa de um reator 


\subsubsection{Misturador tipo sigma}

É um equipamento de mecânica robusta, formado por dois conjuntos de pás que giram a uma distância mínima de uma câmara de modo a formar um movimento convergente. A rotação do conjunto de pá da frente apresenta uma maior rotação que a pá traseira (de 1.5 a 2 vezes) ${ }^{(5)}$, causando uma fricção ao material, o que facilita a homogeneização e a dissolução. É possível controlar a rotação desses eixos, bem como a temperatura da câmara (aquecimento ou resfriamento). Essas máquinas podem ser encontradas de vários tamanhos, variando de 1 a $4300{ }^{(5)}$ litros de capacidade.

Este tipo de misturador pode ser utilizado para processamento de adesivos sensíveis à pressão a base de borracha a seco devido à sua extrema força. Na Figura 37 está um exemplo de um misturador sigma.

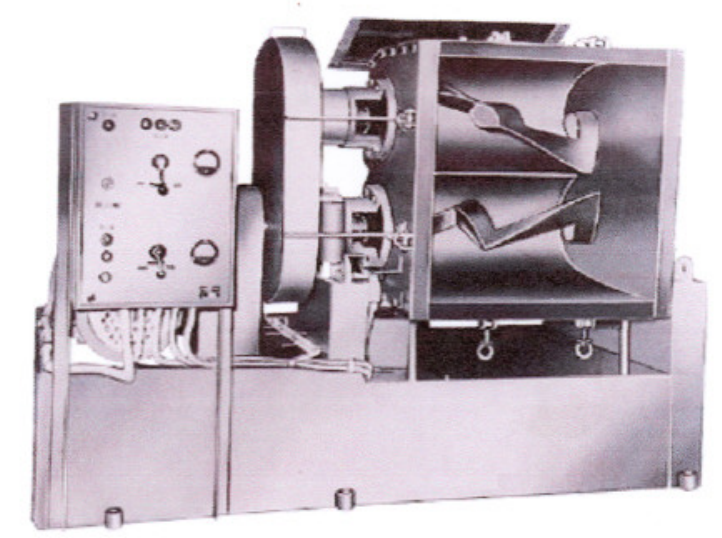

Figura 37 - Foto ilustrativa de um misturador tipo sigma 


\section{MATERIAIS E MÉTODOS UTILIZADOS}

\subsection{Materiais utilizados}

Adesivos sensíveis à pressão baseados em elastômeros geralmente são compostos por uma mistura de borracha e resinas, dissolvida em um solvente apropriado. Neste trabalho foram estudadas três fórmulas distintas: a primeira, utilizada em escala industrial, composta por uma mistura de borracha sintética, borracha natural, antioxidante, resinas tatificantes, resina fenólica e solvente. A variação da formulação número dois está na adição de um óxido metálico. Para a fórmula três, foi considerada a adição de um resinato de zinco. Todas essas alterações foram propostas para evidenciar um possível efeito na formação de ligações cruzadas, o que afeta as propriedades mecânicas do adesivo. $\mathrm{Na}$ Tabela 04 estão expostas as formulações (materiais e proporções) utilizadas neste trabalho.

Tabela 04 - Variação das fórmulas

\begin{tabular}{|c|c|c|c|}
\hline \multicolumn{4}{|c|}{ Variações das formulações } \\
\hline COMPOSIÇÃO (pcr) & \multicolumn{1}{|c|}{ Fórmula 1 } & Fórmula 2 & Fórmula 3 \\
\hline Borracha Natural & 50 & 50 & 50 \\
\hline Borracha Sintética & 50 & 50 & 50 \\
\hline Antioxidante & 1 & 1 & 1 \\
\hline Resina terpênica & 60 & 60 & 60 \\
\hline Resina hidrocarbônica alifática & 30 & 30 & 30 \\
\hline Resina fenólica & 15 & 15 & 15 \\
\hline Óxido de Zinco & - & 5 & - \\
\hline Resinato de Zinco & - & - & 5 \\
\hline
\end{tabular}

$(p c r)^{\star}$ - parte em massa para cada 100 partes em massa de borracha 


\subsection{Processamentos utilizados}

O método de processamento utilizado para a obtenção dos adesivos de escala laboratorial escolhido foi a mastigação das borrachas através de um sistema de moinho de rolos, homogeneização dos materiais sólidos, formação de ligação cruzada (reação da resina fenólica) e solubilização em um misturador tipo sigma. A opção por moinho de dois rolos foi devida à facilidade de operação apresentada por equipamentos com essa configuração, além de ser muito comum encontrar esse tipo de moinho em laboratórios especializados em processamento de borrachas. O misturador sigma foi escolhido por permitir os três processos: 1) homogeneização dos materiais sólidos, 2) aquecimento para ativar a reação da resina fenólica e 3) solubilizar o composto em solvente. Todos esses procedimentos foram realizados no laboratório técnico de produtos elétricos da empresa $3 \mathrm{M}$ do Brasil, que incentivou o desenvolvimento dessa pesquisa.

\subsubsection{Mastigação das borrachas}

O processo de mastigação escolhido para a realização dos experimentos deste trabalho foi o moinho de dois rolos. As condições ajustadas no equipamento foram: abertura entre os rolos de $2,5 \mathrm{~mm}$, circulação de água a $25^{\circ} \mathrm{C}$ no interior dos dois cilindros e rotação padrão do equipamento utilizado (120 rpm). 
O procedimento operacional adotado foi:

1. Moagem da borracha natural e do antioxidante durante $10 \mathrm{~min}$;

2. Adição da borracha sintética e moagem durante $15 \mathrm{~min}$;

3. Adição do Óxido de Zinco (para a fórmula 2) e moagem durante 5 min;

\subsubsection{Mistura e dissolução}

Após 30 min da finalização do processo de mastigação das borrachas, a mistura obtida foi submetida à incorporação dos outros materiais sólidos em um misturador do tipo Sigma, com capacidade de 3,6 litros, rotação das pás de 28 rpm e aquecimento com vapor a uma pressão de $6,0 \mathrm{Kg} / \mathrm{cm}^{2}$.

O procedimento operacional adotado foi:

1. Adição da mistura de borracha após mastigação e adição das resinas tatificantes.

2. Mistura realizada durante $40 \mathrm{~min}$;

3. Aquecimento do sistema até $140^{\circ} \mathrm{C}$ (para ativar a resina fenólica);

4. Adição da resina fenólica;

5. Após o tempo desejado de reação (foi adotado 60 minutos para nível alto e 30 minutos para nível baixo) o sistema foi resfriado à temperatura ambiente, interrompendo a atividade da resina fenólica;

6. Adição do solvente até dissolução completa.

\subsubsection{Nível da reação}


Para cada uma das três fórmulas, descritas no item 3.1, dois experimentos foram realizados: o primeiro, com um alto grau de ligação cruzada e o segundo com um baixo grau de ligação cruzada. Esse nível da reação foi determinado pelo tempo (30 ou 60 minutos): quanto maior o tempo da mistura a $140^{\circ} \mathrm{C}$, maior a quantidade de ligações cruzadas formada.

\subsubsection{Codificação dos experimentos}

Os seis experimentos realizados foram codificados, para melhor entendimento dos resultados que serão apresentados mais adiante, conforme a Tabela 05.

Tabela 05 - Codificação dos experimentos

\begin{tabular}{|c|c|c|c|c|c|c|}
\hline \multicolumn{7}{|c|}{ Codificação dos experimentos } \\
\hline Composição & Fórmula 1 & Fórmula 2 & Fórmula 3 & Fórmula 1 & Fórmula 2 & Fórmula 3 \\
\hline Nível de reação & $\begin{array}{c}\text { Alto } \\
(60 \mathrm{~min})\end{array}$ & $\begin{array}{c}\text { Alto } \\
(60 \mathrm{~min})\end{array}$ & $\begin{array}{c}\text { Alto } \\
(60 \mathrm{~min})\end{array}$ & $\begin{array}{c}\text { Baixo } \\
(30 \mathrm{~min})\end{array}$ & $\begin{array}{c}\text { Baixo } \\
(30 \mathrm{~min})\end{array}$ & $\begin{array}{c}\text { Baixo } \\
(30 \mathrm{~min})\end{array}$ \\
\hline
\end{tabular}

\subsection{Métodos}

\subsubsection{Preparação dos corpos de prova}

Para a realização dos ensaios de adesão ao aço (item 3.3.7.1), adesão ao substrato ou dorso (item 3.3.7.2) e ancoragem (item 3.3.4) recobriu-se um 
filme flexível de PVC (tratado com um "primer" a base de látex) com os adesivos a serem analisados. Já para o teste de resistência ao cisalhamento (item 3.3.5) e grau de ligações cruzadas (item 3.3.6), fez-se o recobrimento de um filme de poliéster.

Para ambos os tipos de filmes o método de recobrimento utilizado consistiu em passar a película por uma abertura existente entre uma base metálica e um rolo fixo (com largura de $300 \mathrm{~mm}$ ) e adicionar o adesivo entre o filme e parte inferior do cilindro. Então, esse filme foi puxado manualmente, formando uma camada de adesivo. A quantidade de adesivo desejada (neste trabalho buscou-se valores próximos a $38 \mathrm{~g} / \mathrm{m}^{2}$ ) foi controlada pela abertura do rolo fixo em relação à base metálica. A Figura 38 ilustra o sistema montado.

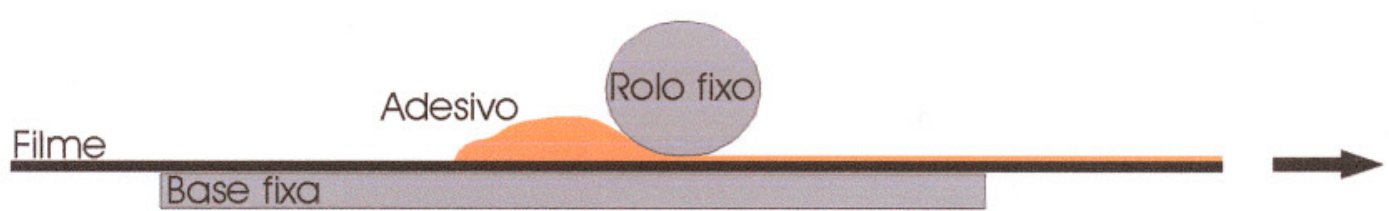

Figura 38 - Montagem para revestimento de substrato com adesivo

Depois de revestido, o conjunto filme e adesivo, tanto para o filme de PVC quanto o filme de poliéster, foi submetido a $100^{\circ} \mathrm{C}$ por $10 \mathrm{~min}$ para efetuar a evaporação do sólvente contido na amostra de adesivo. Após o processo de secagem, foram tiradas três amostras de $100 \mathrm{~mm} \times 100 \mathrm{~mm}$, que foram pesadas e, em seguida, foi retirado o adesivo das mesmas com o auxílio de um pincel e solvente. Calculou-se então a camada de adesivo revestida fazendo, conforme fórmula abaixo:

$$
C R=P C-P F
$$

Onde: 
CR - camada revestida

PC - peso do conjunto (adesivo + filme)

PF - peso do filme (após a retirada do adesivo)

Nas Tabelas 06 e 07 e nas Figuras 40 e 41 temos os resultados da camada de adesivo revestida para as películas de PVC e poliéster, respectivamente.

Tabela 06 - Camada de adesivo revestida no filme de PVC

CAMADA DE ADESIVO REVESTIDA NO FILME DE PVC

\begin{tabular}{|c|c|c|c|c|c|c|}
\hline Experimento & 1A & 2A & 3A & 1B & 2B & 3B \\
\hline Camada de & 36,7 & 39,0 & 37,6 & 35,3 & 41,3 & 39,5 \\
adesivo & 40,2 & 41,0 & 39,6 & 38,3 & 44,7 & 40,8 \\
{$\left[\mathrm{~g} / \mathrm{m}^{2}\right]$} & 36,5 & 42,9 & 33,1 & 32,9 & 45,4 & 42,6 \\
\hline MÉDIA [g/m $\left.\mathbf{m}^{2}\right]$ & $\mathbf{3 7 , 8}$ & $\mathbf{4 1 , 0}$ & $\mathbf{3 6 , 8}$ & $\mathbf{3 5 , 5}$ & $\mathbf{4 3 , 8}$ & $\mathbf{4 1 , 0}$ \\
\hline
\end{tabular}

Um gráfico do tipo "Boxplot" foi utilizado para analisar a variabilidade entre os subgrupos das amostras. Essa figura possui formato retangular e é determinada a partir do máximo valor, do mínimo, primeiro quartil, mediana e terceiro quartil do conjunto de dados, conforme Figura 39. A mediana divide o conjunto de dados em dois, $50 \%$ estão acima deste valor e $50 \%$ abaixo. $\mathrm{O}$ primeiro quartil representa $75 \%$ dos dados e o terceiro quartil $25 \%$ dos dados (19)

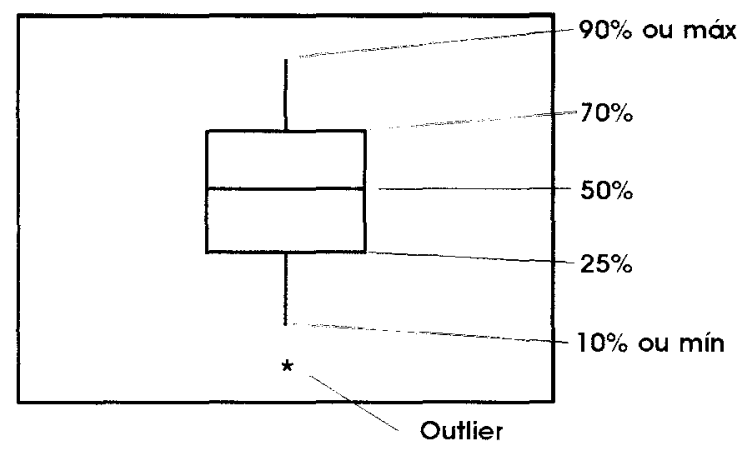


Figura 39 - Exemplo de um gráfico tipo "Boxplot"

Os dados referentes à camada de adesivo revestida no filme de PVC foram inseridos em um gráfico do tipo "Boxplof", conforme Figura 40.

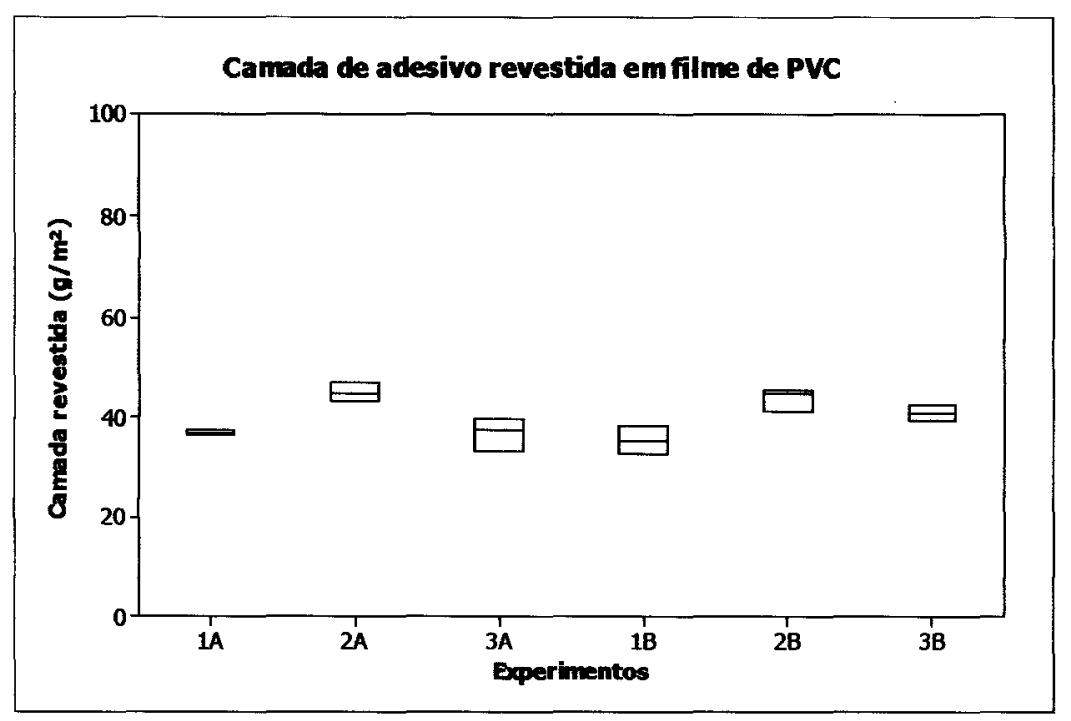

Figura 40 - Gráfico "Boxplot" dos valores da camada de adesivo revestida em PVC

Tabela 07 - Camada de adesivo revestida no filme de Poliéster

CAMADA DE ADESIVO REVESTIDA NO FILME DE POLIÉSTER

\begin{tabular}{|c|c|c|c|c|c|c|}
\hline Experimento & 1A & 2A & 3A & 1B & 2B & 3B \\
\hline Camada de & 36,8 & 33,2 & 35,6 & 38,4 & 34,4 & 31,2 \\
adesivo & 37,6 & 32,8 & 33,2 & 36,4 & 36,0 & 32,0 \\
[g/m $\left.{ }^{2}\right]$ & 36,4 & 32,8 & 34,8 & 36,4 & 34,8 & 33,6 \\
\hline MÉDIA [g/m $\left./ \mathbf{m}^{2}\right]$ & $\mathbf{3 6 , 9}$ & $\mathbf{3 2 , 9}$ & $\mathbf{3 4 , 5}$ & $\mathbf{3 7 , 1}$ & $\mathbf{3 5 , 1}$ & $\mathbf{3 2 , 3}$ \\
\hline
\end{tabular}

Esses dados foram inseridos em um gráfico do tipo "Boxplof", conforme figura 41. 


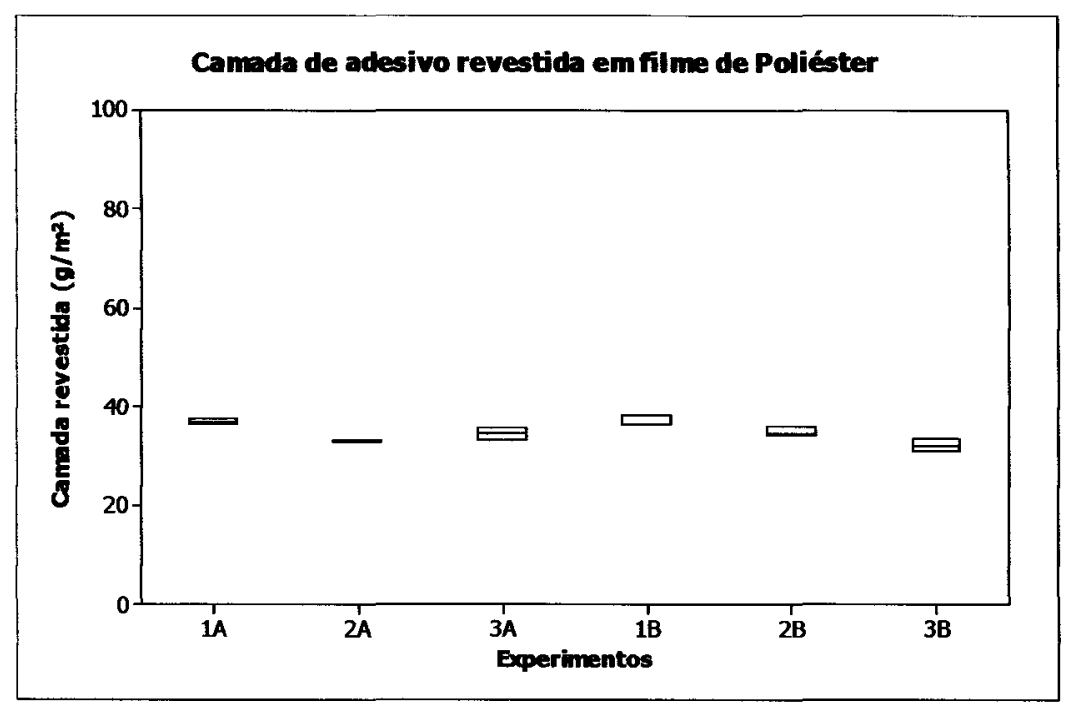

Figura 41 - Gráfico "Boxplot" dos valores da camada de adesivo revestida Poliéster

Percebe-se que os resultados obtidos da camada de adesivo revestida, para os dois filmes, apresentam variações em relação ao objetivo de $38 \mathrm{~g} / \mathrm{m}^{2}$. Isto é fruto do método utilizado e da influência da variação da espessura dos filmes escolhidos. Para o filme de PVC a variação é maior (observa-se que o gráfico do tipo "boxplot" resultou em caixas mais alongadas), pois esse material é proveniente de um processo de calandragem, o qual não confere uma boa precisão na espessura ( $\pm 5 \%$ ). Já para o filme de poliéster o desvio é menor $( \pm$ $2 \%$ ), pois é processado através de extrusão, que permite um bom controle da espessura.

Há estudos na literatura ${ }^{(24)}$ que demonstram que camadas maiores de adesivo levam a maiores valores de aderência até a um ponto máximo. Após esse limite, os resultados não são mais elevados significativamente com o aumento da camada revestida. Na figura 42 há um exemplo de um estudo realizado por Johnston ${ }^{(24)}$ com um adesivo a base de borracha natural e com 
presença de ligações cruzadas, com fórmula muito similar à utilizada neste trabalho. Foi identificado que camadas de adesivo, revestidas em filme de poliéster, superiores a aproximadamente $0,050 \mathrm{~mm}$ levam a valores máximos de aderência.

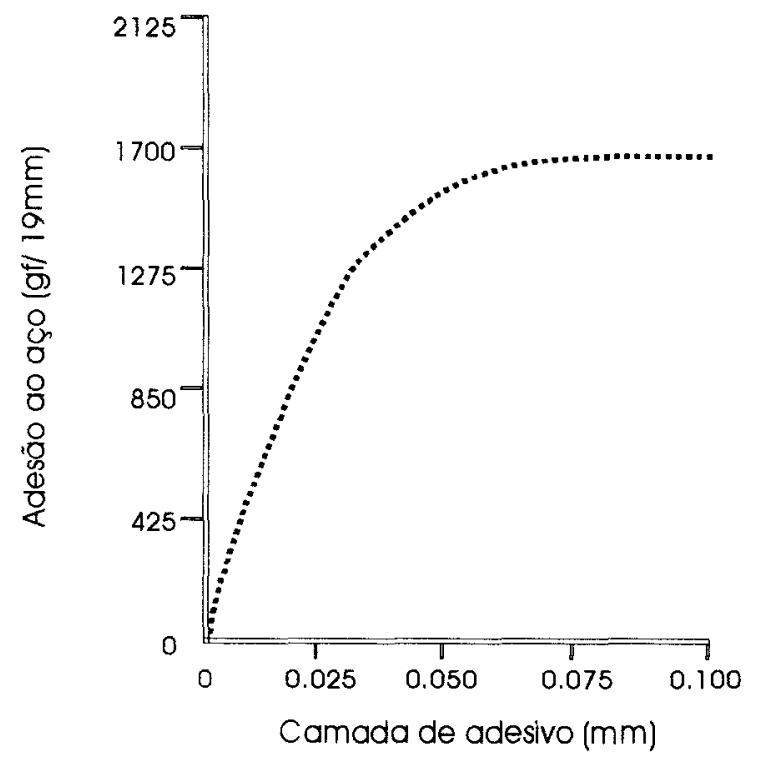

Figura 42 - Efeito da camada de adesivo nos valores de adesão

Neste trabalho, durante a preparação das amostras, buscou-se o valor de $38 \mathrm{~g} / \mathrm{m}^{2}$ da camada revestida através de ajustes da abertura do rolo fixo do equipamento montado em laboratório. Utilizando a definição de densidade ( $\rho)$ para calcular a espessura da camada revestida, chega-se ao valor de aproximadamente $0,049 \mathrm{~mm}$.

$$
\rho=m / V
$$

Onde: 
$\mathrm{m}$ - massa utilizada ( $38 \mathrm{~g}$ para cada $1 \mathrm{~m}^{2}$ ou $0,0038 \mathrm{~g}$ para cada $1 \mathrm{~cm}^{2}$ )

$V$ - volume ocupado no espaço (largura $x$ comprimento $x$ espessura)

$\rho$ - densidade do adesivo $\left(0,78 \mathrm{~g} / \mathrm{cm}^{3}\right)$

Calculando a expressão:

$0,78=0,0038 /(1 \times 1 \times e)$

Logo:

e $=0,049 \mathrm{~mm}$ (espessura da camada revestida)

Conforme demonstrado no estudo realizado de Johnston ${ }^{(24)}$ (com um adesivo similar), valores de revestimento relativamente altos (próximos a 0,050 mm) levam a uma estabilização nos resultados de aderência. Portanto, acredita-se que as variações encontradas na espessura da camada de adesivo revestida em laboratório são aceitáveis e não afetam significativamente os resultados das análises realizadas neste trabalho.

\subsubsection{Viscosidade}

Viscosidade é um parâmetro reológico do material que quantifica a dificuldade de escoamento do mesmo. É uma característica do adesivo que deve ser conhecida para se definir os parâmetros de processamento ou tipo de aplicação. Um adesivo sensivel à pressão geralmente é apenas um material 
intermediário que vai compor um produto final, como uma fita ou um laminado. Portanto, sua capacidade de escoar é fundamental para o processo de aplicação sobre um substrato. Existem processos de recobrimento de adesivos sobre substratos que necessitam de viscosidades extremamente baixas, de 500 a $2000 \mathrm{cps}$. Este é o caso do sistema de cascata, que consiste em, basicamente, escoar o adesivo sobre uma lâmina que está próxima do substrato, formando uma película muito fina de recobrimento, conforme a Figura 43. Esta técnica é utilizada para recobrir camadas pequenas de adesivo, da ordem de 2 a $5 \mathrm{~g} / \mathrm{m}^{2}$.

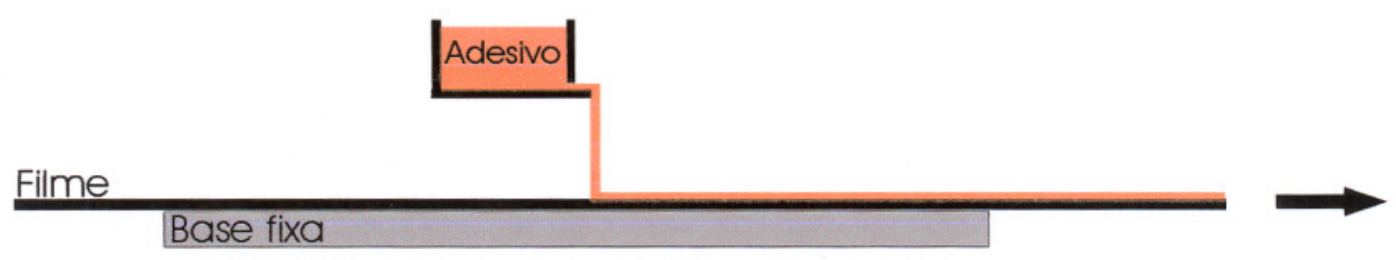

Figura 43 - Ilustração do revestimento tipo cascata

Há outros processos de aplicação, como o tipo rolo ou lâmina, mostrado na figura 38 , que necessitam de viscosidades mais elevadas, da ordem de 10.000 a $40.000 \mathrm{cps}$, para ser viável e revestir camadas de até $50 \mathrm{~g} / \mathrm{m}^{2}$. A viscosidade também representa uma variável importante no processamento quando se leva em consideração a evaporação do solvente para obter o adesivo seco, que geralmente é a forma desejada. Uma maior concentração de solvente leva a uma baixa viscosidade, que pode ser favorável a um revestimento do tipo cascata, porém, pode dificultar o processo de secagem, pois há mais solvente para ser retirado. Logo, percebe-se que a viscosidade é 
um fator de extrema importância, e que deve ser conhecido, para aplicação de adesivos.

\section{Amostragem}

Para as análises dos adesivos preparados neste trabalho foi selecionada uma amostra de cada experimento.

\section{Aparelhagem}

- Viscosímetro Brookfield modelo LV;

- Bastão Brookfield número 4;

- Recipiente para amostra;

- Termômetro.

\section{Procedimento}

Primeiramente a amostra foi mantida a $24^{\circ} \mathrm{C}$ durante $24 \mathrm{~h}$. Então a mesma foi colocada em um recipiente, evitando a formação de bolhas de ar. Em seguida, o bastão padrão número 4 foi introduzido no adesivo, no centro do recipiente. O viscosímetro foi nivelado para que a marca do bastão fosse coberta pela amostra a ser testada. Um termômetro foi introduzido na amostra para determinar a temperatura do material durante a realização do ensaio. A Figura 44 ilustra a montagem realizada para a determinação do valor de viscosidade. 


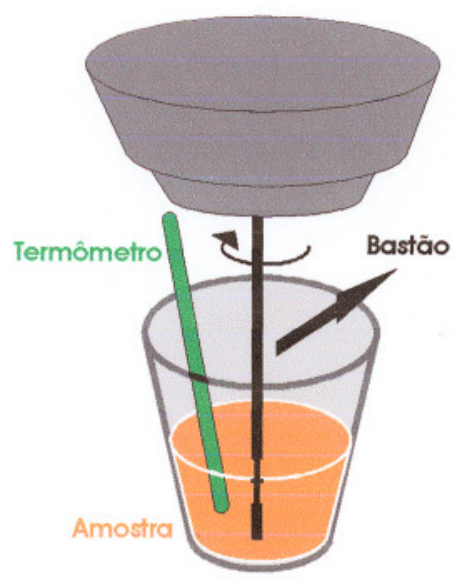

Figura 44 - Ilustração da montagem efetuada para determinação da viscosidade

O equipamento foi ajustado para uma rotação de 12 rpm e então ligado. Após a estabilização do ponteiro marcador a leitura do valor foi efetuada. A viscosidade de cada amostra foi controlada (ajustada) para valores próximos a 6300 cps (centipoises), adicionando solvente, quando necessário, e homogeneizando-o. Isso se fez necessário, pois a viscosidade foi adotada como referência, isto é, as amostras foram fixadas em torno de $6300 \mathrm{cps}$ para que se pudesse entender se outras propriedades físicas e reológicas alteraram, como o percentual de materiais sólidos, por exemplo.

\subsubsection{Percentual de materiais sólidos}

Conhecer o percentual de materiais sólidos presentes na composição do adesivo é muito importante para projetar a camada de adesivo a ser revestida e as condições de secagem do solvente. Um alto percentual de materiais sólidos significa que menos energia será necessária para secar o adesivo, pois a quantidade de solvente é menor, quando comparada com uma amostra de 
baixo teor de sólidos. Porém, alto teor de sólidos significa alta viscosidade, o que pode requerer processos de aplicação mais robustos.

\section{Amostragem}

Para as análises dos adesivos preparados neste trabalho foram selecionadas duas amostras de cada experimento.

\section{Aparelhagem}

- Recipiente de folha de alumínio;

- Lâmpada infravermelha;

- Balança com precisão de 0,001g;

- Base e suporte metálico;

\section{Procedimento}

Fazer a montagem da lâmpada infravermelha a uma distância de $63 \mathrm{~mm}$ da amostra, conformẹ ilustração da Figura 45. 


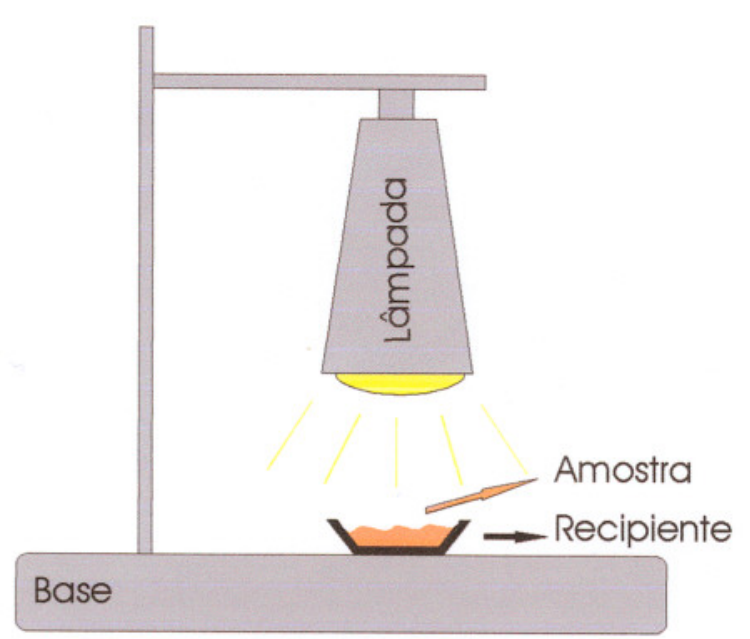

Figura 45 - llustração da montagem efetuada para determinação do teor de sólidos

Pesar o recipiente de alumínio e então coloque aproximadamente $1,0 \mathrm{~g}$ da amostra de adesivo e pese o conjunto (Peso inicial). Em seguida ligue a

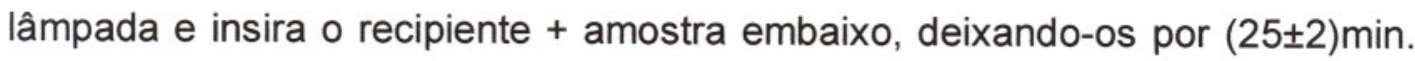
Depois de decorrido o tempo, deixe o conjunto esfriar por 3 min e pese-o novamente (Peso final). Para obter o percentual de sólidos contido na amostra foi utilizada a fórmula:

$\%$ Sólidos $=[$ Peso final - Peso do recipiente $] /$ Peso inicial - Peso do recipiente $] \times 100$

\subsubsection{Ancoragem}

Ancoragem é definida como a força necessária para remover o adesivo do substrato, isto é, mensura a capacidade do adesivo de aderir ao substrato. Na maioria das aplicações busca-se alta força de remoção, ou ancoragem, pois se $\circ$ adesivo se soltar do substrato, os produtos, laminados ou fitas, perdem 
sua função. Neste trabalho, para efeito comparativo entre os adesivos produzidos em escala de laboratório, utilizou-se uma fita padrão de papel posicionada, sob condições padronizadas, sobre o adesivo da amostra a ser analisada e efetuou-se a medida da força necessária para remover a fita padrão.

\section{Amostragem}

Foram selecionadas seis amostras de filme de PVC recoberto com os adesivos, de dimensão $300 \mathrm{~mm} \times 19 \mathrm{~mm}$ cada. Três corpos de prova foram testados logo após o processo de acondicionamento durante $24 \mathrm{~h}$, descrito no item abaixo. Os outros três restantes foram colocados na estufa durante 7dias a $65^{\circ} \mathrm{C}$ e, após esse período, foram acondicionados durante 24 horas e então submetidos ao ensaio.

\section{Aparelhagem}

- Um rolete de metal com peso de 2,15Kg, conforme Figura 50;

- Máquina de tração, conforme Figura 51;

- Placa de aço;

- Fita dupla-face;

- Fita de papel padrão de $12 \mathrm{~mm}$ de largura. 


\section{Corpo de prova}

Três corpos de prova foram retirados do filme de PVC coberto com adesivo (descrito no item 3.3.1) com o auxílio de uma lâmina metálica cortante. Então, os mesmos foram acondicionados durante $24 \mathrm{~h}$ à temperatura de (23 \pm $2)^{\circ} \mathrm{C}$ e a uma umidade relativa de $(50 \pm 5) \%$ antes de serem testados.

\section{Procedimento}

A fita dupla-face foi aplicada no centro de uma placa de aço, em seguida a amostra foi colocada com o lado do adesivo para cima. Então, a fita de papel padrão foi aplicada com o lado do adesivo sobre o adesivo da amostra. Por último, o peso padrão foi passado uma vez sobre o conjunto montado a uma velocidade de $(300 \pm 30) \mathrm{m} / \mathrm{s}$. Nas Figuras 46 e 47 estão ilustradas as montagens efetuadas para a realização deste ensaio:

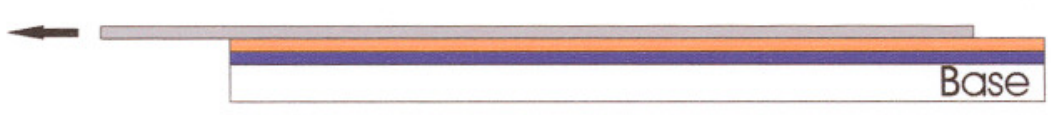

Figura 46 - Ilustração da vista lateral da montagem realizada para ensaio de ancoragem

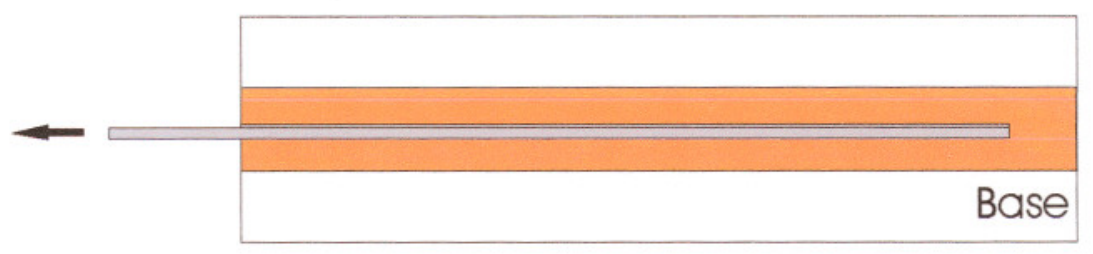

Figura 47 - Ilustração superior da montagem realizada para ensaio de ancoragem 
Depois de efetuada a montagem, um lado da placa foi colocado na garra fixa da máquina de tração e a parte livre do corpo de prova foi fixada à garra móvel, a qual foi posta em movimento a uma velocidade de (300 I 30) $\mathrm{mm} / \mathrm{min}$. O equipamento efetuou leituras da força necessária para remover a amostra da placa de aço. Todo o ensaio foi realizado a $(23 \pm 2)^{\circ} \mathrm{C}$ e a uma umidade relativa de $(50 \pm 5) \%$.

\subsubsection{Resistência ao cisalhamento}

Para este trabalho, foi definida como a capacidade da amostra em resistir a uma força aplicada no sentido longitudinal de dois corpos de prova atados pela superfície revestida com adesivo. Esse ensaio mensura a capacidade da amostra em resistir a forças cisalhantes. Como dito anteriormente, materiais elastoméricos, ou borrachas, são polímeros que apresentam escoamento entre as cadeias poliméricas quando submetidos a esforços. Os PSA apresentam características similares, isto é, escoam quando submetidos a uma força cisalhante. Com esse teste é possível medir qual amostra apresenta uma maior resistência ao cisalhamento, característica que é afetada pela presença de ligações cruzadas.

\section{Amostragem}

Foram selecionadas duas amostras de cada experimento, do filme de poliéster recoberto com adesivo e com dimensão de $250 \mathrm{~mm} \times 12 \mathrm{~mm}$ cada. 


\section{Aparelhagem}

- Estufa a $49^{\circ} \mathrm{C}$;

- Peso padrão de 500g;

- Um rolete de metal com peso de $0,80 \mathrm{Kg}$, similar ao mostrado na Figura 50.

\section{Corpo de prova}

Quatro corpos de prova de $150 \mathrm{~mm} \times 12 \mathrm{~mm}$ foram retirados do filme de Poliéster coberto com cada adesivo (descrito no item 3.3.1) com o auxílio de uma lâmina metálica cortante.

\section{Procedimento}

Dois corpos de prova, do mesmo experimento, foram atados pela superficie com adesivo em uma área de $12 \mathrm{~mm} \times 12 \mathrm{~mm}$. Então, o peso padrão foi passado duas vezes em cada direção sobre o conjunto montado, dando uma pressão necéssária para causar uma boa aderência na região a ser analisada. Em seguida, a parte superior do conjunto foi afixada em um suporte e um peso padrão de $500 \mathrm{~g}$ foi atado à parte inferior. Todo esse conjunto foi colocado dentro de uma estufa a $49^{\circ} \mathrm{C}$ e mediu-se o tempo para que ocorresse a queda do corpo de prova inferior. Este mesmo procedimento foi repetido para as outras duas amostras. A Figura 48 ilustra a montagem para a realização deste ensaio. 


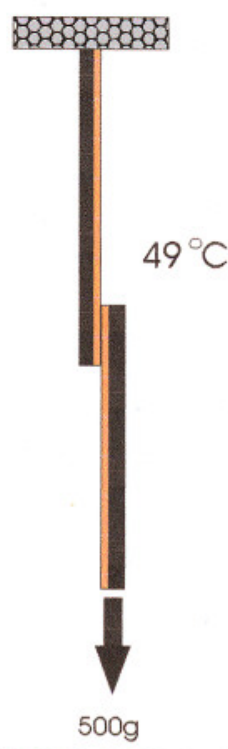

Figura 48 - Ilustração da montagem para ensaio de resistência ao cisalhamento

\subsubsection{Grau de ligações cruzadas}

Elastômeros crus, isto é, borrachas sem a presença de ligações cruzadas, incham quando submetidas a determinados solventes (o que depende de suas características químicas e estruturais). Se o tempo de exposição a esses líquidos for prolongado, todo o polímero pode ser dissolvido, formando uma única fase líquida. Com a inserção de ligações químicas entre as macromoléculas, ocorre uma maior dificuldade de separação das cadeias, logo, uma maior quantidade de ligações cruzadas leva a uma maior resistência

a solventes ${ }^{(5)}$. Com base neste conceito, definiu-se como grau de ligações cruzadas o percentual de material sólido contido no adesivo que não é solubilizado por solvente.

\section{Amostragem}

Foram selecionadas três amostras de cada experimento revestido em filme de poliéster, conforme descrito no item 3.3.1. 


\section{Aparelhagem}

- Solvente Toluol (PA);

- Recipiente para amostra;

- Cesta de malha metálica;

- Balança analítica com precisão de 0,001g.

\section{Procedimento}

Amostras de $50 \mathrm{~mm} \times 50 \mathrm{~mm}$ foram cortadas do filme de Poliéster revestido com o adesivo. As mesmas foram pesadas e então colocadas dentro de cestas feitas com malha metálica, em seguida, uma nova pesagem foi realizada. Então, estes conjuntos foram deixados imersos em Toluol durante 24 horas. Na figura 49 há uma ilustração da montagem efetuada.
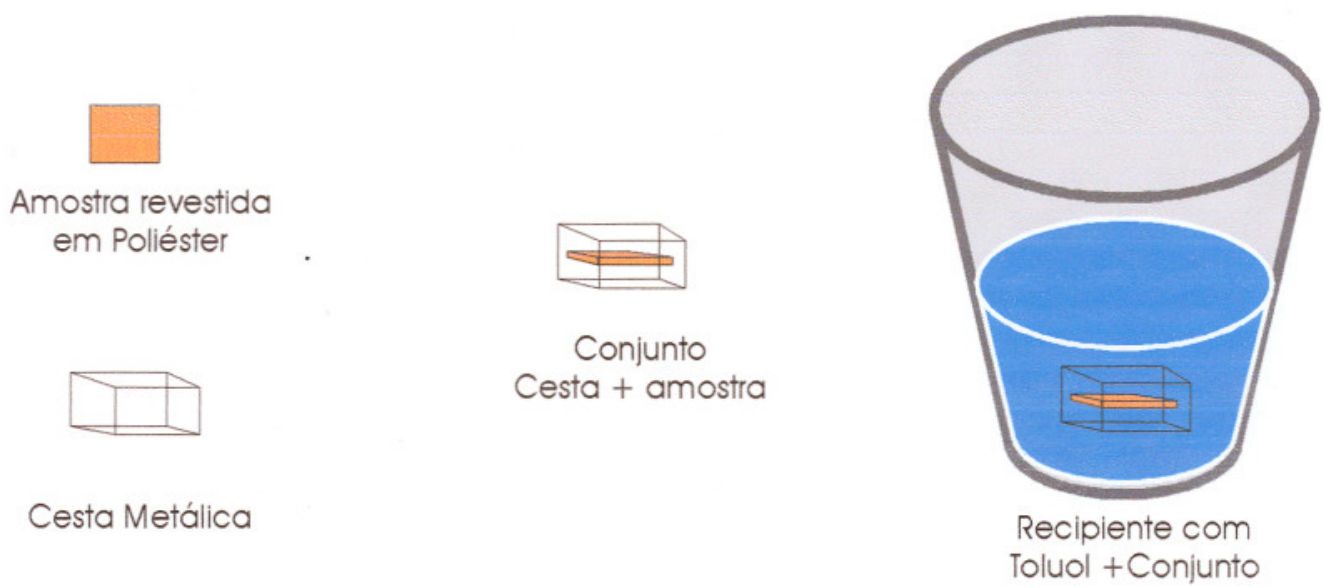

Figura 49 - Ilustração da montagem para determinação do grau de ligações cruzadas 
Depois de 24 horas, as amostras foram cuidadosamente retiradas do recipiente com Toluol e colocadas ao ambiente por 24 horas para que o solvente residual fosse evaporado. Após a secagem, as amostras foram retiradas da cesta e pesadas em uma balança de precisão. Dessa maneira, pode-se determinar o material residual (que não foi dissolvido) contido na cesta.

\subsubsection{Adesão}

\subsubsection{Adesão em superfície metálica}

Adesão em superfície metálica é definida como a força necessária para remover uma amostra de adesivo, revestido sobre um substrato vinílico flexível, aplicada, sob condições padronizadas, sobre uma placa metálica. Também conhecido como ensaio de adesão ao aço. Valores de adesão em superfície metálica auxiliam na determinação do poder de aderência sobre metal, o que ajuda a determinar as condições de aplicação final do produto. Optou-se pelo ensaio de adesão de um produto de substrato vinílico, pois este pode prejudicar propriedades de aderência devido à presença de óleos plastificantes em sua composição. Dessa maneira, ensaios comparativos podem demonstrar qual amostra de adesivo apresenta melhores comportamentos sob condições de migração de óleos sintéticos. O procedimento de teste utilizado para obtenção desses valores foi baseado na NBR 5057 (Norma Brasileira Registrada)/ ABNT (Associação Brasileira de Normas Técnicas). 


\section{Amostragem}

Foram selecionados seis corpos de prova de cada experimento com dimensão de $450 \mathrm{~mm} \times 19 \mathrm{~mm}$ cada. Três deles foram submetidos ao teste de adesão à superfície metálica logo após o processo de acondicionamento durante $24 \mathrm{~h}$, descrito no item abaixo. Os outros três corpos de prova foram colocados na estufa durante 7 dias a $65^{\circ} \mathrm{C}$ e, após esse período, foram acondicionados durante 24 horas e então submetidos ao ensaio.

\section{Aparelhagem}

- Placas de aço inoxidável polido de $200 \mathrm{~mm}$ x $50 \mathrm{~mm} \times 2 \mathrm{~mm}$ cada, com a rugosidade de superfície indicada na NBR6405;

- Um rolete de metal com peso de 2,15Kg, ilustrado na Figura 50;

- Máquina de tração, conforme Figura 51;

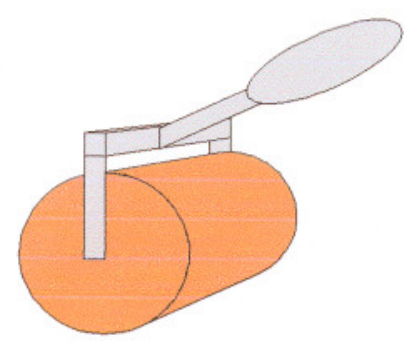

Figura 50 - Ilustração do rolete utilizado nos ensaios de adesão 


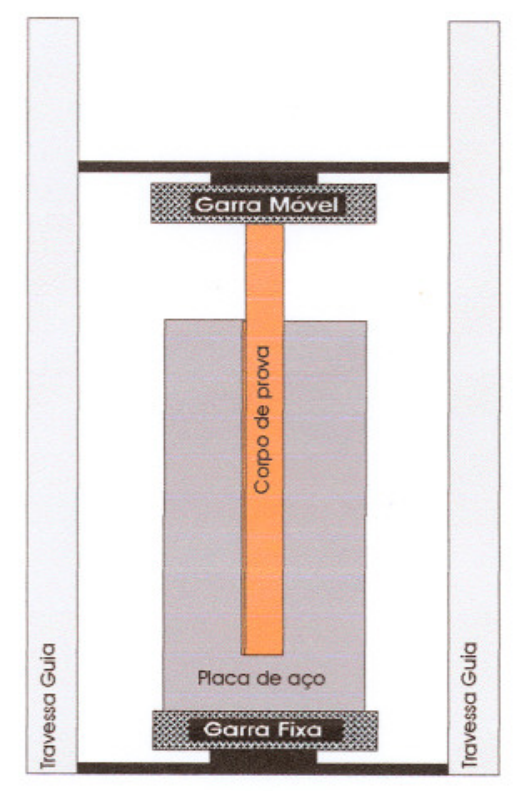

Figura 51 - Ilustração da máquina de tração utilizada para os ensaio de adesão

\section{Corpos de prova}

Os corpos de prova foram retirados do filme de PVC coberto com adesivo (descrito no item 3.3.1) com o auxílio de uma lâmina metálica cortante. Então, os mesmos foram acondicionados durante $24 \mathrm{~h}$ à temperatura de (23 \pm $2)^{\circ} \mathrm{C}$ e a uma umidade relativa de $(50 \pm 5) \%$ antes de serem testados.

\section{Procedimento}

Cada corpo de prova foi colocado com o lado do adesivo sobre a superfície de uma placa de aço, sendo que aproximadamente $250 \mathrm{~mm}$ ficaram fora da placa. Então, o rolete metálico foi colocado sobre o corpo de prova em uma das extremidades da placa e passado quatro vezes (duas vezes em uma direção e duas vezes na outra) com velocidade constante, sem que nenhuma 
pressão manual fosse aplicada. Cada percurso de $200 \mathrm{~mm}$ levou de 10 s a $12 \mathrm{~s}$, tomando-se cuidado de manter o rolete centralizado sobre o corpo de prova. Em seguida, a amostra ficou em repouso por 5 min a $(23 \pm 2)^{\circ} \mathrm{C}$ e a uma umidade relativa de $(50 \pm 5) \%$. Após o acondicionamento, a placa de aço foi colocada na garra fixa da máquina de tração e a parte livre do corpo de prova foi fixada à garra móvel, a qual foi posta em movimento a uma velocidade de (300 \pm 30$) \mathrm{mm} / \mathrm{min}$. O equipamento efetuou leituras da força necessária para remover a amostra da placa de aço em intervalos consecutivos de $12.5 \mathrm{~mm}$. Todo o ensaio foi realizado a $(23 \pm 2)^{\circ} \mathrm{C}$ e a uma umidade relativa de $(50 \pm$ 5)\%.

\subsubsection{Adesão em substrato vinílico}

Adesão em substrato vinílico é definida como a força necessária para remover uma amostra de adesivo, revestido sobre um substrato vinílico flexível, aplicada, sob condições padronizadas, sobre o dorso de uma outra amostra revestida também sobre um substrato vinílico. É importante ter conhecimento do poder de aderência ao dorso, por exemplo, de uma fita vinílica, para que se determine a capacidade do produto de aderir quando enrolado ou aplicado em camadas. Optou-se pelo ensaio de adesão de um produto de substrato vinílico, pois este pode prejudicar propriedades de aderência devido à presença de óleos plastificantes em sua composição. Dessa maneira, ensaios comparativos podem demonstrar qual amostra de adesivo apresenta melhores comportamentos sob condições de migração de óleos sintéticos. O método de teste utilizado para obtenção do valor de adesão ao dorso vinílico foi baseado 
na NBR 5057 (Norma Brasileira Registrada)/ ABNT (Associação Brasileira de Normas Técnicas).

\section{Amostragem}

Foram selecionados quinze corpos de prova de cada experimento com dimensão de $450 \mathrm{~mm} \times 19 \mathrm{~mm}$ cada. Seis deles foram utilizados para o teste de adesão ao dorso logo após o processo de acondicionamento durante $24 \mathrm{~h}$, descrito no item abaixo. Os outros nove foram colocados em estufa durante 7 dias a $65^{\circ} \mathrm{C}$ e, após esse periodo, foram acondicionados durante 24 horas e então submetidos ao ensaio.

\section{Aparelhagem}

A mesma utilizada para o ensaio de determinação de adesão ao aço (ver item 3.3.7.1).

\section{Corpos de prova}

Os corpos de prova foram retirados do filme de PVC coberto com adesivo (descrito no item 3.3.1) com o auxílio de uma lâmina metálica cortante. Então, os mesmos foram acondicionados durante $24 \mathrm{~h}$ à temperatura de $(23 \pm$ $2)^{\circ} \mathrm{C}$ e a uma umidade relativa de $(50 \pm 5) \%$ antes de serem testados. 


\section{Procedimento}

Cada corpo de prova foi colocado com o lado do adesivo sobre a superfície de uma placa de aço, sendo que aproximadamente $250 \mathrm{~mm}$ ficaram fora da placa. Então, o rolete metálico foi colocado sobre o corpo de prova em uma das extremidades da placa e passado quatro vezes (duas vezes em uma direção e duas vezes na outra) com velocidade constante, sem que nenhuma pressão manual fosse aplicada. Cada percurso de $200 \mathrm{~mm}$ levou de $10 \mathrm{~s}$ a $12 \mathrm{~s}$, tomando-se cuidado de manter o rolete centralizado sobre o corpo de prova. Em seguida, um outro corpo de prova foi colocado com o lado do adesivo sobre o dorso da primeira amostra aplicada na placa de aço, e também foi passado o rolete nas mesmas condições descritas acima, conforme Figura 52.

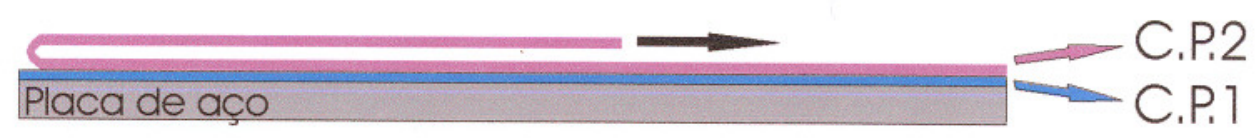

Figura 52 - llustração da montagem do corpo de prova para ensaio de adesão ao dorso

Essa montagem foi efetuada três vezes para cada experimento com o objetivo de determinar a adesão ao dorso sem exposição ao calor.

Em seguida, as amostras ficaram em repouso por $5 \mathrm{~min}$ a $(23 \pm 2)^{\circ} \mathrm{C}$ e a uma umidade relativa de $(50 \pm 5) \%$. Após o acondicionamento, o conjunto montado foi colocado na garra fixa da máquina de tração e a parte livre do corpo de prova foi fixada à garra móvel, a qual foi posta em movimento a uma 
velocidade de $(300 \pm 30) \mathrm{mm} / \mathrm{min}$. O equipamento efetuou leituras da força necessária para remover a amostra da placa de aço em intervalos consecutivos de $12.5 \mathrm{~mm}$. Todo o ensaio foi realizado a $(23 \pm 2)^{\circ} \mathrm{C}$ e a uma umidade relativa de $(50 \pm 5) \%$.

Para as amostras que foram submetidas ao calor, a montagem incluiu um terceiro corpo de prova sobre a amostra 2, conforme Figura 53.

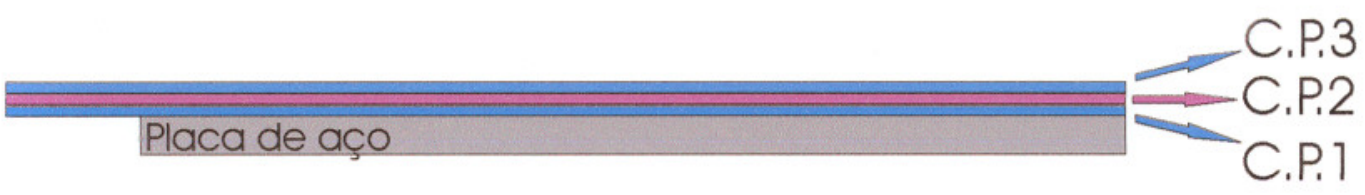

Figura 53 - llustração da montagem do ensaio para adesão ao dorso após exposição ao calor

O objetivo desta montagem foi simular uma migração acelerada do óleo plastificante, que compõe o filme vinílico flexível, em ambos os lados do corpo de prova 2, o qual foi testado a adesão ao dorso. Após exposição ao calor, as amostras ficaram em repouso por $5 \min$ a $(23 \pm 2)^{\circ} \mathrm{C}$ e a uma umidade relativa de $(50 \pm 5) \%$. Após o acondicionamento, o conjunto montado foi colocado na garra fixa da máquina de tração e a parte livre do corpo de prova foi fixada à garra móvel, a qual foi posta em movimento a uma velocidade de (300 \pm 30) $\mathrm{mm} / \mathrm{min}$. O equipamento efetuou leituras da força necessária para remover a amostra da placa de aço em intervalos consecutivos de $12,5 \mathrm{~mm}$. Todo o ensaio foi realizado a $(23 \pm 2)^{\circ} \mathrm{C}$ e a uma umidade relativa de $(50 \pm 5) \%$. 


\subsubsection{Fluência sob cisalhamento ("Shear-Creep")}

O objetivo deste ensaio foi medir a deformação ao longo do tempo apresentada pelo adesivo quando submetido a um esforço cisalhante constante. Com esses valores foi possível determinar qual das amostras preparadas em laboratório apresentou maior resistência mecânica ao cisalhamento, característica importante para especificar a aplicação final do adesivo.

\section{Amostragem}

Para esse ensaio foi utilizada uma amostra da aproximadamente $15 \mathrm{~g}$ de cada adesivo produzido em laboratório.

\section{Aparelhagem}

- Reômetro de placas paralelas 25mm (Advanced Rheometric Expansion System - ARES-2KSTD)

- Estufa a $100^{\circ} \mathrm{C}$

- Papel revestido com silicone

\section{Preparacão do corpo-de-prova}

Aproximadamente $15 \mathrm{~g}$ de adesivo foram espalhados sobre uma folha de papel com tratamento de silicone, e o conjunto, papel mais amostra, foi 
submetido a $100^{\circ} \mathrm{C}$ durante 20 minutos. Após resfriamento de 30 minutos a temperatura ambiente, a amostra - parte sólida que restou após a evaporação do solvente - foi retirada do papel e submetida ao teste de reometria.

\section{Método de teste}

Para a análise do comportamento da deformação sob cisalhamento dos adesivos foi utilizada a técnica de reometria com configuração tipo placas paralelas. Neste ensaio, a amostra é posicionada entre as placas e, em seguida, uma tensão $(\tau)$ pré-determinada é aplicada no eixo inferior, que é mantida durante toda a duração do ensaio. A deformação $(\varepsilon)$ apresentada pelo material é analisada por um dispositivo eletrônico instalado no eixo superior. A Figura 54 ilustra a construção do equipamento.
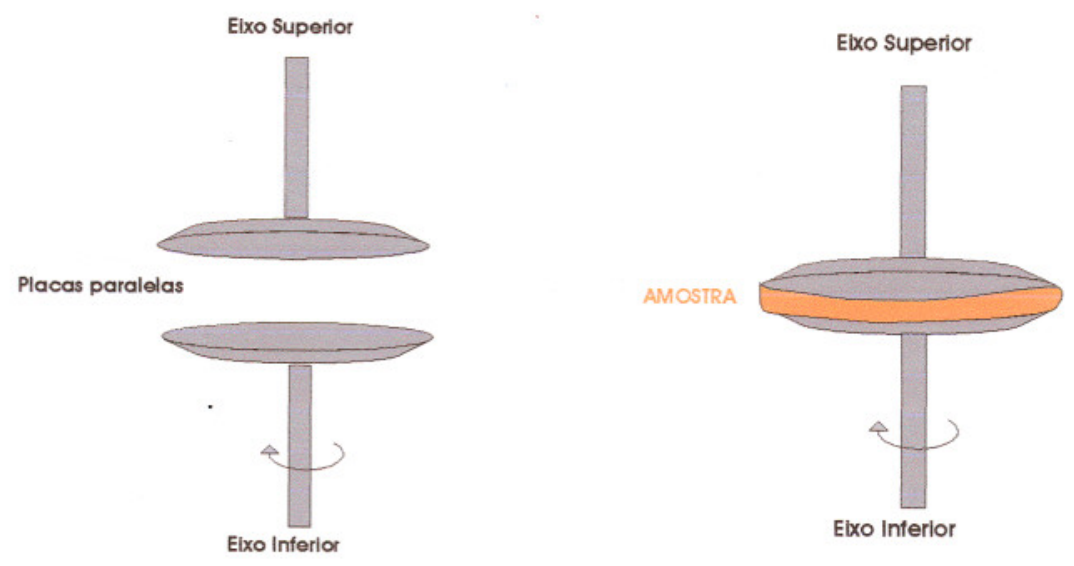

Figura 54 - llustração do reômetro de torque de placas paralelas

As informações de tempo, deformação e tensão são processadas pelo software do equipamento e compiladas em um gráfico, conforme Figura 55. 
A3X

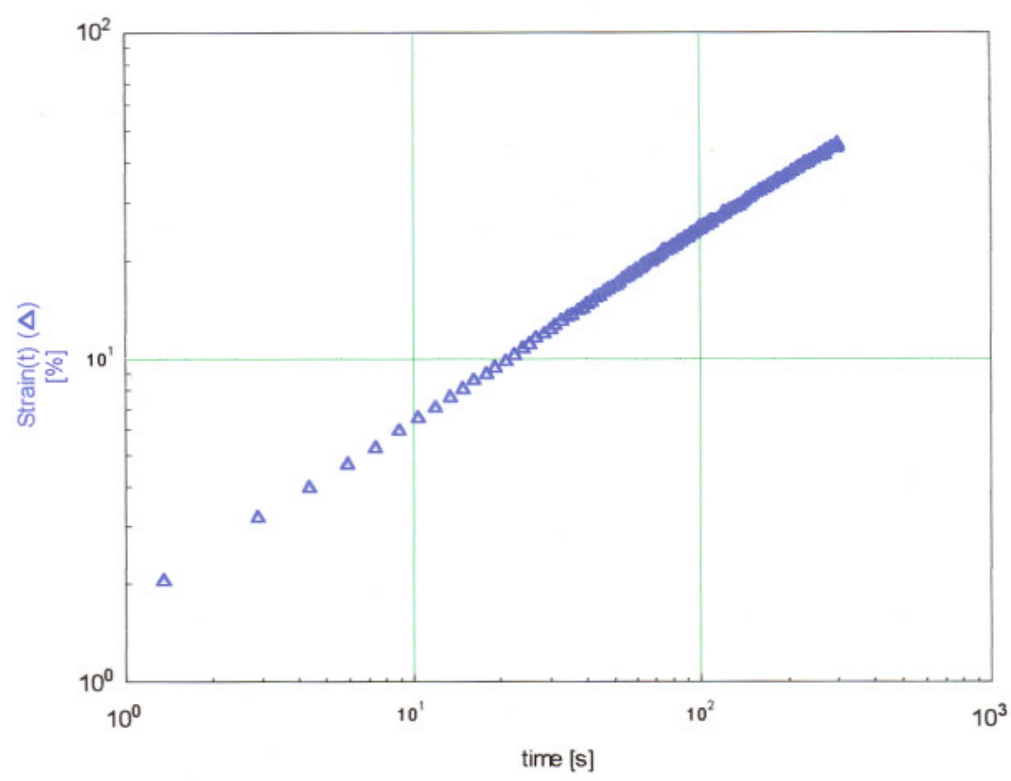

Figura 55 - Exemplo de uma curva de reometria shear-creep do tipo placas paralelas

As condições utilizadas para a realização dos ensaios foram:

- Tensão constante $(\tau)=2.000 \mathrm{dyn} / \mathrm{cm}^{2}$.

- Deformação $(\varepsilon)$ = variável (objetivo do ensaio)

- Temperatura da amostra $=25^{\circ} \mathrm{C}$

- Temperatura do ambiente $=25^{\circ} \mathrm{C}$

- Abertura entre as placas $=1,7 \mathrm{~mm}$

- Tempo de aplicação da tensão $=300$ s

\subsubsection{Cromatografia de permeação em Gel (GPC)}

As propriedades únicas dos polímeros são resultantes em primeiro lugar do peso molecular que possuem. A flexibilidade molecular, ligações de 
hidrogênio, cristalinidade, ligações cruzadas, etc, têm uma participação complementar nestas propriedades. A cromatografia de permeação em gel é uma das técnicas mais úteis e versáteis para entender e predizer o tamanho da molécula de um polímero. Através dela é possível determinar a massa molar média de polímeros e sua distribuição.

Esse ensaio consiste de uma separação em uma coluna completamente preenchida com partículas rígidas e porosas de "gel". Os poros dessas partículas são de tamanho estatisticamente compatível às das moléculas de polímeros que serão separadas. Neste tipo de cromatografia estão presentes duas fases: uma fase líquida estacionária e outra fase móvel. A primeira corresponde ao líquido dentro dos poros, e a fase móvel corresponde à parte fora dos poros. As moléculas de polímeros são separadas pelo seu tamanho, dependendo de sua habilidade em penetrar na fase estacionária. A medida que a amostra se move ao longo da coluna com a fase móvel, as moléculas maiores são quase que excluídas inteiramente da fase estacionária, enquanto as moléculas menores penetrarão na fase estacionária com mais facilidade. Quanto menor a molécula, mais volume de fase estacionária será acessível a ela e mais tempo ela permanecerá nesta fase. Dessa maneira, as moléculas menores sairão da coluna depois das moléculas maiores.

\section{Amostragem}

Para esse ensaio foi utilizada uma amostra da aproximadamente $25 \mathrm{mg}$ de cada adesivo produzido em laboratório. 


\section{Aparelhagem}

- Cromatógrafo Shimadzu Scientific Inc 2010A

- Solvente THF (do inglês - tetrahydrofuran)

- "Filtro seringa de teflon" - 0,25 mícron

\section{Preparacão do corpo-de-prova}

Uma amostra de cada adesivo foi preparada com a adição de $10,0 \mathrm{ml}$ de THF para cada $25 \mathrm{mg}$ de adesivo. Após 24 horas de dissolução, cada solução foi filtrada em um "filtro seringa" de 0,25 micron de teflon.

\section{Método de teste}

Em cada ensaio, 100 microlitros foram injetados em duas colunas (do tipo Jordi leito misto e 500A) do cromatógrafo Shimadzu Scientific Inc 2010A. Operando a uma temperatura de $35^{\circ} \mathrm{C}$, e usando THF como eluente, a um fluxo de 1,0ml/min, foi possível detectar mudanças na concentração através de um detector do tipo Wyatt Tecnology Inc. Uma calibração foi realizada previamente com poliestireno de dispersividade conhecida e com faixa de peso molecular de $8,24 E+5$ e acima de 580 . O cálculo final do peso molecular foi obtido através do software Polymer Labs Cirrus. 


\subsubsection{Espectroscopia no infravermelho com transformada de} Fourier (FTIR).

A espectroscopia infravermelha se baseia na medição do comprimento de onda e intensidade da absorção de luz infravermelha em uma amostra. Analisa os movimentos de rotação e de vibrações dos átomos das moléculas. O comprimento de onda dos feixes de absorção infravermelha é típico de ligações químicas, e a maior utilidade da espectroscopia infravermelha encontra-se na identificação de moléculas orgânicas e organometálicas.

O espectrofotômetro infravermelho (IR) consiste em um equipamento capaz de transmitir uma luz através de uma amostra e produzir um espectro com o traçado da quantidade de luz transmitida no eixo vertical e o comprimento de onda da radiação no eixo horizontal. Neste tipo de espectro, os picos de absorção se dirigem para baixo, pois o eixo vertical é a transmitância percentual da radiação através da amostra. A absorção da radiação diminui o valor de transmitância percentual.

Existem quatro tipos de instrumentos para medições de absorção infravermelha: espectrofotômetros dispersivos, instrumentos de transformadas de Fourier, fotômetros não dispersivos e fotômetros de refletância.

Neste estudo foi utilizada a técnica de espectroscopia no infravermelho com transformada de Fourier (FTIR), com o objetivo de verificar possíveis alterações na estrutura química das amostras de adesivos. 


\section{Amostragem}

Para esse ensaio foi utilizada uma amostra da aproximadamente $5 \mathrm{~g}$ de cada adesivo produzido em laboratório.

\section{Aparelhagem}

- Lâmina de vidro;

- Espátula.

- Espectrofotômetro FTIR BOMEM (Hartmann \& Braun - MB series)

- Cristal constituído por Seleneto de Zinco

\section{Preparação do corpo-de-prova}

Fez-se um filme (ou uma película) para cada amostra de adesivo com o auxílio de uma espátula e uma lâmina de vidro. Esse filme foi colocado em uma estufa por 10 min a $100^{\circ} \mathrm{C}$ para a evaporação do solvente e, então, a amostra foi retirada e submetida ao ensaio.

\section{Método de teste}

As amostras preparadas previamente foram colocadas no cristal do equipamento, espectrofotômetro FTIR BOMEM (Hartmann \& Braun - MB series), para que a leitura pudesse ser realizada. Todos os ensaios foram 
realizados à temperatura de $(23 \pm 2){ }^{\circ} \mathrm{C}$. Cada leitura foi repetida para comprovar o resultado obtido. 
Nesta seção serão mostrados os resultados de medidas de propriedades físicas, químicas, mecânicas e reológicas obtidos através das técnicas descritas no capítulo 3, com o objetivo de verificar as alterações ocorridas nas amostras preparadas em laboratório com modificações em suas fórmulas e condições de processamento.

\subsection{Viscosidade}

Na Tabela 08 se observa o resultado da viscosidade juntamente com a temperatura de cada amostra analisada.

Tabela 08 - Resultados da viscosidade Brookfield

\begin{tabular}{|c|c|c|c|c|c|c|}
\hline \multicolumn{8}{c|}{ VISCOSIDADE BROOKFIELD } \\
\hline Experimento & 1A & 2A & 3A & 1B & 2B & 3B \\
\hline Temperatura $\left({ }^{\circ} \mathrm{C}\right)$ & 24,2 & 24,1 & 24,3 & 24,4 & 24,3 & 24,2 \\
Viscosidade (CP) & 6420 & 6210 & 6420 & 6320 & 6190 & 6210 \\
\hline
\end{tabular}

A Figura 56 exibe os valores obtidos para a viscosidade versus temperatura. 
VISCOSIDADE BROOKFIELD X TEMPERATURA

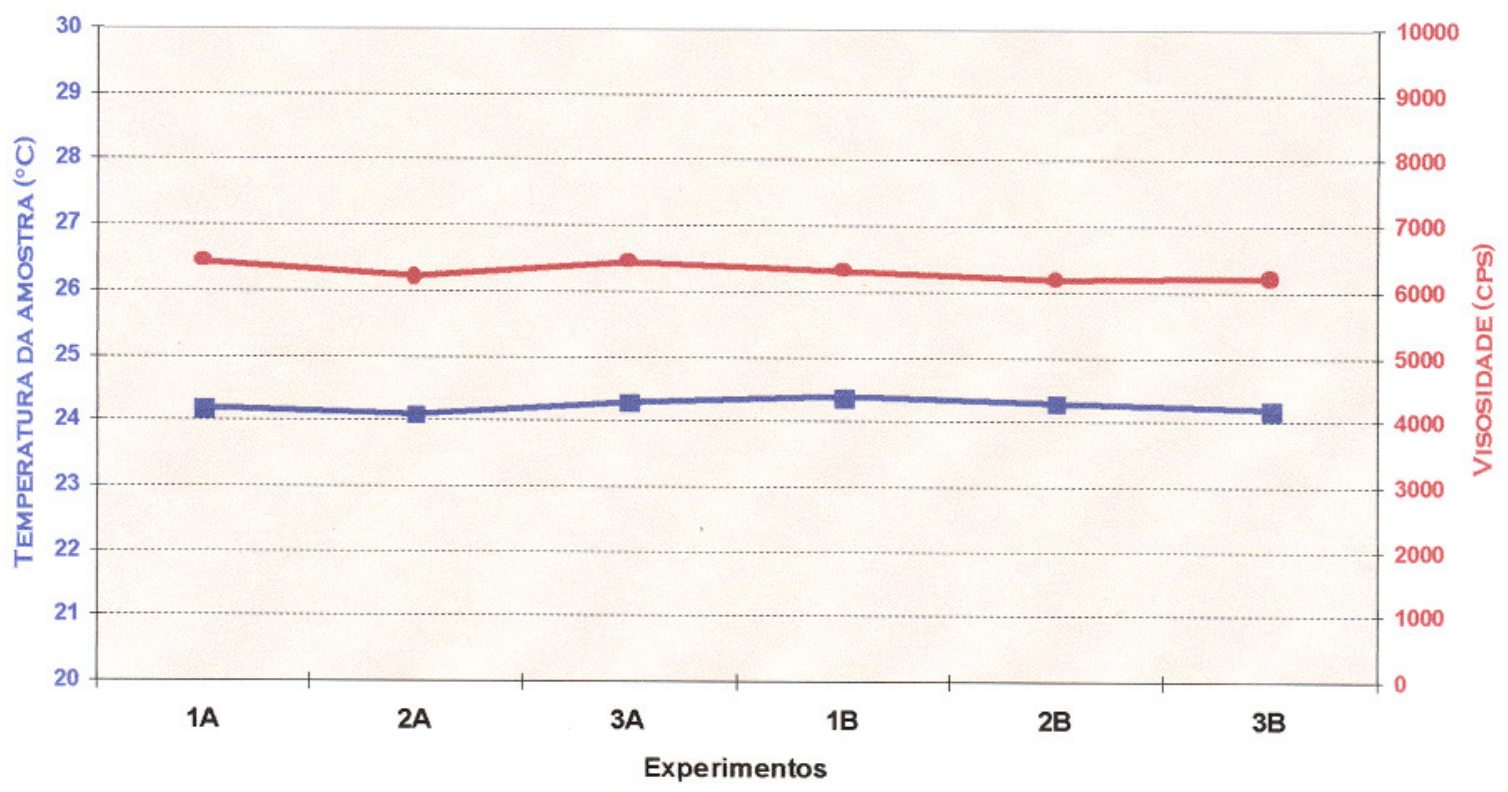

Figura 56 - Gráfico da viscosidade Brookfield

Percebe-se que o valor encontrado para a viscosidade de cada experimento é praticamente o mesmo, isto é, as amostras apresentam diferenças despreziveis, que podem ser conseqüência de pequenas alterações na temperatura e na execução do ensaio. Conforme mencionado no item (3.3.2), as viscosidades de todas as amostras foram ajustadas para que se pudesse mantê-la como uma propriedade de referência. Dessa maneira, outras variações físicas e reológicas podem ser investigadas.

\subsection{Percentual de materiais sólidos}

A Tabela 09 exibe os dois valores obtidos para o percentual de sólidos de cada experimento. 
Tabela 09 - Resultados da quantidade de materiais sólidos

\begin{tabular}{|c|c|c|c|c|c|c|}
\hline \multicolumn{7}{|c|}{ QUANTIDADE DE MATERIAIS SÓLIDOS } \\
\hline Experimento & 1A & 2A & 3A & 1B & 2B & 3B \\
\hline Quantidade de materiais & $38,2 \%$ & $39,5 \%$ & $40,9 \%$ & $41,3 \%$ & $45,0 \%$ & $45,2 \%$ \\
\hline sólidos [\%] & $38,4 \%$ & $39,6 \%$ & $41,7 \%$ & $42,1 \%$ & $44,7 \%$ & $44,8 \%$ \\
\hline MÉDIA [\%] & $38,3 \%$ & $39,5 \%$ & $41,3 \%$ & $41,7 \%$ & $44,9 \%$ & $45,0 \%$ \\
\hline
\end{tabular}

A figura 57 exibe os valores obtidos do percentual de sólidos.

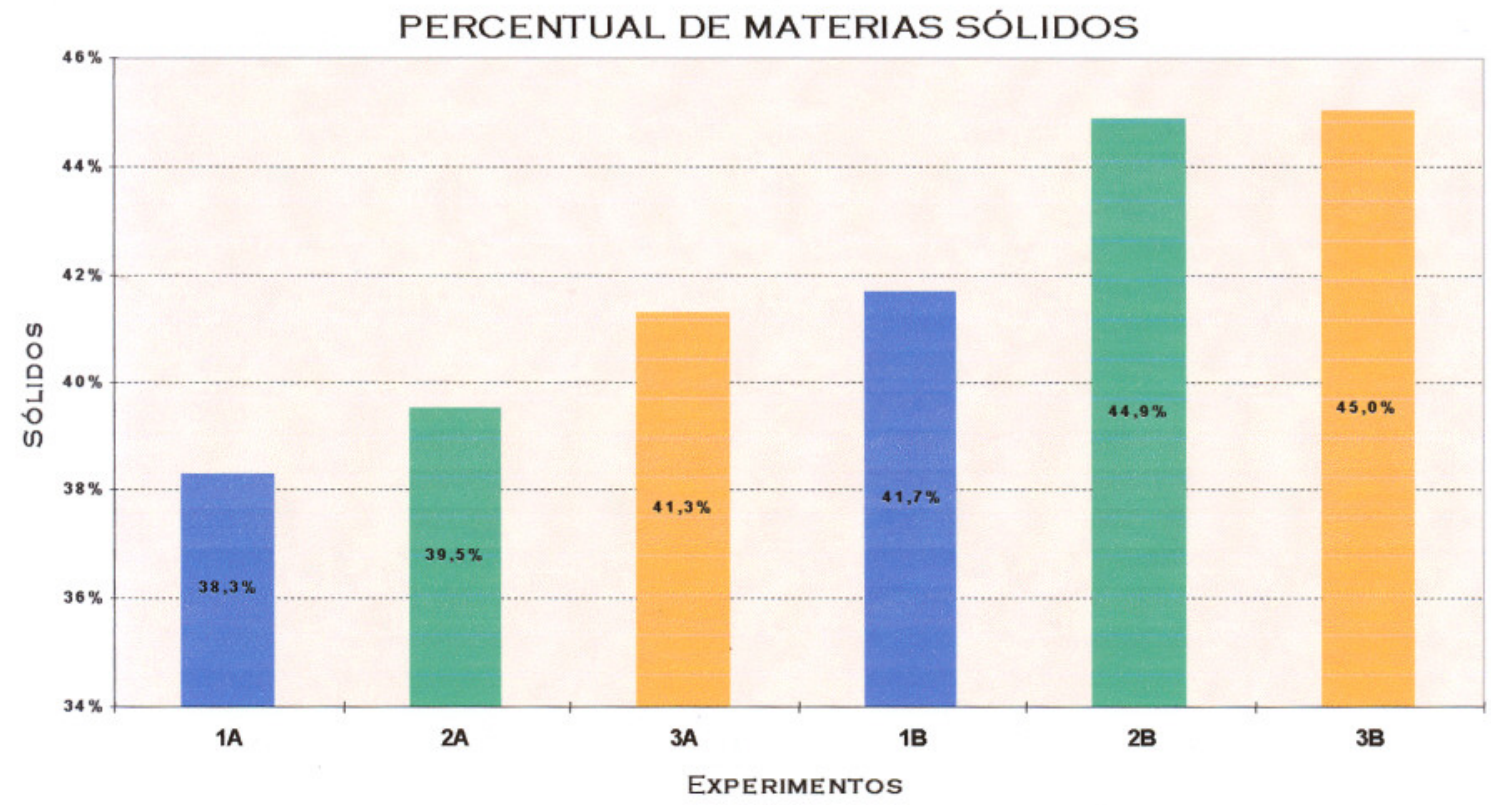

Figura 57 - Gráfico do percentual de sólidos

Os valores de percentual de sólidos contido nas amostras foram comparados com os resultados obtidos para a viscosidade, conforme Figura 58. 
VISCOSIDADE BROOKFIELD x SÓLIDOS

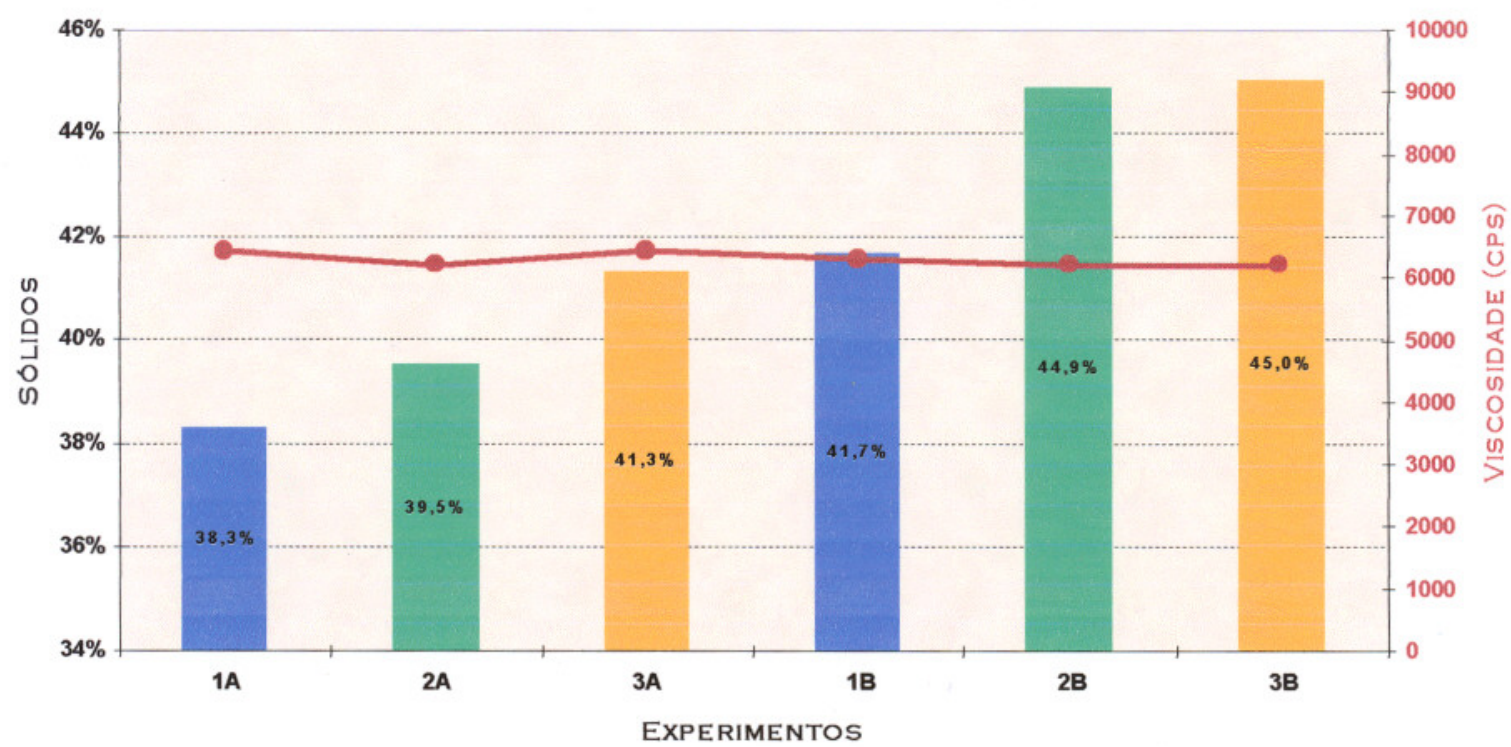

Figura 58 - Gráfico do percentual de sólidos versus a viscosidade Brookfield

Com base nos resultados, é fácil perceber que o percentual de materiais sólidos tem uma forte relação com o grau de ligação cruzada, isto é, os experimentos com alto nível de reação $(1 A, 2 A$ e $3 A)$, para uma mesma formulação e a uma mesma viscosidade, apresentaram uma menor quantidade de materiais sólidos. Logo, conclui-se que uma maior quantidade de reação (maior intensidade de ligações cruzadas) dificulta a solubilização, pois para atingir valores de viscosidade iguais aos experimentos de baixa reação foi necessária a adição de maiores quantidades de solvente, visto que um menor percentual de sólidos significa que a amostra tem maior quantidade de solvente. 


\subsection{Ancoragem do adesivo no dorso de PVC}

O software do equipamento utilizado para a realização do ensaio de ancoragem fez uma média dos valores obtidos para cada ensaio, resultando no valor médio de ancoragem, expresso em gf/ 12mm (essa unidade foi adotada pelo fato de a fita padrão ter largura de $12 \mathrm{~mm}$ ). A Tabela 10 exibe esses dados para os corpos de prova testados sem e com exposição ao calor, para cada experimento. Também exibe valores para a diferença em percentual dos valores de ancoragem, que foi calculada segundo a fórmula:

$$
\% Q A=(A S-A C) * 100 / A S
$$

Sendo:

QA - queda de ancoragem

AS - ancoragem sem estufa

AC - ancoragem após exposição ao calor

Tabela 10 - Resultados de ancoragem

\begin{tabular}{|c|c|c|c|c|c|c|}
\hline \multicolumn{7}{|c|}{ TESTES DE ANCORAGEM REALIZADOS COM FILME FLEXÍVEL DE PVC } \\
\hline EXPERIMENTOS & $1 \mathrm{~A}$ & 2A & 3A & 1B & 2B & 3B \\
\hline \multirow{3}{*}{$\begin{array}{l}\text { Ancoragem sem } \\
\text { Estufa }[\mathrm{gf} / 12 \mathrm{~mm}]\end{array}$} & 1200 & 1315 & 1260 & 1340 & 1410 & 1320 \\
\hline & 1310 & 1320 & 1190 & 1340 & 1420 & 1342 \\
\hline & 1270 & 1290 & 1250 & 1450 & 1530 & 1300 \\
\hline MÉDIA & 1260 & 1308 & 1233 & 1377 & 1453 & 1321 \\
\hline \multirow{3}{*}{$\begin{array}{l}\text { Ancoragem com } \\
\text { Estufa }[\mathrm{gf} / 12 \mathrm{~mm}]\end{array}$} & 700 & 1090 & 1150 & 1060 & 1230 & 1230 \\
\hline & 880 & 1100 & 980 & 980 & 1210 & 1210 \\
\hline & 820 & 1110 & 1020 & 1090 & 1200 & 1180 \\
\hline MÉDIA & 800 & 1100 & 1050 & 1043 & 1213 & 1207 \\
\hline \multicolumn{7}{|c|}{ QUEDA DO VALOR DE ANCORAGEM APÓS EXPOSIÇÃO AO CALOR } \\
\hline PERCENTUAL & $37 \%$ & $16 \%$ & $15 \%$ & $\mathbf{2 4 \%}$ & $17 \%$ & $\mathbf{9 \%}$ \\
\hline
\end{tabular}


A Figura 59 exibe os valores obtidos de ancoragem, para os corpos de prova testados sem e com exposição ao calor, para cada experimento.

\section{ANCORAGEM}

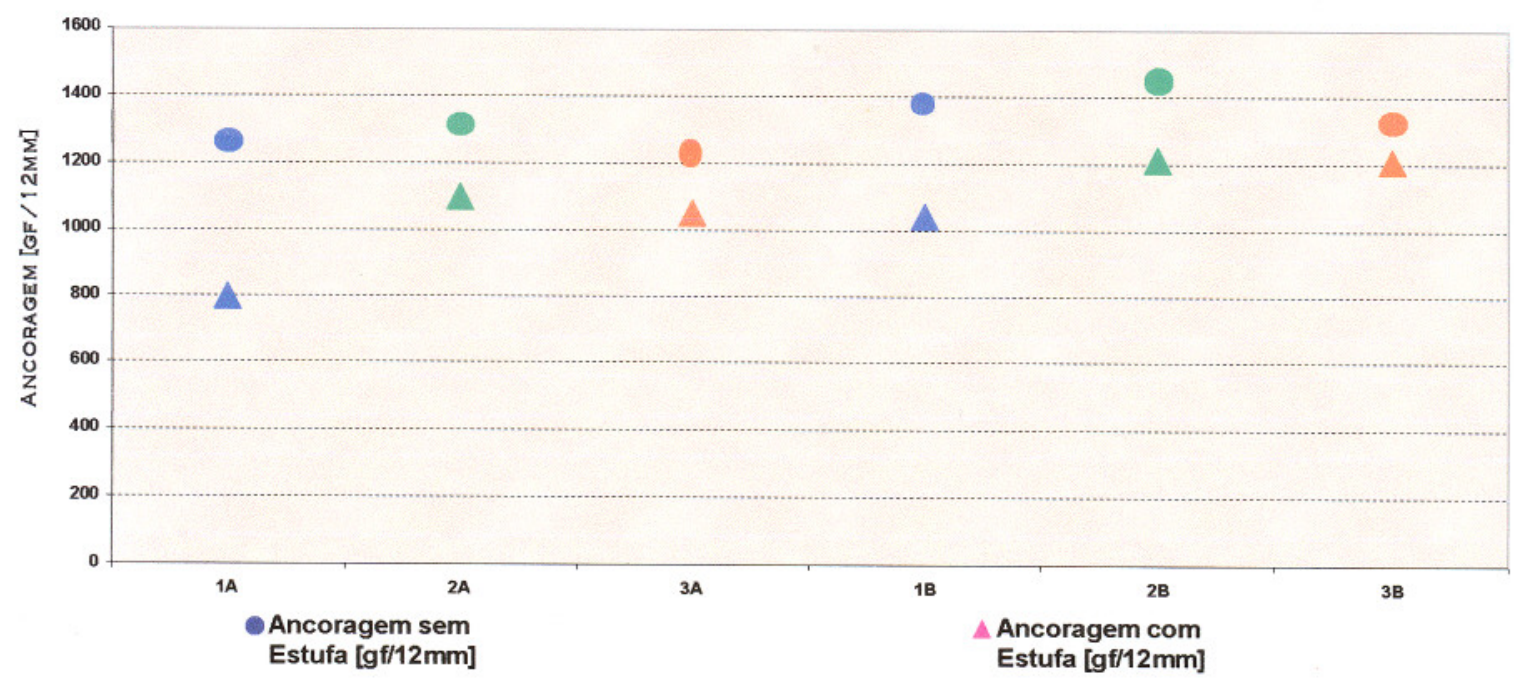

Figura 59 - Gráfico dos valores de ancoragem

A Figura 60 exibe os valores obtidos para a queda de ancoragem, isto é, a diferença entre antes e depois à exposição ao calor, para cada experimento.

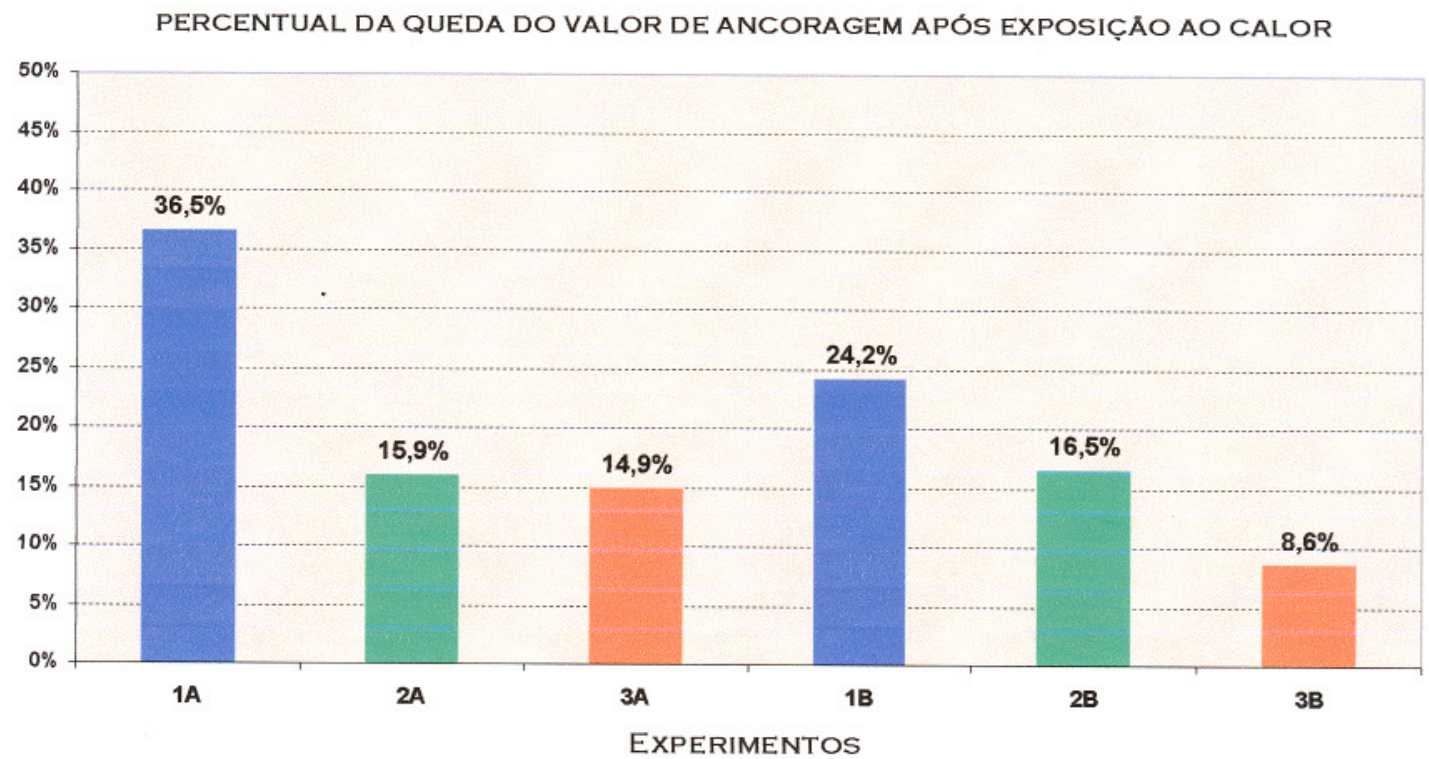

Figura 60 - Gráfico dos valores de ancoragem após exposição ao calor 
Conforme os resultados mostrados na figura 59 , a exposição ao calor causa uma queda no valor de ancoragem, isto ocorre devido à migração dos óleos plastificantes contidos no filme de PVC. A Figura 60 indica que as formulações dois e três apresentaram uma menor queda do valor de ancoragem após exposição ao calor, quando comparadas com a fórmula um, pois a alta quantidade de ligações cruzadas, devido ao tempo de reação prolongado, dificulta a solubilidade do plastificante no adesivo.

\subsection{Resistência ao cisalhamento}

A Tabela 11 exibe os valores obtidos de resistência ao cisalhamento, para as duas amostras ensaiadas de cada experimento e a média dos resultados.

Tabela 11 - Resultados da resistência ao cisalhamento

\begin{tabular}{l}
\hline RESISTÉNCIA AO CISALHAMENTO \\
\begin{tabular}{|c|c|c|c|c|c|c|}
\hline Experimento & $1 \mathrm{~A}$ & $2 \mathrm{~A}$ & $3 \mathrm{~A}$ & $1 \mathrm{~B}$ & $2 \mathrm{~B}$ & $3 \mathrm{~B}$ \\
\hline Tempo para & 7 & 11 & 8 & 3 & 5 & 4 \\
romper [min] & 7 & 12 & 9 & 2 & 4 & 3 \\
\hline MÉDIA [min] & $\mathbf{7 , 0}$ & 11,5 & $\mathbf{8 , 5}$ & $\mathbf{2 , 5}$ & $\mathbf{4 , 5}$ & 3,5 \\
\hline
\end{tabular}
\end{tabular}

A Figura 61 exibe os valores obtidos para a resistência ao cisalhamento, isto é, a diferença entre os tempos para a queda do corpo de prova inferior. 


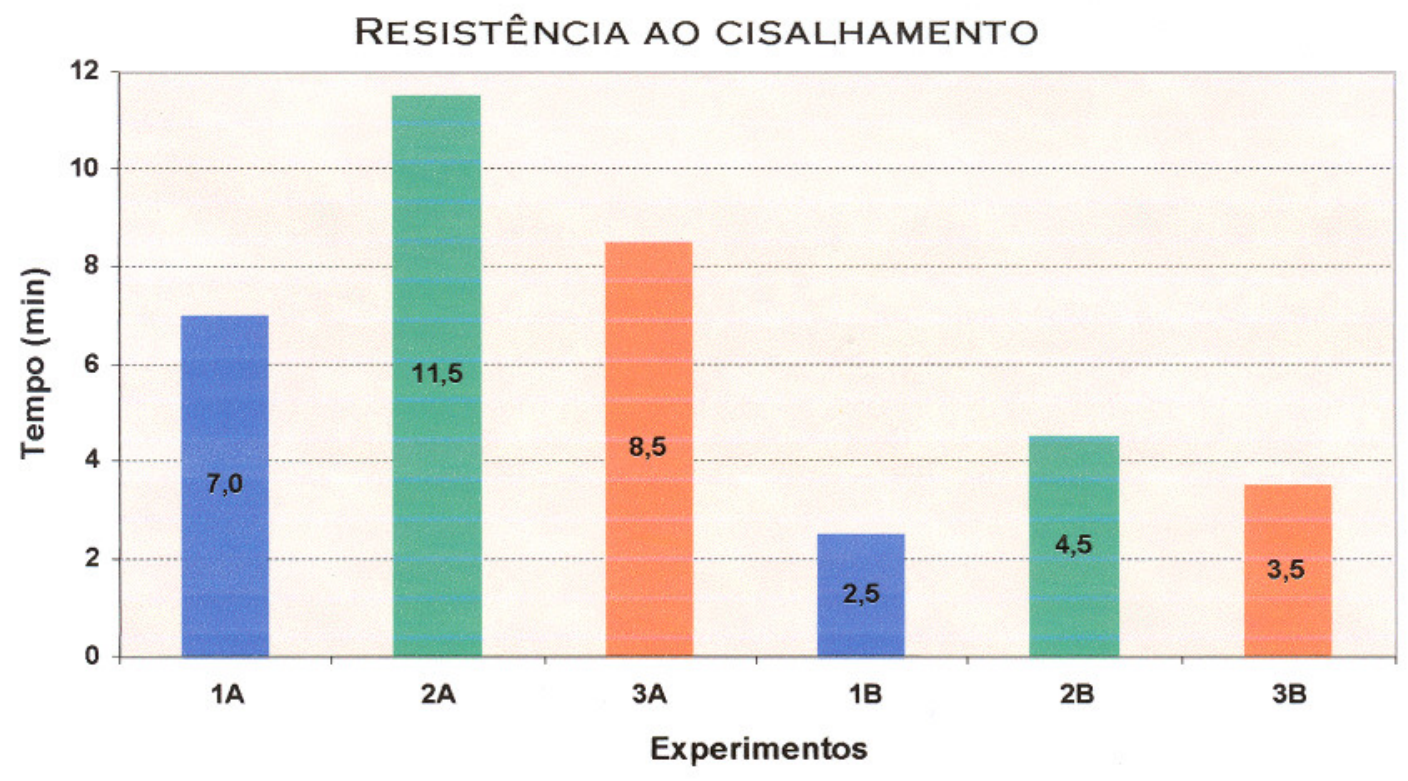

Figura 61 - Gráfico da resistência ao cisalhamento

Esses dados indicam que as amostras com alto nível de reação (1A, $2 \mathrm{~A}$ e $3 \mathrm{~A}$ ) apresentaram um aumento expressivo no tempo de queda do corpo de prova ensaiado, em relação às amostras com baixo nível de reação. Isto prova que uma maior quantidade de ligações cruzadas favorece a resistência ao cisalhamento. Também é perceptível que a fórmula número dois apresentou melhores resultados, para o mesmo nível de reação. $A$ amostra $2 A$ apresentou um aumento de $64 \%$ da resistência ao cisalhamento (através desse procedimento) em relação à referência $1 \mathrm{~A}$, enquanto que a amostra $3 \mathrm{~A}$ apresentou um aumento de apenas $21 \%$, ambas para um alto nível de reação.

\subsection{Grau de ligações cruzadas}

$\mathrm{Na}$ Tabela 12 estão os resultados das pesagens realizadas para cada um dos três corpos de prova testados para os seis adesivos experimentais. 
Tabela 12 - Resultados do ensaio de grau de ligações cruzadas

\begin{tabular}{|c|c|c|c|c|c|c|c|}
\hline & \multicolumn{7}{|c|}{ PERCENTUAL DE MATERIAL NÃO SOLÚYEL EM TOLUOL } \\
\hline & EXPERIMENTOS & $1 A$ & 2A & 3A & $1 B$ & 2B & 3B \\
\hline \multirow{8}{*}{ 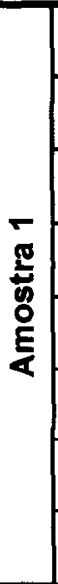 } & $\begin{array}{l}\text { Peso da amostra } \\
50 \mathrm{~mm} \times 50 \mathrm{~mm}(\mathrm{~g})\end{array}$ & 0,162 & 0,159 & 0,16 & 0,166 & 0,159 & 0,148 \\
\hline & $\begin{array}{l}\text { Peso do filme de Poliéster } \\
50 \mathrm{~mm} \times 50 \mathrm{~mm}(\mathrm{~g})\end{array}$ & 0,071 & 0,077 & 0,075 & 0,068 & 0,073 & 0,073 \\
\hline & \begin{tabular}{|c|} 
Camada resvestida de adesivo \\
(g)
\end{tabular} & 0,091 & 0,082 & 0,085 & 0,098 & 0,086 & 0,075 \\
\hline & Peso da cesta mais amostra $(\mathrm{g})$ & 2,238 & 3,17 & 3,033 & 3,49 & 3,13 & 2,07 \\
\hline & $\begin{array}{c}\text { Peso da cesta mais amostra } \\
\text { aposs } 24 \mathrm{~h}(\mathrm{~g})\end{array}$ & 2,152 & 3,096 & 2,955 & 3,395 & 3,049 & 1,999 \\
\hline & Peso da cesta (g) & 2,076 & 3,011 & 2,873 & 3,324 & 2,971 & 1,922 \\
\hline & Resíduo de adesivo (g) & 0,005 & 0,008 & 0,007 & 0,003 & 0,005 & 0,004 \\
\hline & $\begin{array}{c}\text { Percentual de amostra insolúvel } \\
\text { em Toluol }\end{array}$ & $5,5 \%$ & $9,8 \%$ & $8,2 \%$ & $3,1 \%$ & $5,8 \%$ & $5,3 \%$ \\
\hline \multirow{8}{*}{ 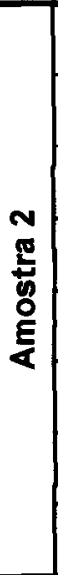 } & \begin{tabular}{|c|} 
Peso da amostra \\
$50 \mathrm{~mm} \times 50 \mathrm{~mm}(\mathrm{~g})$
\end{tabular} & 0,164 & 0,161 & 0,161 & 0,158 & 0,161 & 0,151 \\
\hline & $\begin{array}{l}\text { Peso do filme de Poliéster } \\
50 \mathrm{~mm} \times 50 \mathrm{~mm}(\mathrm{~g})\end{array}$ & 0,071 & 0,077 & 0,075 & 0,068 & 0,073 & 0,073 \\
\hline & $\begin{array}{c}\text { Camada resvestida de adesivo } \\
\text { (g) }\end{array}$ & 0,093 & 0,084 & 0,086 & 0,09 & 0,088 & 0,078 \\
\hline & Peso da cesta mais amostra $(g)$ & 3,614 & 2,1 & 3,702 & 2,944 & 3,085 & 2,812 \\
\hline & $\begin{array}{c}\text { Peso da cesta mais amostra } \\
\text { apos } 24 \mathrm{~h}(\mathrm{~g})\end{array}$ & 3,526 & 2,023 & 3,624 & 2,857 & 3,003 & 2,738 \\
\hline & Peso da cesta (g) & 3,45 & 1,939 & 3,541 & 2,786 & 2,924 & 2,661 \\
\hline & Resíduo de adesivo (g) & 0,005 & 0,007 & 0,008 & 0,003 & 0,006 & 0,004 \\
\hline & $\begin{array}{c}\text { Percentual de amostra insolúvet } \\
\text { em Toluol }\end{array}$ & $\mathbf{5 , 4 \%}$ & $8,3 \%$ & $9,3 \%$ & $3,3 \%$ & $6,8 \%$ & $5,1 \%$ \\
\hline \multirow{10}{*}{ 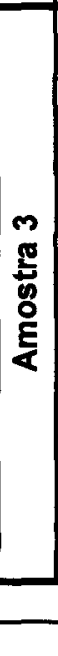 } & $\begin{array}{l}\text { Peso da amostra } \\
50 \mathrm{~mm} \times 50 \mathrm{~mm}(\mathrm{~g})\end{array}$ & 0,165 & 0,16 & 0,162 & 0,159 & 0,164 & 0,148 \\
\hline & $\begin{array}{l}\text { Peso do filme de Poliéster } \\
50 \mathrm{~mm} \times 50 \mathrm{~mm}(\mathrm{~g})\end{array}$ & 0,071 & 0,077 & 0,075 & 0,068 & 0,073 & 0,073 \\
\hline & \begin{tabular}{|c|} 
Camada resvestida de adesivo \\
$(\mathrm{g})$
\end{tabular} & 0,094 & 0,083 & 0,087 & 0,091 & 0,091 & 0,075 \\
\hline & Peso da cesta mais amostra (g) & 3,017 & 2,168 & 2,184 & 2,874 & 3,069 & 2,912 \\
\hline & $\begin{array}{c}\text { Peso da cesta mais amostra } \\
\text { após 24h (g) }\end{array}$ & 2,928 & 2,092 & 2,104 & 2,786 & 2,983 & 2,841 \\
\hline & Peso da cesta (g) & 2,852 & 2,008 & 2,022 & 2,715 & 2,905 & 2,764 \\
\hline & Resíduo de adesivo (g) & 0,005 & 0,007 & 0,007 & 0,003 & 0,005 & 0,004 \\
\hline & $\begin{array}{c}\text { Percentual de amostra insolúvel } \\
\text { em Toluol }\end{array}$ & $5,3 \%$ & $8,4 \%$ & $8,0 \%$ & $3,3 \%$ & $5,5 \%$ & $5,3 \%$ \\
\hline & MÉDIA GERAL & $5,4 \%$ & $8,8 \%$ & $8,5 \%$ & $3,2 \%$ & $6,0 \%$ & $\mathbf{5 , 3} \%$ \\
\hline & DESVIO PADRÁO & $0,1 \%$ & $0,8 \%$ & $0,7 \%$ & $0,1 \%$ & $0,7 \%$ & $0,1 \%$ \\
\hline
\end{tabular}


Para a obtenção do peso da camada revestida de adesivo utilizou-se a seguinte fórmula:

Camada revestida $=$ peso da amostra - peso do filme de Poliéster

Para a obtenção do peso da cesta utilizou-se a seguinte fórmula:

$$
\text { Peso da cesta }=\text { peso da cesta mais amostra }- \text { peso da amostra }
$$

Para a obtenção do resíduo de adesivo utilizou-se a seguinte fórmula:

Resíduo de adesivo $=$ peso do conjunto após $24-$ (peso cesta + peso do filme de Poliéster)

Para a obtenção do percentual da amostra insolúvel utilizou-se a seguinte fórmula:

Percentual da amostra insolúvel $=($ Resíduo de adesivo $/$ Camada revestida $)$ *100

A Figura 62 exibe o grau de ligação cruzada obtido para cada amostra. 


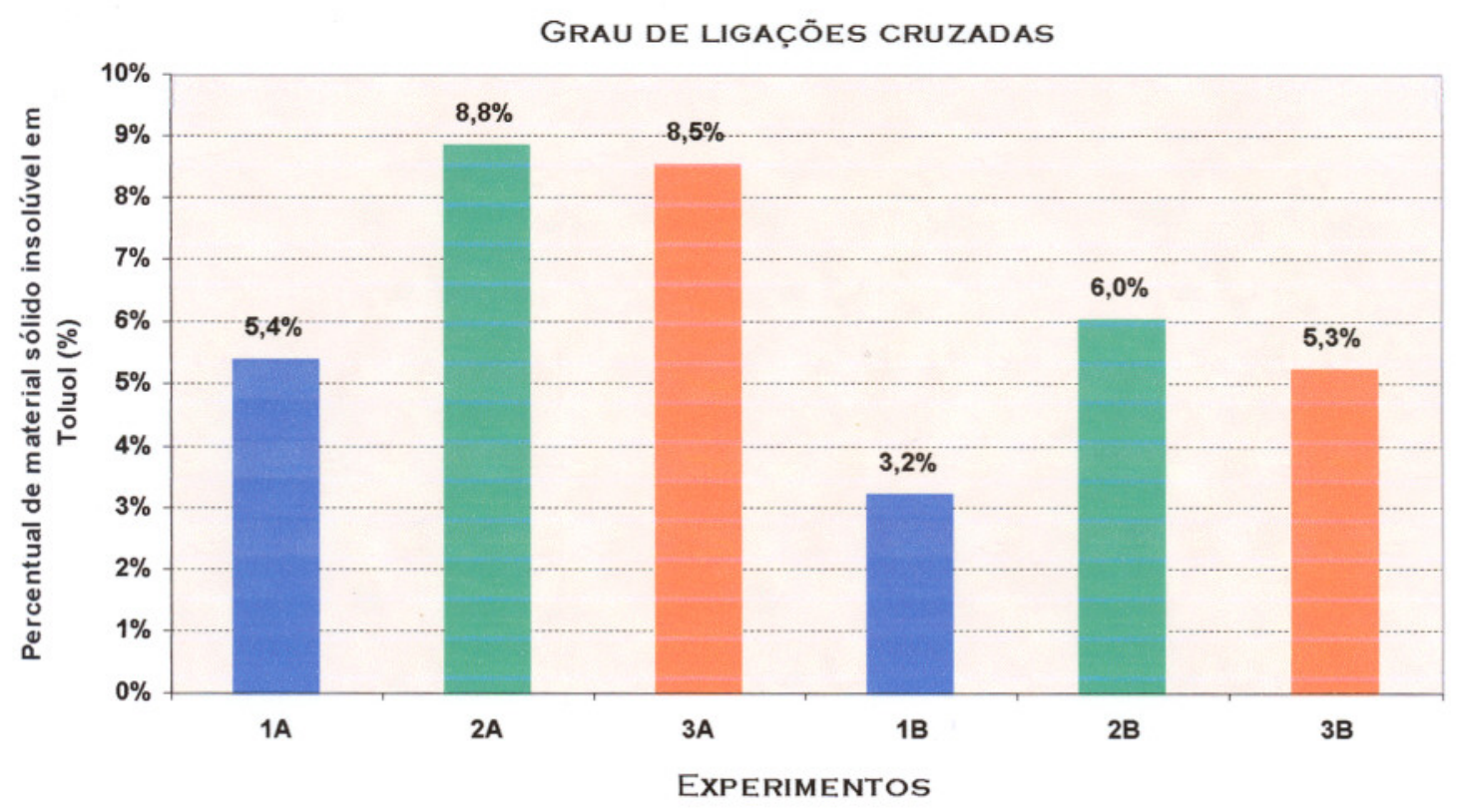

Figura 62 - Gráfico do grau de ligações cruzadas

Os resultados aqui apresentados provam que um maior nível de reação (amostras 1A, 2A e 3A) confere um maior grau de ligações cruzadas, como já mencionado na literatura ${ }^{(5)}$. Também se conclui que as fórmulas dois e três têm um maior grau de ligações cruzadas quando comparadas com a fórmula um, para um mesmo nível de reação.

\subsection{Adesão}

\subsubsection{Adesão em superfície metálica}

O software do equipamento utilizado para a realização do ensaio de adesão em superfície metálica fez uma média dos valores obtidos para cada ensaio, resultando no valor médio de adesão ao aço, expresso em gf/19mm (unidade definida como padrão na norma brasileira para fitas adesivas de PVC 
- NBR 5057). A Tabela 13 exibe esses dados para os corpos de prova testados sem e com exposição ao calor, para cada experimento.

Tabela 13 - Valores de adesão em superficie metálica

\begin{tabular}{ccccccc} 
TESTES DE ADESÃO EM SUPERFÍCIE METÁLICA REALIZADOS COM FILME FLEXÍVEL DE PVC \\
EXPERIMENTOS & $\mathbf{1 A}$ & $\mathbf{2 A}$ & $\mathbf{3 A}$ & $\mathbf{1 B}$ & $\mathbf{2 B}$ & 3B \\
\hline Adesão ao Aço & 1188 & 1728 & 1728 & 1086 & 2054 & 1648 \\
sem Estufa & 1304 & 1991 & 1821 & 1421 & 1771 & 1917 \\
[gf/19mm] & 1252 & 1709 & 1382 & 1276 & 1713 & 1581 \\
MÉDIA & $\mathbf{1 2 4 8}$ & $\mathbf{1 8 0 9}$ & $\mathbf{1 6 4 3}$ & $\mathbf{1 2 6 1}$ & $\mathbf{1 8 4 6}$ & $\mathbf{1 7 1 5}$ \\
Adesão ao Aço & 815 & 1115 & 1322 & 597 & 1098 & 1051 \\
com Estufa & 895 & 1214 & 1066 & 963 & 1346 & 1227 \\
[gf/19mm] & 1045 & 1175 & 1105 & 1041 & 1247 & 1307 \\
MÉDIA & $\mathbf{9 1 9}$ & $\mathbf{1 1 6 8}$ & $\mathbf{1 1 6 4}$ & $\mathbf{8 6 7}$ & $\mathbf{1 2 3 0}$ & $\mathbf{1 1 9 5}$ \\
\hline
\end{tabular}

A Figura 63 exibe os valores obtidos de adesão em superfície metálica, para os corpos de prova testados sem e com exposição ao calor, para cada experimento.

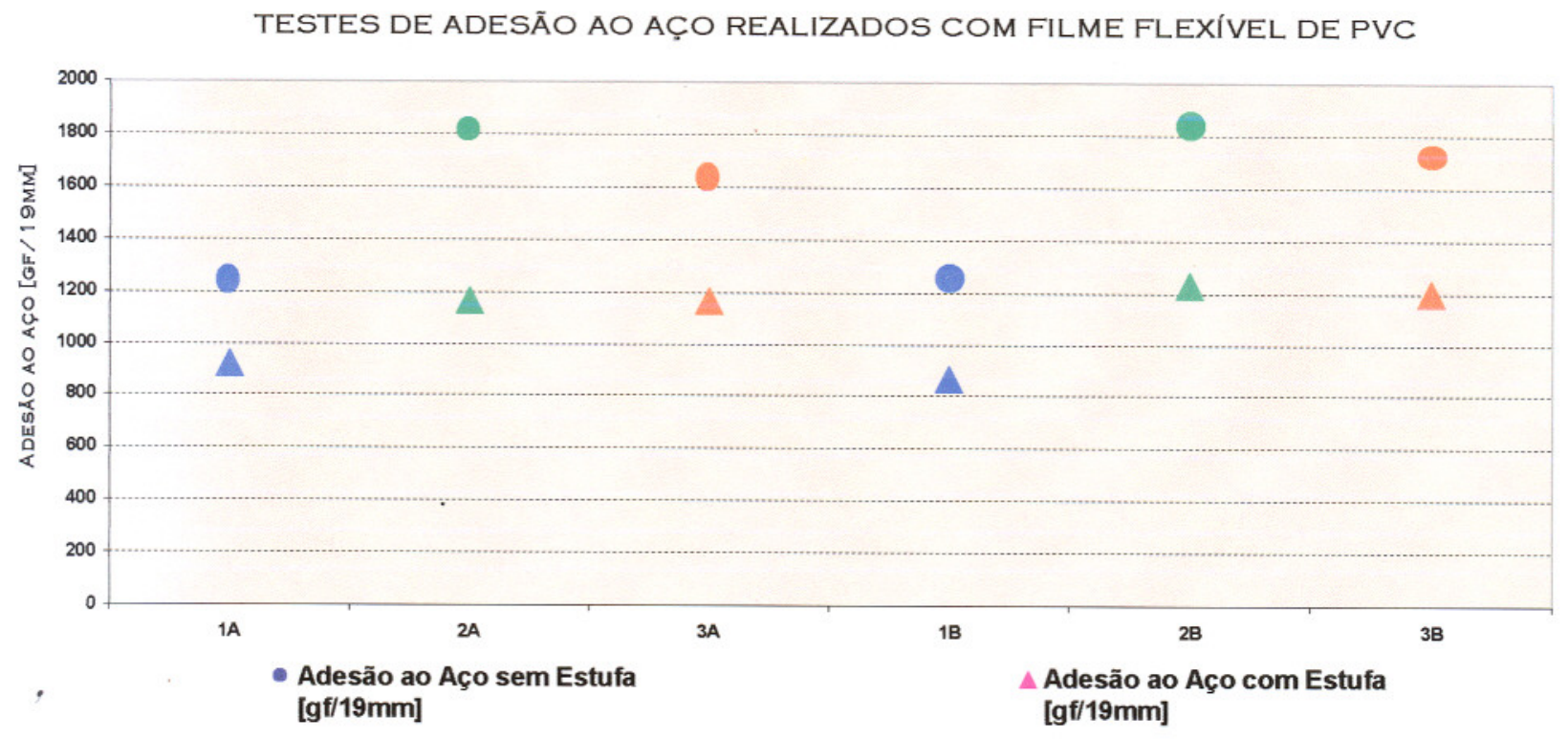

Figura 63 - Gráfico dos valores de adesão em superfície metálica

Os resultados indicam que a exposição ao calor causa uma queda nos valores de adesão em superfície metálica. Esse fato ocorre devido à presença 
de óleos plastificantes no substrato de PVC, os quais migram para a superfície durante a ação do calor, provocando uma interferência no fenômeno de adesão. Também é possível dizer que o alto nível de reação (amostras 1A, $2 \mathrm{~A}$ e 3A) causa pequenas diminuições nos valores de adesão em superfície metálica, quando comparado com a mesma fórmula. As formulações dois e três apresentaram maiores valores de adesão ao aço, quando comparadas com a fórmula um.

\subsubsection{Adesão em substrato vinílico}

O software do equipamento utilizado para a realização do ensaio de adesão em substrato vinílico fez uma média dos valores obtidos para cada ensaio, resultando no valor médio de adesão ao dorso, expresso em gf/19mm. A Tabela 14 exibe esses dados para os corpos de prova testados sem e com exposição ao calor, para cada experimento.

Tabela 14 - Valores de adesão em substrato vinílico

\begin{tabular}{ccccccc}
\hline \multicolumn{2}{c}{ TESTES DE ADESÃO EM } & SUBSTRATO VINÍlICO REALIZADOS COM FILME FLEXÍVEL DE PVC \\
EXPERIMENTOS & $\mathbf{1 A}$ & $\mathbf{2 A}$ & $\mathbf{3 A}$ & $\mathbf{1 B}$ & 2B & 3B \\
\hline Adesão ao Dorso & 1331 & 1404 & 1056 & 799 & 1719 & 1279 \\
sem Estufa & 1009 & 1376 & 1129 & 1101 & 1391 & 1165 \\
[gf/19mm] & $95 \dot{3}$ & 1436 & 1094 & 1013 & 992 & 1125 \\
MÉDIA & $\mathbf{1 0 9 7}$ & $\mathbf{1 4 0 5}$ & $\mathbf{1 0 9 3}$ & $\mathbf{9 7 1}$ & $\mathbf{1 3 6 7}$ & $\mathbf{1 1 9 0}$ \\
Adesão ao Dorso & 714 & 1211 & 1197 & 899 & 1137 & 1185 \\
com Estufa & 930 & 1114 & 1025 & 908 & $* 958$ & 1125 \\
[gf/19mm] & 910 & $\mathbf{9 7 4}$ & 1019 & 934 & *1147 & 929 \\
MÉDIA & $\mathbf{8 5 1}$ & $\mathbf{1 1 0 0}$ & $\mathbf{1 0 8 1}$ & $\mathbf{9 1 4}$ & $\mathbf{1 0 8 1}$ & $\mathbf{1 0 8 0}$ \\
\hline
\end{tabular}

A Figura 64 exibe os resultados obtidos de adesão em substrato vinílico para os corpos de prova testados sem e com exposição ao calor, para cada experimento: 
TESTES DE ADESĀO AO DORSO REALIZADOS COM FILME FLEXÍVEL DE PVC

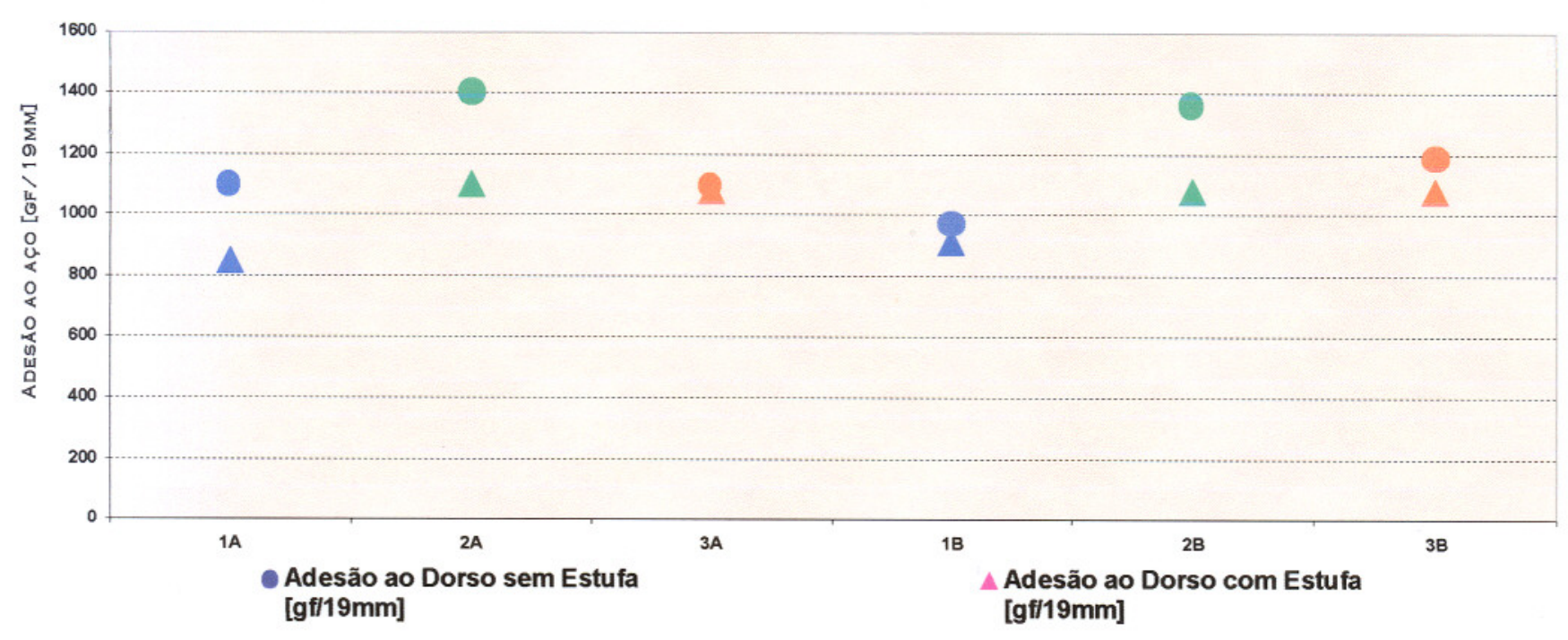

Figura 64 - Gráfico dos valores de adesão ao dorso

Pode-se observar que a exposição ao calor causa uma queda nos valores de adesão em substrato vinílico, analogamente à adesão a superfície metálica. Esse fato ocorre devido à presença de óleos plastificantes no substrato de PVC, os quais migram para a superfície durante a ação do calor. O fato de ter mantido o corpo de prova testado entre duas outras amostras, conforme descrito no item 3.3.7.2, favoreceu a migração dos plastificantes. Também é possível dizer que 0 alto nível de reação (para as amostras $1 \mathrm{~A}$ e 2A) causa um aumento nos valores de adesão em substrato de PVC, pois a formação de uma rede de ligações cruzadas dificulta a entrada de óleos plastificantes, evitando a queda do valor de adesão. Entretanto, esse fato não é evidenciado nas amostras provenientes da formula três. Os adesivos produzidos a partir da formulação dois apresentaram melhores resultados de adesão ao dorso, quando comparados com as outras composições, para uma mesma condição de processamento. Porém, a condição de baixo nível de 
reação (2B) apresentou deficiência de coesão para as amostras expostas ao calor, pois parte do adesivo do corpo de prova transferiu, isto é, sofreu remoção visualmente identificada, do substrato para o dorso.

\subsubsection{Discussão dos resultados de adesão}

O comportamento de aderência apresentada para cada amostra analisada é resultado de um ou mais mecanismos que ocorrem entre a superfície aplicada (metálica e vinílica) e o adesivo. Pode-se dizer que o mecanismo de intertravamento mecânico ocorre tanto para adesão ao aço quanto para a superfície vinílica, pois há rugosidade microscópica em ambas as superficies.

Parte da adesão apresentada pela amostra quando colocada em contato com a superfície metálica é explicada pela teoria da eletrostática, que é atribuída à transferência de elétrons através da interface, criando cargas positivas $\left(\delta^{+}\right)$e negativas $\left(\delta^{-}\right)$, quando o polímero entra em contato com o metal. Elétrons são transferidos do metal para o polímero, criando uma dupla camada de cargas. Essa força eletrostática gerada entre as cargas positivas e negativas auxilia a evitar a separação das partes ligantes (substrato e adesivo).

Adesão à superfície vinílica pode ser parcialmente explicada pelo mecanismo de difusão, que atribui o efeito da união de materiais poliméricos à interpenetração de cadeias químicas cruzando a interface. Esse conceito só é válido porque tanto o adesivo quanto o substrato são polímeros (adesivo a base de borracha e PVC com 45 pcr de plastificação) e ambos apresentam $\mathrm{Tg}$ abaixo da temperatura ambiente ${ }^{(10,11)}$. 
Segundo a teoria da adsorção (item 2.8), considerada o princípio mais importante para o fenômeno de adesão dos PSA`s, é fundamental um contato íntimo para que seja possível a formação de ligações de Van der Waals ou interação ácido-base, ou ainda as duas concomitantes. Para tal, é essencial que $\mathrm{o}$ adesivo apresente uma boa molhabilidade. No principio deste estudo acreditava-se que o aumento do peso molecular e a maior polidispersividade (item 4.8) apresentada pelas fórmulas submetidas a alto nível de reação (A) causaria uma diminuição no poder de adesão, pois o aumento do tamanho das cadeias poliméricas e o maior número de ramificações reduz o poder de molhabilidade. Esse efeito de decréscimo no poder de adesão foi identificado, porém mínimo, pois as alterações ocorridas na distribuição e PM foram muito pequenas. Em um trabalho futuro, pode-se avaliar essa redução no poder de adesão para materiais com grandes diferenças de distribuição de peso molecular.

O mecanismo de adesão por adsorção química, que explica o fenômeno de aderência devido à existência de ligações químicas primárias entre o adesivo e a superfície, não é observado nos adesivos sensíveis à pressão analisados neste trabalho. Pois nenhuma das superfícies estudadas (metálica e vinílica) é funcionalizada para poder reagir quimicamente com o adesivo. Entretanto, quando há a adsorção química, este é o mecanismo predominante.

\subsection{Fluência sob cisalhamento ("Shear-Creep")}

Para cada ensaio de fluência sob cisalhamento realizado foi obtida uma curva que relaciona o comportamento da deformação (em percentual) em 
função do tempo (em segundos) para uma tensão constante $(\tau)=2.000 \mathrm{dyn} /$ $\mathrm{cm}^{2}$ aplicada no eixo vertical das placas paralelas. Essa curva é típica de materiais elastoméricos; apresenta grandes deformações no início do ensaio e depois tende a estabilizar para uma deformação máxima, pois ocorre um rearranjo das cadeias poliméricas (quando o material está abaixo da Tg). Neste estudo o ensaio foi interrompido após 300 segundos, pois se buscou valor comparativo entre as amostras. Todos os resultados obtidos, dos seis experimentos realizados, foram colocados na Figura 65.

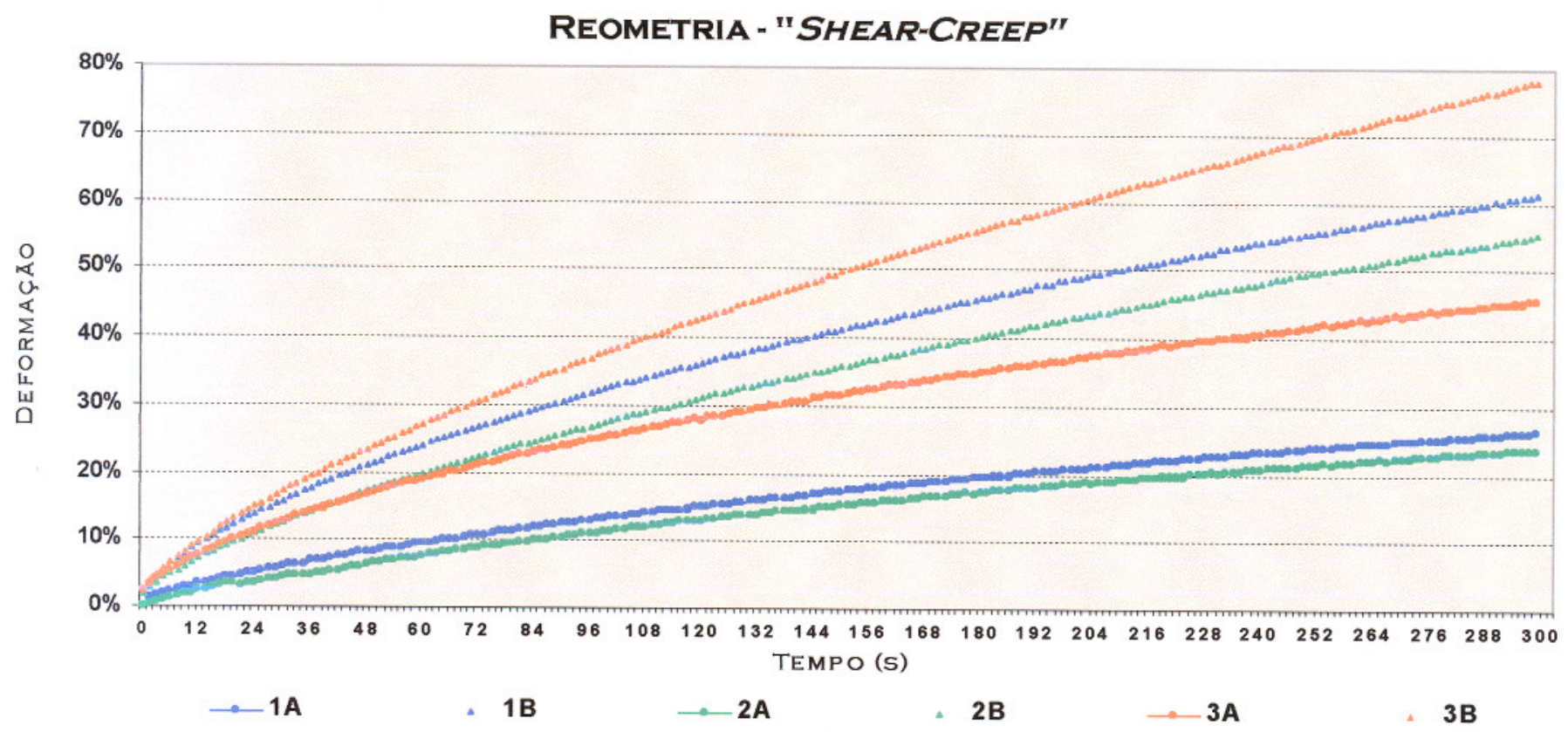

Figura 65 - Gráfico dos ensaios de reometria placa paralela

Na Tabela 15 estão os resultados da máxima deformação apresentada pelos experimentos após 300 s de exposição à tensão cisalhante constante. 
Tabela 15 - Máxima deformação apresentada no ensaio de reometria placa paralela

\begin{tabular}{|c|c|c|c|c|c|c|}
\hline Experimentos & $1 \mathrm{~A}$ & $1 \mathrm{~B}$ & $2 \mathrm{~A}$ & $2 \mathrm{~B}$ & $3 \mathrm{~A}$ & $3 \mathrm{~B}$ \\
\hline $\begin{array}{c}\text { Máxima deformação } \\
\text { após 300s }\end{array}$ & $26 \%$ & $61 \%$ & $24 \%$ & $55 \%$ & $46 \%$ & $78 \%$ \\
\hline
\end{tabular}

A deformação sob cisalhamento é menor para adesivos com alto grau de ligação cruzada (amostras A), pois a presença de uma maior quantidade de ligações cruzadas dificulta o escoamento das cadeias poliméricas. A formulação dois apresentou os melhores resultados sob cisalhamento, tanto para alto nível de reação quanto para baixo, seguida da fórmula um. E, por fim, a formulação três, que contém $5 \mathrm{pcr}$ de resinato de zinco, apresentou os piores resultados de resistência à deformação sob cisalhamento.

\subsection{Cromatografia de permeação em Gel (GPC)}

Cada amostra de adesivo submetida à cromatografia de permeação em gel apresentou um espectro contendo duas distribuições de peso molecular, o primeiro pico (Pico 1) se refere à distribuição da massa molar das cadeias poliméricas maiores (borrachas) e o segundo pico (Pico 2) representa a distribuição molecular dos outros componentes dos adesivos. Como o objetivo deste ensaio foi determinar o tamanho das cadeias das apresentado pelo elastômero com ligações cruzadas, fez-se somente um estudo do primeiro pico (Pico 1). A Figura 66 ilustra um resultado de distribuição de peso molecular contendo os dois picos. 


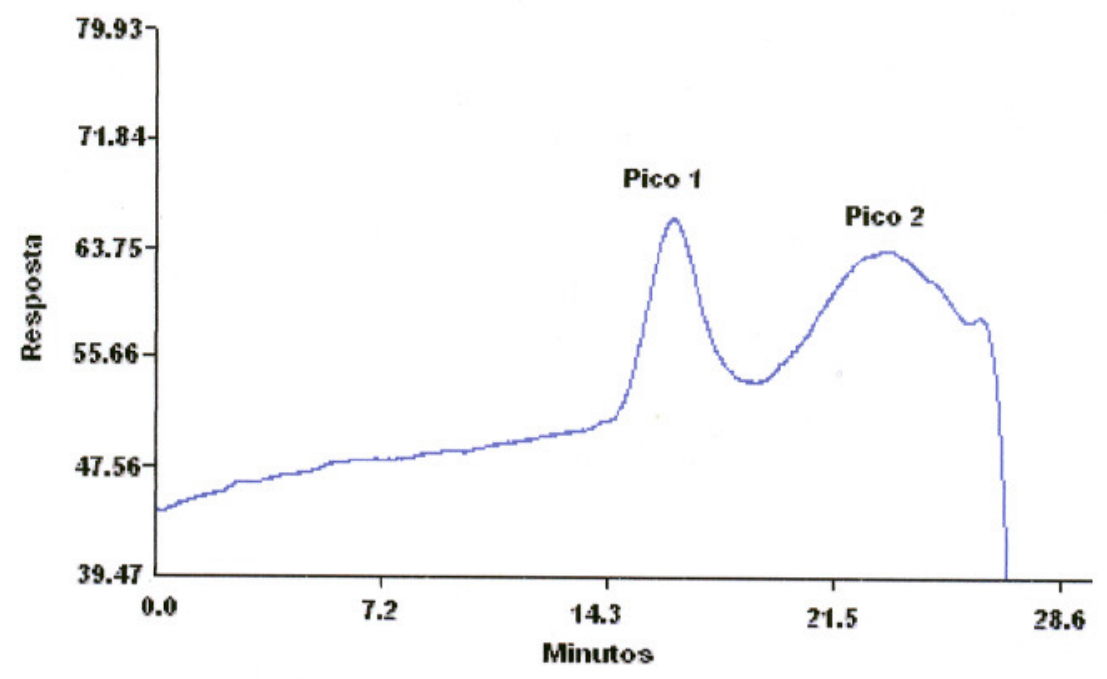

Figura 66 - Exemplo do resultado do GPC

A Figura 67 mostra as curvas obtidas para os seis ensaios realizados com as amostras dos adesivos.

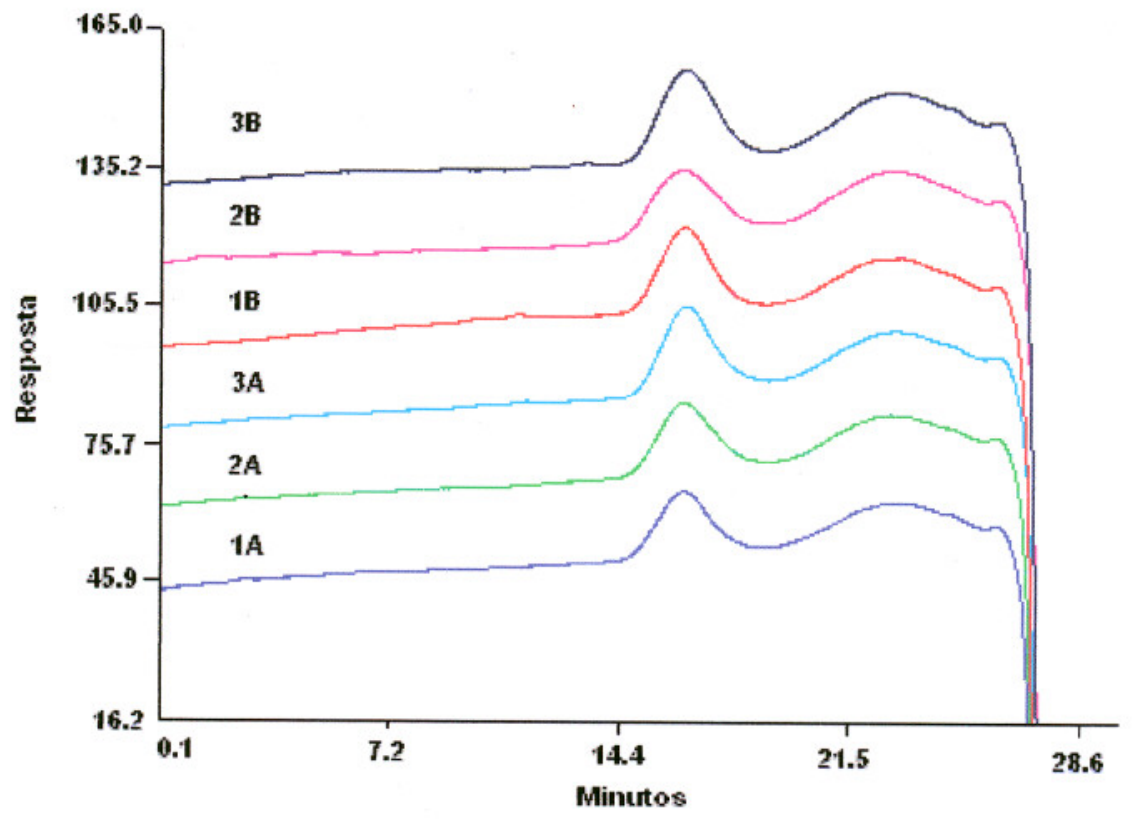

Figura 67 - Gráfico do resultado do GPC para todas as amostras de adesivo 
A Tabela 16 contém o resultado do peso molecular ponderal médio $\left(M_{w}\right)$, peso molecular numérico médio $\left(M_{n}\right)$ e a polidispersividade $(P)$. Onde:

- $M_{w}$ - é sensivel às moléculas de maior massa molar;

- $M_{n}$ - é sensível à concentração das espécies de baixo peso molecular;

- $P=M_{w} / M_{n}$ - é um parâmetro utilizado para determinar a distribuição do peso molecular. Quanto maior a dispersividade mais ramificadas são as cadeias ou o material não tem uma distribuição muito homogênea.

Tabela 16 - Resultado do GPC para todas as amostras de adesivo

\begin{tabular}{|c|c|c|c|c|}
\hline Área & Amostra & $\mathrm{Mw}$ & $\mathrm{Mn}$ & $\mathrm{P}$ \\
\hline Pico 1 & $1 \mathrm{~A}$ & $3,2 \mathrm{E}+05$ & $1,4 \mathrm{E}+05$ & 2,3 \\
\hline Pico 1 & $2 \mathrm{~A}$ & $3,5 \mathrm{E}+05$ & $1,3 \mathrm{E}+05$ & 2,8 \\
\hline Pico 1 & $3 \mathrm{~A}$ & $2,9 \mathrm{E}+05$ & $1,4 \mathrm{E}+05$ & 2,1 \\
\hline Pico 1 & 1B & $2,8 \mathrm{E}+05$ & $1,3 \mathrm{E}+05$ & 2,2 \\
\hline Pico 1 & 2B & $3,0 \mathrm{E}+05$ & $1,6 \mathrm{E}+05$ & 1,9 \\
\hline Pico 1 & 3B & $2,6 \mathrm{E}+05$ & $1,2 \mathrm{E}+05$ & 2,1 \\
\hline
\end{tabular}

Os resultados do peso molecular ponderal médio $\left(\mathrm{M}_{\mathbf{w}}\right)$ foram representados na Figura 68. 


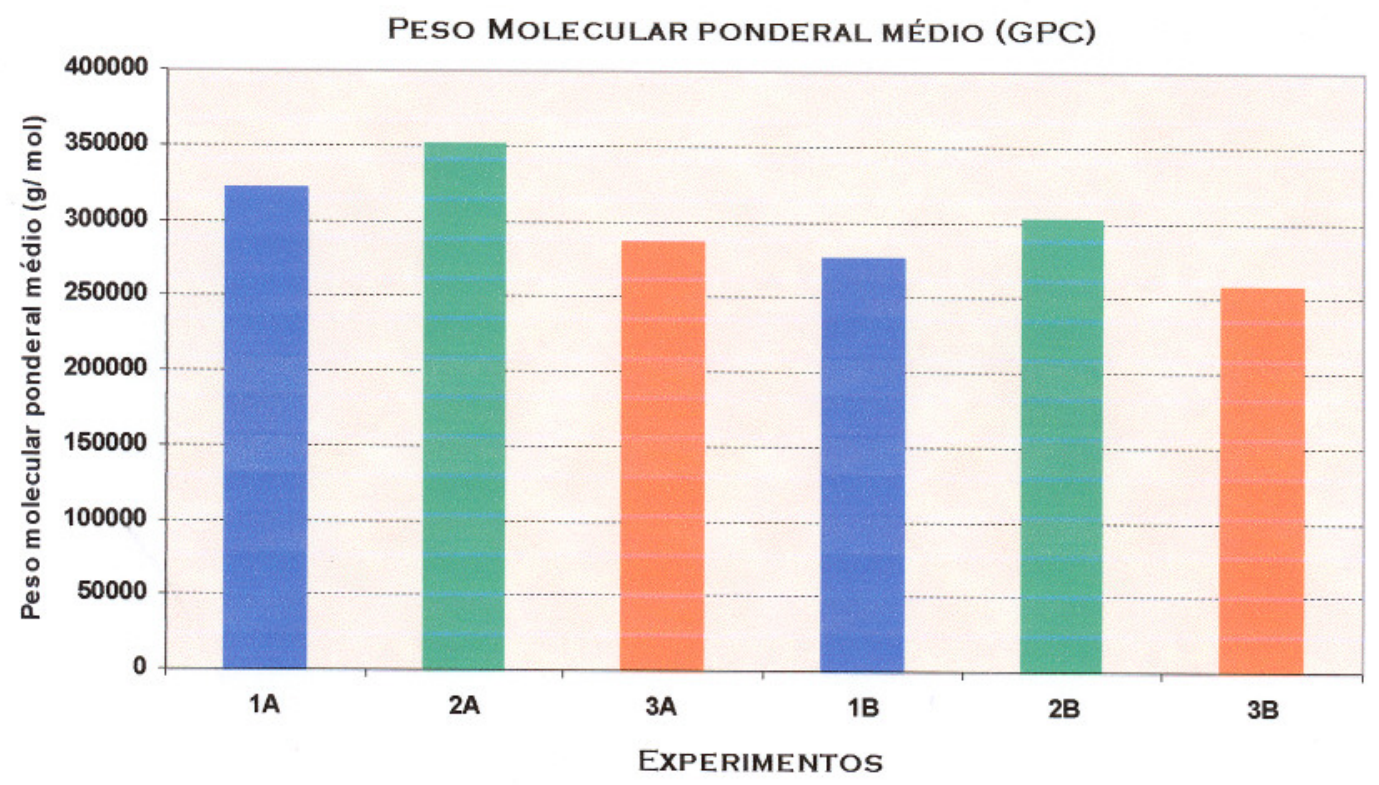

Figura 68 - Gráfico do peso molecular ponderal médio

Percebe-se que as amostras com alto nível de reação $(A)$ apresentaram maior peso molecular ponderal médio, quando comparadas com as amostras de baixo nível de reação, para uma mesma composição, pois a presença de ligações cruzadas aumenta o tamanho das cadeias. A amostra produzida a partir da fórmula dois apresentou maiores pesos moleculares $\left(M_{w}\right)$ quando comparada com as outras composições, para um mesmo nível de reação. Conclui-se que a presença de óxido de zinco na composição favoreceu a formação de ligações cruzadas. A amostra 2A apresentou a maior polidispersividade, devido à grande quantidade de ligações cruzadas. 


\subsection{Espectroscopia no infravermelho com transformada de Fourier} (FTIR).

Os espectros de infravermelho obtidos estão ilustrados na Figura 69, que representa o percentual de transmitância no eixo da abscissa e o número de onda $\left(\mathrm{cm}^{-1}\right)$ no eixo da ordenada.

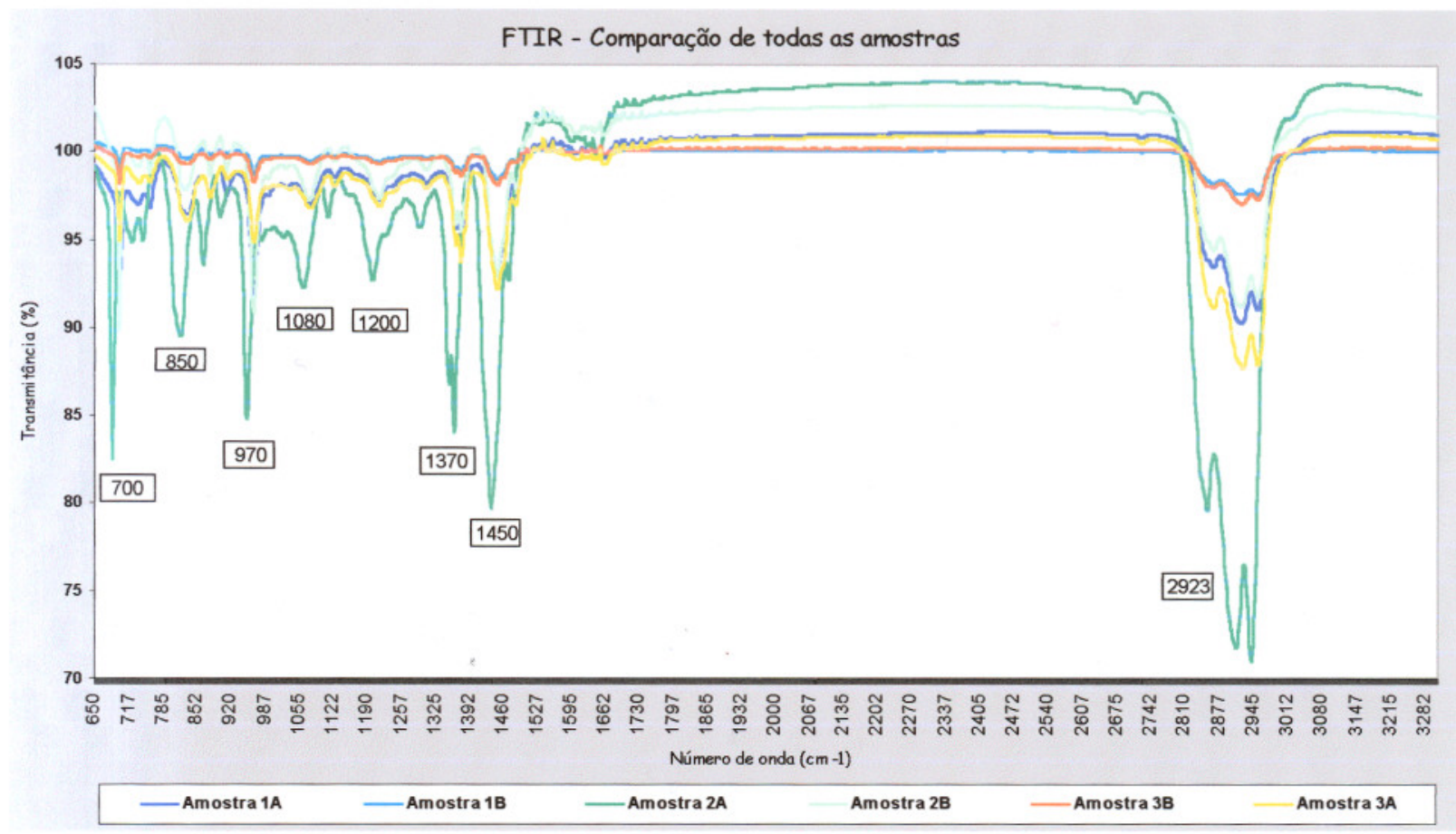

Figura 69 - Gráfico da espectroscopia em infravermelho (FTIR) de todas as amostras

A partir dos dados da Figura 69 conclui-se que todas as amostras apresentaram espectros similares, isto é, com os mesmos picos característicos, os quais estão listados abaixo com seus respectivos grupamentos químicos ${ }^{(18)}$ :

- 700 / 850 - bandas características do grupo $\mathrm{CH}=\mathrm{CH}$ cis, presentes na composição dos elastômeros utilizados; 
- $950 / 1080 / 1200$ - bandas características do grupo $\mathrm{CH}=\mathrm{CH}$ trans, também presentes na composição dos elastômeros;

- 1370 - banda característica do grupo fenol, com presença de $\mathrm{CH}_{3}, \mathrm{CO}$ e $\mathrm{OH}$;

- 1450 - banda característica dos grupos $\mathrm{CH}_{2}$ e $\mathrm{CH}$, presentes na composição dos tatificantes e nos elastômeros utilizados;

- 2923 - banda característica do grupo $\mathrm{CH}$, presente em quase todos os componentes.

Entretanto, fez-se uma análise mais aprofundada para verificar se há diferenças significativas entre os espectros obtidos. Primeiramente foi necessária a realização de uma normalização dos espectros, pois há diferenças nas intensidades devido à quantidade de amostra ensaiada. Para tal foi calculada a área do pico referente ao grupo fenol $(1370 \mathrm{~cm}-1)$, utilizando o software GRAMS/386 conforme Figura 70 , que foi usada como valor para normalização, pois a quantidade de resina fenólica é a mesma para todas as fórmulas. Em seguida, calculou-se a somatória das áreas referentes às ligações duplas cis e trans do carbono $(700,850,950,1080$ e $1200 \mathrm{~cm}-1)$. A soma desses valores foi dividida pelo valor da área representada pelo grupo fenol, obtendo assim os dados de ligações duplas normalizados em relação ao grupo fenol. Dessa maneira foi possível determinar a quantidade de ligações duplas presentes em uma mesma fórmula para diferentes condições de reação (alta e baixa). 


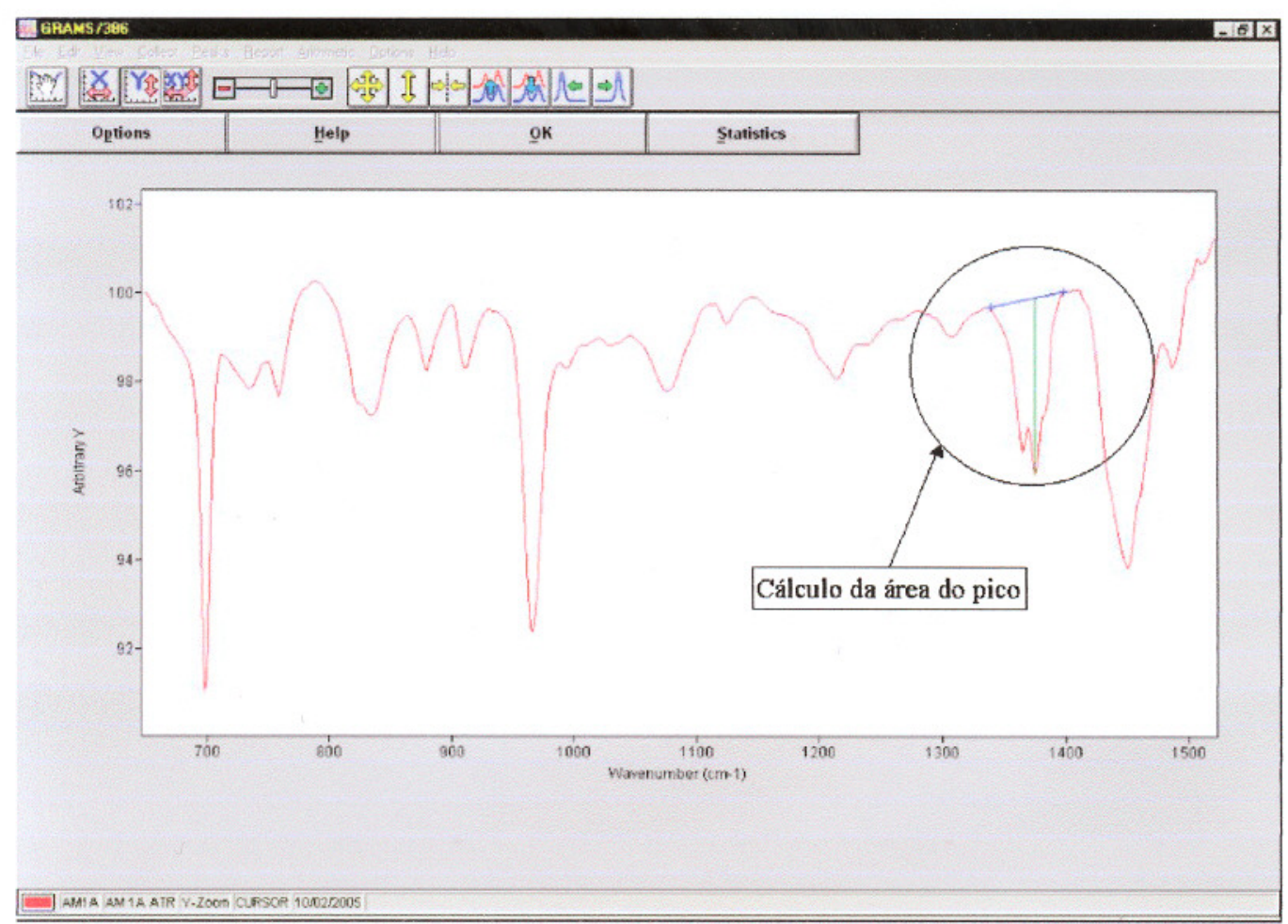

Figura 70 - Ilustração do cálculo da área de um pico do espectro de infravermelho

Os dados da Tabela 17 mostram que para todas as fórmulas a condição de alta reação (A) apresenta menores índices de ligações duplas, pois elas foram rompidas para permitir a formação de ligação cruzada. Logo, a relação da quantidade normalizada de ligações duplas do carbono entre a amostra B e A é maior do que 1, para todos os casos.

Tabela 17 - Resultado da normalização das áreas dos picos de FTIR analisados

\begin{tabular}{|c|c|c|c|c|c|c|c|}
\hline \multicolumn{8}{|c|}{ DADOS RELATIVOS A ÁREA DOS PICOS ANALISADOS (CM-1 $\mathrm{x} \%$ ) } \\
\hline $\begin{array}{l}\text { Número de ondas } \\
(\mathrm{cm}-1)\end{array}$ & $\begin{array}{l}\text { Grupo químico } \\
\text { característico }\end{array}$ & $1 \mathrm{~A}$ & 1B & $2 \mathrm{~A}$ & $2 B$ & $3 A$ & 3B \\
\hline 1370 & Grupo fenol & 104,8 & 25,4 & 35,6 & 108,1 & 30,3 & 126,1 \\
\hline 700 & Grupo $\mathrm{CH}=\mathrm{CH}$ cis & 64,9 & 13,4 & 15,2 & 66,3 & 18,2 & 39,1 \\
\hline 850 & Grupo $\mathrm{CH}=\mathrm{CH}$ cis & 19,4 & 6,2 & 7,4 & 21,3 & 5,9 & 23,5 \\
\hline 950 & Grupo $\mathrm{CH}=\mathrm{CH}$ trans & 105,9 & 18,1 & 12,2 & 62,3 & 4,1 & 58,2 \\
\hline 1080 & Grupo $\mathrm{CH}=\mathrm{CH}$ trans & 46,9 & 11,6 & 9,8 & 51,2 & 11,0 & 44,1 \\
\hline 1200 & Grupo $\mathrm{CH}=\mathrm{CH}$ trans & 20,5 & 21,5 & 19,3 & 20,3 & 6,0 & 87,0 \\
\hline & $\begin{array}{l}\text { Somatória das áreas relativas à } \mathrm{CH}=\mathrm{CH} \\
\text { (cis e trans) }\end{array}$ & 257,6 & 70,8 & 63,9 & 221,4 & 45,2 & 251,9 \\
\hline & $\begin{array}{c}\begin{array}{c}\text { Dados normalizados em relação ao grupo } \\
\text { fenol }\end{array} \\
\end{array}$ & 2,5 & 2,8 & 1,8 & 2,0 & 1,5 & 2,0 \\
\hline & Relação entre amostra $\mathrm{B} \mathrm{e} \mathrm{A}$ & \multicolumn{2}{|c|}{1,13} & \multicolumn{2}{|c|}{1,14} & \multicolumn{2}{|c|}{1,34} \\
\hline
\end{tabular}


Conclui-se que a quantidade de ligação cruzada não altera a composição química do produto, apenas modifica a ramificação e o peso molecular, conforme exposto no item 4.2.8 (Cromatografia de permeação em Gel) e verificado neste ensaio através da alteração da quantidade de ligações duplas de carbono. O metal Zinco presente nas fórmulas dois e três não foi detectado, pois a quantidade adicionada era muito pequena.

\subsection{Estrutura química}

Os adesivos estudados neste trabalho são formados por uma mistura de materiais que estão dispersos em um líquido comum, o solvente. Porém, as borrachas e o fenol sofreram modificações em suas estruturas químicas, já os outros materiais permaneceram da mesma maneira que foram adicionados. A alteração ocorrida na estrutura das borrachas foi o rompimento da dupla ligação para permitir a formação da ligação cruzada. Esse mecanismo ocorreu com maior freqüência e intensidade nos experimentos que apresentaram maior nível de reação (amostras 1A, 2A e 3A), conforme resultados encontrados no item 4.5 - Grau de ligação cruzada. A Figura 71 ilustra esse mecanismo para a borracha natural (por exemplo). 

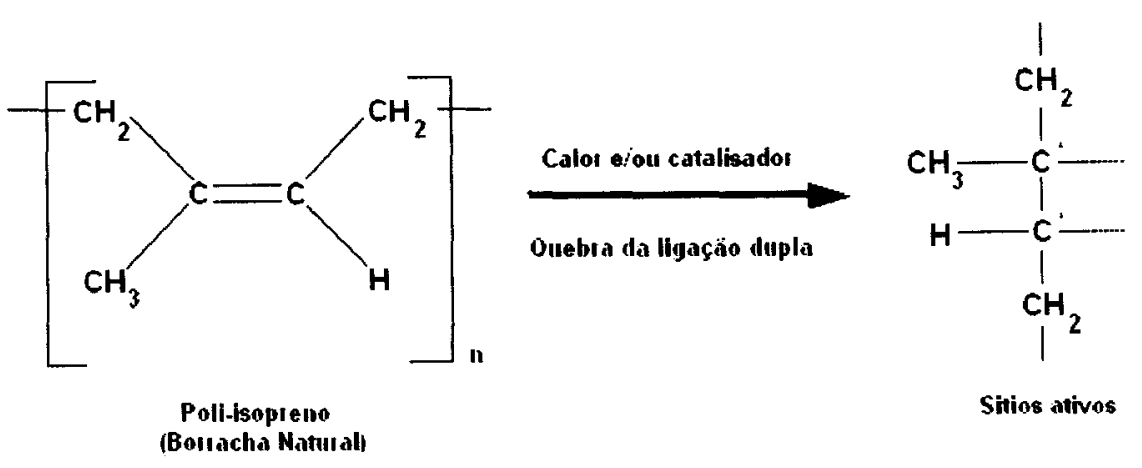

Sitios ativos

Figura 71 - llustração do rompimento da ligação dupla da borracha natural

Esse mecanismo ocorreu devido à aproximação do grupo fenol e a presença de calor. Pode-se também concluir que a presença do óxido $\mathrm{ZnO}$ catalisa esse fenômeno, isto é, o óxido facilita o rompimento desta ligação. Isto explica a maior quantidade de ligações cruzadas na fórmula dois.

O rompimento da ligação dupla do elastômero permite a formação da ligação cruzada com o grupo fenol, conforme Figura 72.<smiles>[R]C1([R])CC(CC(C)(CC(C)(C)C(C)(C)C)C(O)C(C)(C)C(C)(C)C)OC([R])([R])C1([R])[R]</smiles>

Ligaçäo crızada ocorrida a partir da quebra da ligaçäo dupla da borracha onde a define o tanxanho da ligaçáo cruzarda

Figura 72 - llustração da estrutura química da borracha com ligação cruzada

Os radicais $R$ vão depender do elastômero utilizado. Para o caso da borracha natural os radicais são: 
- $\mathrm{R} 1=\mathrm{CH}_{2}$

- $\mathrm{R} 2=\mathrm{CH}_{3}$

- $\mathrm{R} 3=\mathrm{H}$

- $\mathrm{R} 4=\mathrm{CH}_{2}$ 
O trabalho desenvolvido nesta dissertação de mestrado possibilitou a obtenção de um conjunto de métodos de caracterização de adesivos PSA, os quais foram fundamentais para eleger o melhor produto criado em escala de laboratório. Poucos estudos foram encontrados na literatura sobre a caracterização de adesivos sensíveis à pressão com a finalidade de fabricação de produtos aplicados em laminados ou fitas flexíveis de PVC.

O método utilizado para escolher a melhor amostra produzida em laboratório foi: listar todos os ensaios realizados e, para cada um deles, eleger as três amostras que apresentaram os melhores resultados julgados. Então, o adesivo que obteve a maior pontuação foi eleito como o de melhor performance para o conjunto de características avaliadas. $\mathrm{O}$ objetivo principal deste estudo foi verificar quais fórmulas e condições superaram as propriedades da referência (fórmula um). Na Tabela 18 é possível analisar os melhores adesivos obtidos em função de cada propriedade. 


\begin{tabular}{|c|c|c|c|c|c|c|c|}
\hline \multicolumn{7}{|c|}{ Resumo do melhor desempenho } & $\mathbf{1 A}$ \\
\hline & Propriedadel Experimento & $\mathbf{2}$ & $\mathbf{3 A}$ & $\mathbf{1 B}$ & $\mathbf{2 B}$ & $\mathbf{3 B}$ \\
\hline 1 & Adesão em superficie metálica sem exposição ao calor & & $\mathbf{x}$ & & & $\mathbf{x}$ & $\mathbf{x}$ \\
\hline 2 & Adesão em superficie metálica com exposição ao calor & & $\mathbf{x}$ & $\mathbf{x}$ & & & $\mathbf{x}$ \\
\hline 3 & Adesão em substrato vinilico sem exposição ao calor & & $\mathbf{x}$ & & & $\mathbf{x}$ & $\mathbf{x}$ \\
\hline 4 & Adesão em substrato vinilico com exposição ao calor & & $\mathbf{x}$ & $\mathbf{x}$ & & & $\mathbf{x}$ \\
\hline 5 & Ancoragem sem exposição ao calor & & & & $\mathbf{x}$ & $\mathbf{x}$ & $\mathbf{x}$ \\
\hline 6 & Ancoragem com exposição ao calor & & $\mathbf{x}$ & & & $\mathbf{x}$ & $\mathbf{x}$ \\
\hline 7 & Queda de ancoragem & & $\mathbf{x}$ & $\mathbf{x}$ & & & $\mathbf{x}$ \\
\hline 8 & Resistência ao cisalhamento & $\mathbf{x}$ & $\mathbf{x}$ & $\mathbf{x}$ & & & \\
\hline 9 & Grau de ligaçōes cruzadas & & $\mathbf{x}$ & $\mathbf{x}$ & & $\mathbf{x}$ & \\
\hline 10 & Fluência sob cisalhamento & $\mathbf{x}$ & $\mathbf{x}$ & $\mathbf{x}$ & & & \\
\hline 11 & Peso molecular ponderal médio & $\mathbf{x}$ & $\mathbf{x}$ & & & $\mathbf{x}$ & \\
\hline
\end{tabular}

Tabela 18 - Resumo do melhor desempenho dos adesivos analisados.

Para as amostras preparadas a partir de um processo de alto nível de reação conclui-se que a fórmula três apresentou propriedades superiores à referência, e a fórmula dois foi superior às duas (referência e a fórmula três). Para a condição de baixo nível de reação, as duas fórmulas alteradas (dois e três) foram superiores à referência, sendo que a fórmula três apresentou uma pequena vantagem nas propriedades avaliadas.

A adição do resinato de zinco (representada pela fórmula três) conferiu uma pequena melhoria nas propriedades finais do adesivo quando comparadas com a referência (fórmula um). O zinco metálico, utilizado na forma de compósito juntamente com o breu, desenvolveu um melhor poder de adesão e ancoragem para a amostra de baixo nível de reação. Isto ocorreu devido ao fato de o breu atuar como um tatificante, conforme literatura consultada ${ }^{(10)}$. Para a condição de alto nível de reação se observou uma grande quantidade de ligações cruzadas, quando comparada com a referência, pois o zinco, 
mesmo na forma de composto, foi capaz de desenvolver um grande poder de catalisador. Entretanto, as propriedades de adesão e ancoragem foram prejudicadas em relação à mesma fórmula com baixo nivel de reação.

A adição do óxido de zinco (representada pela fórmula dois) conferiu uma grande melhoria nas propriedades finais do adesivo quando comparadas com a referência (fórmula um) para alto nível de reação. Para a condição de baixo nivel de reação a fórmula dois apresentou uma melhora em relação à referência, porém a falta de coesão, evidenciada no ensaio de adesão ao dorso vinílico, compromete a aplicação desse adesivo.

Dentre todas as análises realizadas pode-se concluir que a melhor composição e o melhor processamento se deram para a condição $2 \mathrm{~A}$ : composição com adição de 5 pcr de óxido de zinco e alto nível de reação durante o processamento. A adição do óxido de zinco fez com que o rompimento da ligação dupla das borrachas fosse favorecido, como conseqüência, maior foi o número de ligações cruzadas formadas. Este resultado foi comprovado no ensaio que determina o grau de ligações cruzadas (item 4.5) e maior foi o peso molecular do composto elastomérico formado, conforme resultado obtido através da técnica de GPC. Todo esse conjunto de modificações favoreceu para que a fórmula dois com alto nivel de reação apresentasse os melhores resultados de performance para as propriedades avaliadas. Esse resultado pode ser replicado para produção em escala industrial, trazendo melhores resultados de resistência a cisalhamento, quando comparados com a referência.

Finalmente, conclui-se que a adição de óxido de zinco metálico, aliada a um alto nivel de reação, confere um incremento na resistência ao cisalhamento 
do adesivo (em relação à fórmula referência), principal característica de interesse neste estudo. A adição de resinato de zinco resulta em melhores condições de aderência e ancoragem, para baixo nível de reação, porém, não se obtém esse benefício para o alto nível de reação. Segundo a literatura ${ }^{(10)}$, esses dois materiais ( $\mathrm{ZnO}$ e resinato de zinco) adicionados nas fórmulas 2 e 3 são considerados aceleradores da reação de cura, isto é, o elemento zinco atua como catalisador durante a formação da ligação cruzada do grupo fenol com as cadeias elastoméricas. Porém, o poder de catálise vai depender das condições de processamento e das formulações utilizadas.

Após esse estudo, conclui-se que um maior tempo de exposição do adesivo ao calor, durante o processamento, favorece a formação de ligações cruzadas, conforme verificado nos ensaios de grau de ligações cruzadas (item 4.5), GPC (item 4.8) e FTIR (item 4.9). As amostras reagidas durante 60 minutos (1A, 2A e $3 A)$ apresentaram maiores quantidades de ligações cruzadas que as amostras submetidas à reação durante $\mathbf{3 0}$ minutos. Porém, segundo a literatura consultada ${ }^{(10)}$, tempos muito prolongados de reação levam à formação de pontos de gel, que contêm um grau excessivo de ligação cruzada. Isto torna o material insolúvel em solvente (devido à alta concentração de ligações cruzadas) e sem aderência. Nestes experimentos não foram identificados pontos de gel. Logo, em um próximo estudo, pode-se estender o tempo de reação (acima de 60 minutos) até encontrar o limite de reação para cada fórmula que não prejudique as propriedades de aderência. 
Como sugestão para continuidade deste trabalho, destacam-se os seguintes estudos futuros:

- Avaliar diferentes concentrações de óxido de zinco;

- Verificar o efeito causado nas ligações cruzadas para quantidades diferentes de resina fenólica;

- Testar diferentes borrachas sintéticas;

- Avaliar o efeito da concentração e o tipo de resinas tatificantes;

- Avaliar tempos maiores de reação.

- Verificar o efeito na capacidade de aderência devido a um aumento da quantidade de ligações cruzadas. 


\section{REFERÊNCIAS BIBLIOGRÁFICAS}

1- CAGLE, C.V., "Adhesive Bonding, techniques and applications", McGraw-Hill, New York 1968.

2- http://www quimica com br/revista

3- DREW, R. G. U.S. Patent 1,760,820 (1930)

4- LANDROCK, A. H. U.S.A., "Adhesives Technology Handbook".

5- HOFMANN, W. U.S.A. "Rubber Technology Handbook", (1996)

6- CRAWFORD, R.J., "British Plastics Engineering”, (1998), $3^{\circ}$ Edição

7- http://www rubberstudy.com/statistics. aspx

8- WETZEL, F. H., "Rubber Age 82", (1957)

9- WETZEL, F. H., and ALEXANDER, B. B., “Adhesives Age”, (1964)

10- SATAS, D., "Handbook of Pressure Sensitive Adhesives", Van Nostrand Reinhold, 1989, $2^{\circ}$ Edição

11- BILLMEYER J.R., F.W. "Textbook of Polymer Science", John Wiley \& Sons, 1984

12- VERNERET, H. "Solventes Industriais", Toledo Assessoria Editorial, 1984.

13-HAGE, E. JR., "Compósitos e blendas poliméricas", Instituto Latino Americano de Tecnologia, 1989.

14- CONSIDINE, D.M., "Chemical and process technology ecyclopedia", MacGraw-Hill, 1974

15- Bruno, E.J., "Types of adhesives, adhesives in modern manufacturing". Published by Society of Manufacturing Engineers (SME), 1970.

16- LEVINE, I. W. U.S. Patent 1,573,978 (1926) 
17-http://www hiq.aga com.br

18- POUCHERT, C.J., "The Aldrich Library on Infrared Spectra", 2 Edição, 1975

19- Material didático de treinamento interno da 3M do Brasil - Metodologia Seis Sigma, DMAIC para Green Belts.

20- http://www.specialchem4adhesives.com

21-SHECUT, W. H., and DAY, H.H. U.S. Patent 3,965 (1845)

22- http://www.intad asn au/materials (Industrial Technology and Design Teachers Association).

23- http://www.comciencia.br/

24- JOHNSTON, J., “Adhesives Age”, p. 20-26, New York 1968. 


\section{GLOSSÁRIO}

Elastômero - são polímeros lineares de alto peso molecular, ao quais, geralmente, permite-se a formação de ligações cruzadas para eliminar o escorregamento intermolecular. São estirados facilmente com baixas tensões e sofrem grandes elongações (em torno de 600\%) com reversão.

Nanociência - estudo e pesquisa de nível atômico, molecular e macromolecular, na escala de 0,1 a 100 nanômetros, que tem como objetivo proporcionar a compreensão de fenômenos na escala de nano e criar materiais que tenham propriedades e funções únicas devido ao seu tamanho reduzido.

Nanotecnologia - é a aplicação da nanociência na síntese desses materiais ideais com alta precisão, na caracterização e análise para que todas as propriedades intrínsecas sejam conhecidas e ainda na manipulação dos nanoobjetos obtidos.

Massa molar - durante os processos de polimerização, nem todos os monômeros são transformados em cadeias poliméricas longas, logo existe uma variação de comprimento de cadeias chamado de distribuição de peso molecular.

Polimerização - sintese de polimeros a partir de monômeros 
Temperatura de transição vítrea $(\mathrm{Tg})$ - é conhecida como a temperatura de transição entre o estado rígido e elástico, ou transição de segunda ordem. É a temperatura a partir da qual as cadeias poliméricas exibem movimentação.

Termofixos - são materiais que se tornam permanentemente duros quando aquecidos e não fundem caso sejam expostos ao calor novamente. Durante o primeiro aquecimento formam ligações cruzadas entre as cadeias poliméricas adjacentes.

Termoplástico - são materiais poliméricos que amolecem ou se liquefazem com a presença de calor e solidificam quando resfriados. Podem repetir essas mudanças por várias vezes.

Terebintina - designação comum das resinas que se extraem de plantas da classe Terebinthales (botânica). 